University of Rhode Island

DigitalCommons@URI

Open Access Dissertations

2017

\title{
Writing Irish America: Communal Memory and the Narrative of Nation in Diaspora
}

\author{
Beth O'Leary Anish \\ University of Rhode Island, banish@charter.net
}

Follow this and additional works at: https://digitalcommons.uri.edu/oa_diss

\section{Recommended Citation}

Anish, Beth O'Leary, "Writing Irish America: Communal Memory and the Narrative of Nation in Diaspora" (2017). Open Access Dissertations. Paper 598.

https://digitalcommons.uri.edu/oa_diss/598

This Dissertation is brought to you for free and open access by DigitalCommons@URI. It has been accepted for inclusion in Open Access Dissertations by an authorized administrator of DigitalCommons@URI. For more information, please contact digitalcommons-group@uri.edu. 
WRITING IRISH AMERICA: COMMUNAL MEMORY

AND THE NARRATIVE OF NATION IN DIASPORA

BY

BETH O’LEARY ANISH

A DISSERTATION SUBMITTED IN PARTIAL FULFILLMENT OF THE

REQUIREMENTS FOR THE DEGREE OF

DOCTOR OF PHILOSOPHY

IN

ENGLISH

UNIVERSITY OF RHODE ISLAND 


\title{
DOCTOR OF PHILOSOPHY DISSERTATION
}

OF

\author{
BETH O’LEARY ANISH
}

APPROVED:

Dissertation Committee:

Major Professor $\quad$ Ryan Trimm

Naomi Mandel

Scott Molloy

Nasser H. Zawia

DEAN OF THE GRADUATE SCHOOL

UNIVERSITY OF RHODE ISLAND

2017 


\begin{abstract}
In this project I trace Irish ethnic identity formation in the United States and the creation of the Irish-American narrative throughout the twentieth century as reflected in Irish-American life-writing - autobiographical or at least semi-autobiographical fiction and memoir - from just after World War II to the early 2000s. All of the works included in this study examine in some way the question of what it means to be Irish in America. The authors in this study collectively show how an Irish identity was given up in America and eventually pieced back together again. Some of the original elements remained, but others were forgotten, misunderstood, or invented. The IrishAmerican narrative tells of a rise from poverty and oppression to American comfort and respectability. There is pride in this rise, but there is also loss. I argue that symbol has replaced substance in popular representations of the Irish in America, and that imagination has been used to create an Irish-American identity that attempts to soothe the pain of what has been lost.

To think through these works in terms of ethnic identity formation, I employ theories of home and nation, applying those concepts to a people in diaspora and how they see themselves in relation to two different homes, the one they left behind but that still informs their identity, and the one in which they live and raise their families. In the early twentieth century, the way Irish Americans see themselves against a dominant Anglo-Protestant culture can be traced back to the colonial setting they have left. For this reason I apply some tenets of postcolonial theory to this American literature of a displaced Irish population. This move from one homeland to another, especially when forced by poverty rather than a desire to leave, does not come without
\end{abstract}


trauma. As such, I also employ theories of individual trauma and trauma as it is passed down the generations. The theory of ethnic identity formation as an ongoing process is also useful to understand how the Irish understand themselves in America. Finally, what makes it into a national or diasporic narrative has at least as much to do with what is forgotten as what is remembered in the name of presenting a unified whole. I use theories of cultural memory and forgetting to understand the fractured nature of the Irish-American story that is passed on, and the gaps and fissures found therein. 


\section{ACKNOWLEDGMENTS}

I would first like to thank Ryan Trimm for his guidance through this project. His suggestions for theoretical readings provide the underpinnings for much of the work I do related to postcolonialism, nation, home, and memory. I am thankful, too, that Naomi Mandel agreed to join my committee. She added the much-needed perspective of ethnic identity formation in the United States, as well as transgenerational trauma. Detailed feedback on my chapters from both Ryan and Naomi has led to a more focused and well-supported argument. To Scott Molloy for his expertise on Edward McSorley's Our Own Kind, and the position of the Irish in America in the twentieth century, I also owe my gratitude. Finally, I could not have started this project without Eve Sterne's reading list on Irish-American history. Thanks as well go to Michelle Caraccia for helping me navigate the dissertation process at URI.

My education on Irish Studies has happened outside the bounds of any one university. I am forever grateful to Phil O'Leary, a mentor since my undergraduate days at Boston College, for still responding to my e-mails after all of these years, and for sharing his wisdom, humor, and vast knowledge. I came into this project with an idea on the symbolic nature of Irish-American identity at the end of the twentieth century, and the seemingly contradictory idea that Irish Americans still consider Ireland home. Both of those ideas came from Michael Patrick MacDonald's memoirs of growing up in South Boston, so I am thankful for his writing and correspondence. Those ideas flourished in the presence of my colleagues in the American Conference for Irish Studies (ACIS), many of whom have become friends. Parts of all of these chapters were previewed and refined at ACIS conferences. Thanks go to Jim Rogers 
for his mentorship, and his suggestion that I look at Elizabeth Cullinan's work. Chapter 3 would not have happened without Jim's input. I cannot forget the brilliant group of ACIS women with whom I have been fortunate enough to surround myself: Mary Kelly, Eileen Moore Quinn, Kelly Matthews, Áine Greaney, Ellen Scheible, Meg Carroll, Jeanne Lakatos, Catherine Shannon, Suzanne Buckley, Rachel Lynch, Mary Burke, who first invited me to the New England ACIS conference at UConn, and most recently Celeste Ray. Their conversations, reading suggestions, many laughs, and constant support and encouragement have been invaluable.

Constant support and encouragement has been a theme throughout my life, starting on day one from my parents Bob and Rita O'Leary. For my father education was second only to faith in his priorities for us growing up. Both he and my mother taught me what it means to be a life-long learner. Like them I will never be done learning, although I am glad to see this leg of the journey come to an end while my father is still "an earth creature" to witness it, as per his request. My mother, my greatest cheerleader and role model, may have had her speech limited recently but never her love. I have six living siblings and one guardian angel sister who have always shown me how proud they were of what I accomplished. They are all rooting for me still. The same goes for two friends who are like sisters, Michelle and Lynn. I am grateful to them all.

Finally, to the little family I helped create, my husband Ron and our children Maura and Brendan, I need to express my deepest thanks for their patience while I undertook this project that so often took me away from them in mind and body. That they have been behind me the whole time means the world to me. 


\section{DEDICATION}

For Maura and Brendan, the next generation of my Irish-American story. 


\section{PREFACE}

\section{The Personal Becomes Academic: Grandpa O'Leary's “O” and the Loss of Connection to Ireland}

This dissertation is the culmination of a lifelong interest and passion. I cannot recall a time when I was not somehow invested in my Irish ancestry and learning more about Ireland. My elementary school was Gates Lane, and our mascot was the Gators, making green our school color. That was a happy coincidence when I was able to get my first green Gates Lane jacket, the perfect outerwear for my home city of Worcester's Saint Patrick's Day parade. I wore that jacket to the parade as long as I could squeeze into it, always with my "Kiss Me, I'm Irish” button attached. I also recall a family tree project in my $5^{\text {th }}$ grade Social Studies class when my Grandma Ferris was still around to ask about her ancestors. I gained attention from the teacher because I could trace both sides of my family back to Ireland. Few of my fellow students could go so far back. In high school my Advanced Placement English and U.S. History research projects on Joyce's Portrait of the Artist as a Young Man and Irish contributions to the United States allowed me to begin my academic study of Ireland and Irish America. These were followed quickly by my enrollment as an undergraduate at Boston College because of the university's Irish roots, and my subsequent passion for the Irish Studies courses offered there. Through all those years I never stopped to ask why my Irish heritage was so important to me. The questions of the fraught relationship between home and diaspora I am attempting to answer for the literature I have chosen here in this dissertation may just possibly answer some similar questions for me and for my family. 
A brief look back through four branches of my family shows just how diverse the experience of the Irish in America could be: from early arrivals of the 1820s who quickly established themselves and fought to establish their church, to later arrivals of the 1880s whose children thrived as Americans in their already-established communities, to that large wave of Famine immigrants in the middle who were looked down upon for their poverty and their non-Yankee ways, and whose specific roots in Ireland were lost to their desperate circumstances and the crush of trying to survive once they arrived here. From men who were shoemakers and mill workers, to women who raised large families of new Americans in trying circumstances. From different counties all over Ireland, to different locations all over the United States. From those who worshipped daily at the pub to those who worshipped daily at the altars of churches they established. There is clearly no one Irish-American experience. The degree to which immigrants and their descendants looked back to Ireland varied as much as the individuals and the situations in which they found themselves. Still, they all have the commonality of having given up Ireland or, from the perspective of many, of having had it taken away. Just how that loss translated into American lives is the subject of my academic work as well as my lifelong personal interest. What was retained and what was lost of Irishness in America—in other words what was remembered and forgotten - is the subject of this dissertation.

Growing up in 1970s and 1980s Worcester, Massachusetts, my maiden name (O'Leary) always brought a smile to people's faces and some positive comment about being Irish. Being Irish in the Northeastern United States at that time was membership in a very large, very proud club. The tough years of overt prejudice were well behind 
us, the ascent made official through the election of JFK over a decade before my birth. I was proud to say that my Grandfather Dennis O'Leary was born in Castleisland in County Kerry, Ireland, when most of my peers' families were several generations in America. The truth was my grandfather was brought here by his parents as a toddler, so he would be considered more of a 1.5 generation in the parlance of American immigration history. He would have had no memory of Ireland, and even if he did I never met him to speak of it, for he died twenty years before I was born. That I never knew my closest Irish ancestor personally, and that even he had little if any of his own memories of Ireland, are just some of the many gaps in my family's Irish history. In this I am not unlike most Irish Americans, who feel a connection with a country that many have never seen, and with a story of their Irish ancestors that is as fractured as it is whole.

What I do know about my Grandpa O’Leary is he grew up playing baseball and American football. He turned down a baseball scholarship to the College of the Holy Cross so he could start earning money for his family. He learned a trade (pipe fitting) and became a factory worker and a landlord of some of Worcester's famous three-decker apartment buildings. He married a woman from a long-established Worcester Irish family. He managed his money well enough to buy land both in the city of Worcester and in the rural areas around it. In the rural areas he tried his hand at raising chickens and goats. He and his wife put their six children through Catholic elementary and high schools, and the three who wanted to go, through college. One became a nun and the rest, all boys, married nice Catholic girls. In true mid-twentieth century American fashion, their wives were Italian, Polish, and Irish; it was their 
Catholicism that mattered most to their future in-laws. If the O'Leary boys did not go to college they served proudly in the American military during World War II and the Korean War, and then entered trades. The college-educated ones became teachers. Except for the nun, all of the siblings had between four and eight children. They were fruitful and multiplied during the Baby Boom years.

My grandfather was an American success story, but there is evidence that he did not forget his Irish roots. In fact, without him my maiden name would not have been so glaringly Irish, for it was he who rescued the "O" his father had left off when he came to this country. According to family story, when he came of age, Grandpa went to city hall in Worcester and restored the "O" to O'Leary. That to me is an act of pride in his heritage, an act of not wanting to blend in completely to Anglo-American whiteness. At this I have to guess, however, because he is not here to speak for himself. I only recently heard the story from my aunt, as my father has no recollection of it. What one sibling remembers and another forgets on the familial level has implications for what is retained and forgotten on the communal level. These are gaps and fissures in our story that we fill in with imagination and (more or less) educated guesses.

Another family story is that my father was set to be named Robert Emmet, after the Irish nationalist hero who famously declared before being put to death that no epitaph should be written on his tomb until Ireland was free. My grandmother, fearing that he would face prejudice, insisted his middle name be Edward. Thus Robert Edward O'Leary was born in 1922, the same year that most of Ireland gained its independence from Great Britain. The coincidence of my father's year of birth with 
the birth of the Irish Free State was never once mentioned, or probably even thought of, in our house growing up. Quite honestly the first time I thought of it was in writing this preface, after decades of studying Irish history and literature. Yet my grandfather must have been conscious of what was happening in Ireland. The stories of both my father's last and middle names make me think that his father probably followed the news of his native country from Massachusetts as so many others did.

There is another side to my Grandfather O'Leary's immigrant success story. My father's paternal grandmother, also a native of County Kerry, is said to have been quiet and cross, and probably depressed. She barely spoke to her grandchildren. Did she not want to leave her homeland? Did she have a choice in the matter? Who did she leave behind? My aunt the nun tells me that her O'Leary grandparents spoke Irish to one another when they did not want the children to know what they were saying, yet three generations later I hardly knew about this language I heard called "Gaelic" as a child. The language had been lost to us. But what other losses was Sarah Moriarty O'Leary mourning? It is only as a scholar of Irish-American literature that I am beginning to figure that out. Again, though, there is a gap I cannot bridge because my paternal great grandmother was gone long before I was born, as was her son. I can only make historical generalizations, and even those are suspect because lives of ordinary people, especially women, were not often recorded. This woman's voice, like so many others, has been lost. I do not even know if she were alive and willing to tell her story, whether she would tell it in English or in Irish.

In the above paragraphs, I have made a mistake I have often made in my life, of linking my Irish heritage with the clearly Irish name "O'Leary," and to the closest 
connection we had to Ireland in my grandfather who was born there. In fact all the branches of my family tree lead back to Ireland, though most of them have been growing in the U.S. for a longer time, and some had stops in Scotland, Germany, and England along the way. The woman who married my Grandpa O'Leary, Mary Ellen Laverty, came from a family of what likely would have been considered "lace curtain" Irish. They did not appreciate the relatively wild and often drunk new immigrants, according to my aunt. The Lavertys were among the first parishioners of Worcester's first Catholic parish. More than that, they were involved in pressuring the Bishop of New England (based in Boston at the time) to establish a church that became the first in the diocese of Worcester and Springfield, and they also donated land that became the first large Catholic cemetery in the city of Worcester. They had been in the United States since the 1820s, and were well established before the Irish poured into the country during the Famine years of the 1840s and 50s. If my Grandma O'Leary's family had a problem with her marrying the son of more recent immigrants, born in Ireland himself, I have not heard of it. Dennis was clearly a sober and hard-working young man, who must have impressed her family. My father says that by the time his father proposed to his future bride, he had already accumulated more money in his short time in the U.S. than the long-established Lavertys. They may or may not have heard the rumors that Dennis's father had smuggled guns and priests for Irelandanother great story the details of which are sadly mostly forgotten. Perhaps they would have approved, especially if the goal was to protect a Catholic Ireland. Either way, the only hesitancy regarding the marriage I have ever heard about was on my 
grandmother's part, and that purely based on her suitor's height. At about 5'7', she was taller than he was.

The Lavertys' story was recorded in Worcester history because the family was of some prominence in the local Church. They had enough wealth, land, and influence to be remembered. The stories about their contributions to the Worcester Diocese first came to me not through family lore, but through documents I stumbled upon in my research into the Irish in Worcester. In the local history section of the Worcester Public Library, I happened upon a well-written high school research paper on the history of the Irish in the city. There I came across mention of Laverty boys who were among the first catechists and choir members of Saint John's Church, the first Catholic Church in the city. I suspected right away that these Lavertys may be my relations, as my grandmother Mary Laverty O’Leary was a church organist, a regular worshipper, and a firm believer. She raised one nun, one seminarian who realized he was not cut out for the cloth when he fell in love with the woman he would marry, and several daily Mass goers. If there was anything clearly passed down through the LavertyO’Leary branch of my family, it was a strong Catholic faith. I was confirmed in my suspicion that these Lavertys were my relatives years later, when my cousin's genealogical work corroborated an article written on the history of Saint John's Church by historian Timothy Meagher (another Worcesterite), that I found online. Meagher, explaining the early history of the Church in Worcester, states, "As the number of Catholics in Worcester increased in the early 1830s so did the pressure to assign a permanent pastor to the town. In 1832 Robert Laverty wrote the bishop 
lamenting that new generations were being born, including his own children, who not only received little instruction in the faith, but were not even baptized. Though the bishop replied that he could do little to help the Worcester Catholics, Laverty persisted, writing again the next year." Later Father James Fitton, who soon would become founder of the College of the Holy Cross, finally succeeded in getting the church established in Worcester, with the Lavertys as one of its first and most active families.

According to his obituary in the Worcester Daily Spy of April 24, 1886, Robert's son and my great-great grandfather, John Laverty, was not only a popular ward politician in Worcester but also one of the founding members of Saint John's choir. These people had status enough to be recorded by name in the city's historical documents. I had not heard of them before starting my academic research, but my aunt the nun passed some of the story onto my cousin Mary Ann O'Leary Rodgers, who was tracing the family tree. I asked Mary Ann by e-mail if she had heard about the Lavertys' early involvement in Worcester's diocese. Her response illustrates once again the struggle with reconstructing family memory generations after those involved have passed on: "Yes, I had known the Lavertys were trying to get a priest here in Worcester. I think Sister Mary had told me that a while ago. They bought the land with the Carpenters (Zimmermans) that would have been Phillip [Laverty's] in-laws, then donated the property to build the first church in Worcester, Saint John's. [That] is the story I remember. I'm not sure if all of it is true. But the youngest got the middle name Fitton after Father Fitton the first priest." Mary Ann's comment, "I'm not sure if all of it is true," could be stated for every story I have shared here, and then 
multiplied by all of the other millions of descendants of the Irish in America. Even in this comparatively well-documented branch of my family tree, it is hard to know where facts end and imaginative reconstruction of stories takes over. Consider, then, how much more difficult it is to piece together the story of the masses of poor Irish who came to this country in the middle of the $19^{\text {th }}$-century. This is the case of the other half of my family.

My mother's maternal side of the family tree has more obscure, and more troubled roots. On her maternal side, I heard vague references as a child to their being from Cork and Mayo. Maybe they were from both places, and the immigrants met here in the States. They were Bests, Farleys, and McAuliffes. No one has yet traced that side all the way back, though some of my cousins are actively working on it. My cousin Dennis Bean has found on Ancestry.com that my maternal grandmother's family is actually from Limerick. I find it hard to believe that the Cork and Mayo rumors are totally unfounded. I had interest in our origins since childhood and while I wish I asked more questions, I know I asked where in Ireland we were from and those were always the counties named. While Dennis puts more faith in the documents he found online, I will not rule out entirely what I heard as a child, because I believe in oral history despite its limitations. Someone, somewhere must have told my grandmother we were from Cork and Mayo if that was what she passed down. Academically, I can understand the disconnect and the confusion. Here is another, wider gap in our story, which again mirrors the Irish-American story at large. Likely these were Famine immigrants. They settled in the mill towns along the Blackstone 
River, which runs from Providence, Rhode Island to Worcester. Their exact stories have been lost to time.

I have inherited the Bible of my great-great grandmother Mary Farley, her name embossed in gold on the thick leather cover. My mother was told that Mary bought that Bible piece by piece, eventually having it bound when she collected the whole thing. I can only imagine how much time, effort, and sweat went into paying for her treasure. She recorded her children's birth and marriage dates in the Bible, as many of her generation did. Someone later wrote in their death dates. Mary Farley's own death was never recorded in it, nor were her date and place of birth. I am the fifth woman to own the Bible, over five generations. Unfortunately, as with so much of this family story, the entries written into the Bible leave out much more than they tell us. Mary Farley did not write herself into the Bible, only her children, and only their dates of birth and marriage. There are no death dates, presumably because she herself did not live long enough to know them, and no one picked up on writing these Bible entries until possibly my grandmother nearly a century later. As a prosthetic for family memory this Bible is an imperfect one for what it leaves out, but also a perfect symbol for how I understand the gaps and fissures in the Irish-American story, as communal memory constructed despite or around what has been forgotten.

The most complete genealogical work in my family has been done on my mother's paternal side. Her cousin Irene Amsden traced their Ferris side of the family to counties Derry and Louth. Our two Irish ancestors from those counties likely met here in the U.S., with a common bond of Irish Catholicism trumping any county allegiances from home. Bridget McNally Ferris, my mother's paternal great- 
grandmother, left the Blackstone Valley in Massachusetts after marrying and raising a family here, and returned to her hometown of Termonfeckin in County Louth, where she subsequently drowned in a river. Family story says she had a photograph of her children commissioned sometime before she left. To our knowledge this photograph no longer exists, except in fading transgenerational memory. No one knows why she left, or why or how she drowned. This is where history fails us, in the loss of voices like hers, ordinary people behind the scenes.

This is where fiction can step in, to fill in the gaps, if not with historical fact then perhaps with emotional truth. In a novel I based loosely on Bridget's life, I tried to imagine what it must have felt like to be driven out of her home by poverty, to be forced to leave behind parents and siblings, and the only community she had ever known, knowing she would likely never see them again. I tried to imagine what it would be like travel to a new land, with foreign surroundings, and then as a woman to be home with children all day, while her husband likely made new social connections through work. I renamed my character Kate, not wanting to do a disservice to the real-life Bridget, whose real-life motivations I could never know for sure. For Kate, the upheaval of moving across the ocean results in a loneliness and depression she cannot bear. She is divided between the home country that cannot feed her, and the new country she does not love, and to which she does not feel connected. Yet that new country is the country of her children, and even her husband who is adjusting better to the move, settling in through his mill work. I wonder how close I came to the feelings of Bridget, at least one of whose sons became an alcoholic, as did his son (my grandfather) after him. One could argue for both nature and nurture as causes here-a 
genetic disposition toward depression and alcoholism, combined with the abandonment by and subsequent death of my great-grandfather's mother. These personal losses would of course have been heaped on top of the earlier traumas of experiencing famine and emigration, and even before these, thanks in part to British imperialism, the loss of the mother tongue. Transgenerational trauma theory would help to explain the alcoholism and depression we see later in the family history.

In my mother's family the loss, loneliness, and emotional damage can be traced down the generations. That emotional trauma does not just go away, buried with the originator in the grave. Bridget's son George, my mother's grandfather, was described to my mother (and then by her to me) as lazy, allowing his wife, reportedly a very good woman, to do everything while he lounged. His son, also named George, my mother's father, was an alcoholic with a gambling problem. He liked to bet on the horses, my mother would say, and he drank most of his pay before he got home. In true Angela's Ashes fashion, my mother's youngest sister was sent into bars to fetch him before he spent all his pay. On the nights they could not fetch him out of the bar, my grandmother might have added water to already thin soup, to make sure it stretched far enough to feed seven kids. This is not just a literary trope or an Irish stereotype; this was real life for my mother, her siblings, and their mother from the 1920s into the 1940s, by which time the young adult Ferris kids had voted their father out of the family, vowing to pitch in and help their mother with living expenses if she would ask him to leave. My mother's brother, also named George, detested his father for his drinking and what it did to the family, especially to his mother. He also detested being named after his father. This third George was nothing like the other 
two who came before him. A loving son, brother, husband, and father, George Arand Ferris, my uncle, put himself through Boston University's School of Journalism with the help of the GI Bill. He had a career as a journalist and a technical writer. There was nothing lazy about him. He was happy that there was one difference between his name and his father's name, for according to my mother, their father had no middle name. My Uncle George was the only George A. Ferris. His middle name Arand had been their Grandmother Grace Ferris's maiden name. She is the one who both put up with the original lazy George, and warned my grandmother about marrying her son George. She told my grandmother she would have a hard life if she married her boy. She was right. My grandmother always liked her, according to my mother, which might explain why she gave her George the middle name Arand (and my mother the middle name Grace). When my Uncle Bob, in an act of kindness, belatedly put a tombstone on his father's previously unmarked grave, he mistakenly added the middle initial " $\mathrm{A}$ " to his name. My Uncle George was incensed that the one difference he held dear between his own name and his father's was thereby erased. The bitterness of past trauma lasted at least into my mother's generation, with her hatred of alcohol, and her brother George's hatred of his own name, which he inherited from his father and grandfather before him. In my own generation alcoholism and depression still persist among some members. The origins of the trauma are largely forgotten by most members of the family, but the after effects still linger.

You might say none of this has anything to do with Ireland, or you might say that of course, the Irish are known for being alcoholics. I say it is connected to Ireland, but not with the familiar stereotypes of drunkenness, and perhaps not even 
with the more sensitive analyses of alcoholism brought on by a combination of genetics and depression. I see a larger, social-historical context behind the many different types of connections to Ireland and America found even in my own family tree. If my theory about my maternal great-great grandmother Bridget McNally Ferris is correct, it is the loss of her family and community in Ireland that was at the heart of her struggles. Long before I studied postcolonial theory, I named the novel I wrote about her Divided, to express how she felt being separated from her homeland, caught between her old and new countries. It was likely a similar loss to that experienced by my paternal great-grandmother, Sarah Moriarty O'Leary, who is remembered as silent and cross. How far does this loss get carried? How does it get woven into the fabric of what become American lives? As different as the experiences of immigration were in the different branches of my family, both sides are marked by the connection to an Irish homeland. And yet, both sides are also marked by forgetting most of what that connection entailed.

Sadly, the originators and the keepers of these stories have been silenced, either through death, through dementia, or more recently (as I have written and revised this dissertation) through debilitating strokes suffered by both my aunt, Sister Mary O'Leary, and my mother, Rita Grace Ferris O'Leary. Sister Mary's stroke did not take away her speech, though it did set it back briefly. She was able to regain speech, and still holds onto the family memories, but her perception of the present is altered. She is probably better equipped to tell you a family story from 60 years ago than to tell you who came to visit her today. That after being sharp as a tack, driving and volunteering at the hospital from which she had only recently retired, at 90 years old. My mother 
also suffered her stroke at 90, about four months after her sister-in-law did. In my mother's case the stroke left her with aphasia, the inability to recall words she wants to use. It is hard to watch her struggle to come up with what she wants to say. She can sometimes manage a few words, but there is so much more in her she cannot get out. She can speak, physically that is; she can read a song off a page or recite a memorized prayer. Reading does not require the kind of recall spontaneous speech does, and the prayers and songs are so ingrained in her she does not have to think about them to recite them at Mass. The aphasia, though, has made it impossible for her to share a family story with me again. Sometimes she can get out a word or two, in a style her speech therapist calls "telegraphing." It is up to the listener to fill in the gaps and make connections to complete the sentence. Instead of life imitating art, I find in this situation that life is imitating history. In my mother's case we have to guess the missing words until she tells us we are correct. Thankfully she is still here to do that much. More distant ancestors are not, so their voices remain completely silenced with some remnants, such as a family Bible or obituary, standing in for the speech we cannot hear. We use imagination to fill in the rest of the story.

My family history is marked at least as much by what I do not know as by what I know, and I probably know more than most, due to the combination of the curiosity I have had about my heritage since I was a child, and my academic pursuits. I am finding at wakes and funerals, which is where we run into each other these days as our parents' generation dies out, that my cousins have also been left with stories. Sometimes we have different versions of the same stories, sometimes different stories altogether. We all have scraps and pieces, depending on the perspectives of our 
parents, and their relative willingness to share, combined with our own past willingness to listen, to take these stories in as children and young adults. In this we reflect the larger Irish-American community that lost its access to memory of the early decades of mass immigration to this country. As the years went on these memories died out along with those who lived them and their immediate descendants. The stories may not have been told by new immigrants busy surviving in a new place. They may have been withheld based on shame over poverty. They may have been distorted through the generations if they were retold at all. They may not have been listened to by their children and grandchildren, new Americans trying to make their way up the social ladder. For a combination of all of these reasons, snatches and fragments now remain at best, over 100 years later, with stereotypes and imagination filling in the gaps. We suffer from a collective aphasia, an inability to recall, a loss for words to tell the stories of how our families went from being Irish to being American, and what they had to give up along the way.

Yet so many of us still want to identify as Irish, to find a connection with this place about which we know so little. It is this connection to Ireland that brings me to this project. Why did I always look at Ireland as home, even though I had never been there, and my parents had never been there or shown interest in going? When they did not even play Irish music in the house, unless you count Bing Crosby? Why, among eight siblings, are only two of us interested in our Irish heritage in any depth? And why, as the youngest, was I the first to have this interest by a couple of decades? What was left for my parents to hand down to me was an Irish name, fair skin that burned too easily in the sun and freckles, and a Catholic faith. As a child I had no idea 
of the connection between these remnants of our Irish history. I did not know how hard my ancestors had fought to keep a faith that I would come to resent as a teenager, forced into mandatory weekly Mass attendance, and - the horror-even week day Holy Day Masses a few times a year. Perhaps if I had made the connection between the Irish heritage I looked on with such pride and the faith I had a hard time swallowing, I would have taken more kindly to being seemingly the only person under 60 in Mass on a Holy Day.

In this project, my investigation into how an Irish-American narrative was written of these disparate circumstances continues. I examine Irish-American fiction and memoir from just after World War II through the early 2000s. These books show the evolution of an Irish-American ethnic identity as the generations go on, in an ongoing process of selective remembering and forgetting, with silences being replaced by symbols. To complete the study, I also look at $21^{\text {st }}$ century fiction from Ireland that takes as its subject emigration to the United States, and the endless transatlantic cultural exchange. Both Ireland and America, and the Irish people who moved between them as well as their descendants, would forever be marked by the crossing. In all of the works I have chosen, whether they are fiction or memoir, I see the authors piecing together the fragments of their own Irish and Irish-American experience, their own family histories and communal histories. They are filling in the gaps in memory with their imaginations, and in doing so they both capture and add to how the IrishAmerican story has been lived and told. 


\section{TABLE OF CONTENTS}

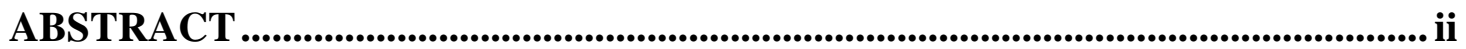

ACKNOWLEDGMENTS ................................................................................................... iv

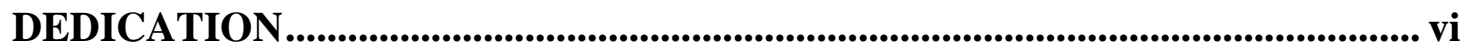

PREFACE: The Personal Becomes Academic: Grampa O'Leary's O and the Loss of

Connection to Ireland ...................................................................................... vii

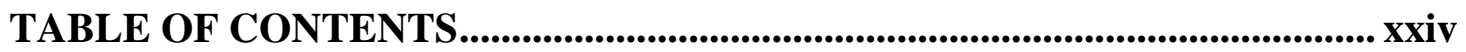

INTRODUCTION....................................................................................................................... 1

CHAPTER 1: Irish Skin, Yankee Masks: Post-World War II Novels and the

Assimilation of the Irish-American Community..................................................45

CHAPTER 2: "Not One Thing Nor the Other": In-Between Characters in the Fiction

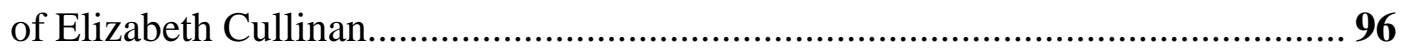

CHAPTER 3: The Exception to the Rule: Michael Patrick MacDonald's Memoirs of

South Boston and Dissonance in the Irish-American Narrative 137

CHAPTER 4: Ireland Writes Back: Roddy Doyle, John Ford, and the Construction of the Irish-American Narrative 180

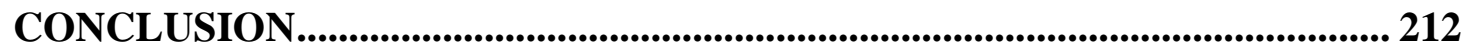

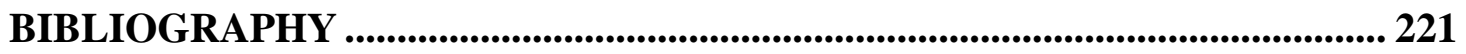




\section{INTRODUCTION}

History stays with us, even when we don't want it to. Forgotten or unwritten, history shifts beneath our feet, one minute imperceptibly, the next tectonically, shaping nations, neighborhoods, and families.

-- Peter Quinn, Looking for Jimmy

The Irish-American ${ }^{1}$ narrative is a story told by a diasporic people longing to maintain a connection with a homeland that is receding into their past. It is also a narrative of ethnic identity formation in America, and the changes that needed to be made in order to fit in. This narrative is not only written by novelists, memoirists, poets, playwrights, songwriters, and filmmakers - all of whom have done their partbut also by the everyday people who told their stories, and by those who withheld their stories but let them come through in their actions and attitudes toward their new country and their old one. It is a narrative told about a partly remembered and partly imagined homeland through a filter of distance and time, from across an ocean and across generations. It is a story told to protect the Irish-American self from memories of past trauma — the dual pains of colonialism and emigration, the shame of poverty and hunger. The narrative paints a picture of a people who have thrived in America despite facing oppression on both sides of the Atlantic. In creating this narrative, the Irish in America have borrowed both from the nationalist rhetoric of Irish independence, and from the rhetoric of the American dream. This narrative of a people in diaspora has preserved for the Irish in America a sense of their own ethnic uniqueness when faced with the anxiety of losing themselves in a dull, if profitable,

\footnotetext{
${ }^{1}$ Throughout this study, the term "Irish-American" will only be hyphenated when being used as a compound modifier for a noun that follows it. Thus I will speak of "the Irish-American narrative" or "Irish-American literature," but will not hyphenate when referring to Irish Americans as a people, or an individual Irish American.
} 
American whiteness. What subsequent generations would remember-and what they would work to forget — of Ireland and their ancestors' early years in America, would become the core of the Irish-American narrative.

In the Irish-American literature in this study there exists a tension between the drive to become respectable Americans and the fear of losing themselves as they begin to blend in. This prompts a call to ethnic uniqueness in the Irish-American narrative, an effort to cling to some sense of Irishness. There is tension in the narrative as IrishAmericans fight against becoming the dreaded "Yank." Yet that is what they needed to become to live the American dream. In examining this thing called "the IrishAmerican narrative," it must be said that there is no one Irish-American experience. J.J. Lee makes this clear in the introduction to Making the Irish American. Lee reminds us that in thinking about who an Irish American is, regional differences and particular circumstances of each city where the Irish settled need to be considered (1113). As historian Timothy Meagher argues in Inventing Irish America, even in cities as close together as Boston and Worcester, Massachusetts, the experience of the Irish varied greatly because of the political and social climate, and the ethnic makeup, that greeted them when they arrived (15). Clearly then the experience of the Irish in the American Midwest or South would vary from that of the Northeast cities even more dramatically, and within those regions there would be more differences still, depending on the immigrants' social class, gender, profession or lack thereof, educational background, and language spoken upon entry, not to mention the time period in which the immigrants arrived. In her work on the sizable Irish-American Protestant population, Mary C. Kelly also adds religious difference into the mix of 
what is traditionally thought of as a Catholic story (The Shamrock and the Lily). The Irish-American narrative, then, is not necessarily the true experience for every Irish immigrant and person of Irish descent living in the U.S. The Irish-American narrative being discussed here is instead a generalization. It is a story popularized and told enough times that it has become the known version of the experience of the Irish in the United States. It largely leaves out those who remained poor, those who are Protestant, and those outside of the cities of the Northeast and Chicago, cities so well known for their Irish presence. It also leaves out Irish involvement in early twentieth century radical politics, a strain of Irishness that would need to be erased in favor of middle class respectability. In this sense, the Irish-American narrative is akin to other narratives of nation, which in part use fiction and myth to create a story that binds a people, an "imagined community," together. The narrative glosses over differences between those people, leaving out some of their experiences altogether. Those left out experiences become gaps in the larger story.

Though there may not be one Irish-American experience, there is a popular version of the narrative of Irish-American experience that is most familiar to the American public, most notably to those who identify as Irish American. It is largely the story of poverty-stricken, if not starving, Irish Catholics, forced from their beloved homeland by unsympathetic landlords and English colonial policies that kept them poor. The story continues with more harsh treatment by the largely Anglo-Protestant establishment upon arrival in the United States, famously symbolized by "No Irish Need Apply" signs. The Irish immigrants in America persisted despite prejudice they faced, climbing up the American socio-economic ladder through pluck, hard work, 
and political savvy. They sent money back home to bring over siblings and cousins, so they, too, could climb out of poverty. At the same time the immigrants and their descendants looked back to Ireland and tried to maintain a sense of ethnic difference by hanging on to stories, music, and nostalgia for an island many of them had never seen. As the culminating chapter of this project will show, a wish-fulfillment ending to the narrative that has yet to end is embodied in John Ford's classic film, The Quiet Man, when the returned Yank reclaims his ancestral home. The wish is to both have American financial success and to still be recognizably Irish.

Over the years that wish has led to distortions in what being Irish means. What could it mean to a third generation Irish American or beyond? With time and space separating them from an ancestral homeland, sometimes what substitutes for an Irish identity are old stereotypes that have lost their sting with the worst discrimination far in the past. These stereotypes have sometimes been internalized by those who do not understand the history of their use. When this process is taken to the extreme, young Irish Americans celebrate the drunken Irish stereotype with t-shirts, bumper stickers and a proud attitude claiming drunkenness as part of their heritage. Some of the stereotypes are more benign. Images that are played and replayed in popular films and television, shown in the Aran-knit sweater-clad singers on covers of albums and CDs, celebrated with seas of green at Saint Patrick's Day parades, and in The Quiet Man itself - these become Irish-American identity as the years roll on between when the mass of Irish immigrants arrived in this country and the present time. Studying IrishAmerican literature written since World War II sheds light on how Irish-American identity, preserved in this narrative, has come to its current state. The trauma of 
colonialism and the Great Famine, compounded by mass emigration during the Famine and for several decades beyond, left the Irish in diaspora severed from natural systems of cultural inheritance. The Irish-American narrative clings to the fragments of what is remembered of Irishness, while filling in the gaps of what is forgotten in imaginative ways.

This project traces Irish ethnic identity formation in the United States and the creation of the Irish-American narrative throughout the twentieth century as reflected in Irish-American life-writing — autobiographical or at least semi-autobiographical fiction and memoir - from just after World War II to the early 2000s. With careful consideration of author biases about their own communities and the imaginative reconstruction involved in both fiction and memoir, these life-writing genres "are immensely valuable for insights into an immigrant's life and his family and community from the moment of entry into the United States" (Weinberg 409). All of the works included in this study examine in some way the question of what it means to be Irish in America. The authors in this study collectively show how an Irish identity was given up in America and eventually pieced back together again. Some of the original elements remained, but others were forgotten, misunderstood, or invented. The Irish-American narrative tells of a rise from poverty and oppression to American comfort and respectability. There is pride in this rise, but there is also loss. This study argues that symbol has replaced substance in popular representations of the Irish in America, and that imagination has been used to create an Irish-American identity that attempts to soothe the pain of what has been lost. 
The theoretical tools that will be used to examine these works will center on notions of home and nation, applying those concepts to a people in diaspora and how they see themselves in relation to two different homes, the one they left behind but that still informs their identity, and the one in which they live and raise their families. In the early twentieth century, the way Irish Americans see themselves against a dominant Anglo-Protestant culture can be traced back to the colonial setting they have left. For this reason some tenets of postcolonial theory will be applied to this American literature of a displaced Irish population. This move from one homeland to another, especially when forced by poverty rather than a desire to leave, does not come without trauma. As such, theories of individual trauma and trauma as it is passed down the generations will also be employed. The theory of ethnic identity formation as an ongoing process is also useful to understand how the Irish understand themselves in America. Finally, what makes it into a national or diasporic narrative has at least as much to do with what is forgotten as what is remembered in the name of presenting a unified whole. Theories of cultural memory and forgetting will be used to understand the fractured nature of the Irish-American story that is passed on, and the gaps and fissures found therein.

\section{Home is what we imagine it to be.}

Before trying to gain a better understanding of the Irish-American narrative, one must know the how national narratives are constructed. Benedict Anderson, who famously theorized nation as an "imagined community," explains how the idea of "nation" is only about two centuries old, yet national narratives claim for themselves 
ancient origins. Anderson compares the narration of nation with telling an adolescent of his early childhood through photographs and stories: "Because [early childhood] cannot be 'remembered,' [it] must be narrated" (204). In this way a national narrative reaches back through time, connecting generations, explaining an origin that the current generation cannot remember. Language allows national narratives to reach back through time. National narratives also reach across space, bringing together large numbers of people who will never come into contact with one another: "the members of even the smallest nation will never know most of their fellow-members, meet them, or even hear of them, yet in the minds of each lives the image of their community" (6). As Anderson explains, it takes a leap of the imagination to make these connections across time and space. The national narrative allows people of a nation to make that imaginative leap. An even larger leap will be needed to carry that imagined community into diasporic spaces.

Anderson quotes Ernest Gellner on how nations are formed: "Nationalism is not the awakening of nations to self-consciousness: it invents nations where they do not exist"' (6). Gellner further explains how nations are imagined in Nations and Nationalism, in general using negative terms to explain how multiple cultures are combined and sometimes effaced to create one dominant narrative for the nation state: ...nationalism is not the awakening of an old, latent, dormant force, though that is how it does indeed present itself. It is in reality the consequence of a new form of social organization, based on deeply internalized, educationdependent high cultures, each protected by its own state. It uses some of the pre-existent cultures, generally transforming them in the process, but it cannot possibly use them all. There are too many of them. (48)

Essentially, then, what results is a form of e pluribus unum: out of many, one, but in a different way than the American motto of popular voice intends it. Gellner is saying 
that out of many cultures in a place before the nationalist movement, one main narrative is formed. That narrative cannot represent all of the cultures that existed prior in a particular geographic area, at least not fully. The rest are forgotten, elided. The official narrative is of those who are in charge at the time, the educated ruling class. It is the narrative that they want to put forth for their nation. The "one" in this case does not necessarily fully represent the "many," even if that is what the national rhetoric says. Yet it is meant to be a binding principle. What results is a national rhetoric without full participation, with minor and unsanctioned cultures, what David Lloyd calls "recalcitrant elements," being written out and written over. Though not sanctioned by any official state, a narrative of a people in diaspora is imagined in much the same way. Some elements make it into the story that is passed on, and some are left out. In the United States, the "wild Irish" who did not step in line to middle class values espoused by a narrative of forward progress were among those left out of the story. The narrative celebrates the Henry Fords and the JFKs, who showed how far we had risen from humble beginnings, but not, for example, the Irish who were still in the projects of South Boston near the end of the $20^{\text {th }}$ century.

Ernest Renan's definition of nation as a "spiritual principle" (19) is helpful for understanding how the idea of nation was able to be packed up and moved with the Irish and other emigrants who left their homelands. A spiritual principle is not restricted to a certain geography. It is portable, but the way it travels must be considered here. For Renan, "the social capital on which one bases a national idea" is "to have common glories in the past and to have a common will in the present; to have performed great deeds together, to wish to perform still more." He says, "these are the 
essential conditions for being a people" (19). Emigrants meet the first part of the definition, but they would struggle to meet the second. Nineteenth and early twentieth century emigrants, especially, would likely not see their homelands again because of difficulty of travel. Even if they desired to continue a common life with their country people at home, their physical circumstances would prevent them from doing so. That did not stop many Irish in America from following the news from home, and from cheering on (and sometimes financially supporting) their nationalist brothers and sisters as they fought for independence from Britain. A nation, according to Homi Bhabha's rewriting of Anderson, is written into being, and is always in the process of being written. For the Irish in America, "home" is Ireland, but while the Irish national story is always in the process of being rewritten, home in the emigrant mind stays what it was upon leaving. The concept of home passed onto future generations in the new country is static, if tinged with nostalgia, while back in the homeland things are always changing. Even if emigrants carry the spiritual principle of the nation with them, they cannot fully participate in the future of that nation. They are left with a haunting vision of the past instead. To continue to include themselves in the Irish national narrative, Irish Americans have to forget that they have left, that they have a disconnect from the mother country, and that that mother country has moved on without them. Yet the very reason they can write their Irish-American success story is because they are Americans. They have to re-member their experience in such a way that they can have it both ways, still hanging onto what they know of Irishness, while celebrating American success. 
This kind of investment, both emotionally and financially, in the homeland, is part of historian Kevin Kenny's qualifications for what can be considered diaspora. He explains that the term diaspora should not be applied to all migrants, but selectively, to those who have been forced to move because of a major event, such as genocide, slavery, or famine. Diasporic peoples, he says, continue to involve themselves in affairs of the homeland, or in the idea of a homeland. They anticipate returning to the homeland some day. Also, they migrate to multiple locations, and they communicate between these locations as members of a diaspora (13-14). Kenny argues that only the Great Famine-era Irish fit these requirements, not Irish who left at other times or for other reasons (32). He also makes clear that when the Irish had the opportunity to return to a free Ireland, after Independence, very few did (61). Yet the Irish and their descendants in America helped fund the war for independence. Even Kenny admits that "New York City became the leading center of Irish republican activism in the world" (53). Into the first decades of the $20^{\text {th }}$ century, then, the Irish in America were still very much interested in their homeland, even if they had become too comfortable as Americans to return. It is indeed a complicated relationship, as will be shown in the literature involved in this study. Even three generations into this country, Irish-American authors still strongly identify with Ireland as at least a spiritual "home." The spiritual element is so prominent that for many contemporary memoirists, the journey "back" to Ireland, even if they had never been there, is put in the language of a pilgrimage (Rogers Irish-American Autobiography 147). To Kenny's caution about oversimplifying or overusing the term diaspora, one could say 
that what matters to the Irish-American narrative is the perception, if not the reality, of belonging to Ireland, this perception of Ireland as home.

As technology for faster travel and communication has improved, the Irish in America have been able to rebuild a relationship with that home. The Atlantic crossing that used to take several weeks now takes several hours. Now with the Internet, the exchange of cultures can be instant, and it can go both ways. The diaspora has now gone digital. The opportunities and disadvantages of social media must even be beyond what Arjun Appadurai imagined in 1996, when he theorized that electronic media would bring us beyond nation, to transnational diasporic spheres (4). His vision has come true and then some, as the Internet breaks down walls between countries. Now more than ever, the idea of home can travel. Appadurai sees this portability of culture as "fundamentally fractal" (46) and leading to chaos (47). He says, "It is in this atmosphere that the invention of tradition (and of ethnicity, kinship, and other identity markers) can become slippery, as the search for certainties is regularly frustrated by the fluidities of transnational communication" (44). Appadurai's view is not all negative, however, as this slipperiness can lead to opportunity for new social relationships beyond those tied to nation or nation-state. Culturalism, according to Appadurai, is the willful connection of a group to a culture. Groups in diaspora can choose their own ethnic or national affinities. While it may be anxiety-provoking for the immigrant to no longer be physically connected to a homeland, thus severing traditional modes of cultural transmission, Appadurai's "ethnoscapes" allow for new means of connectivity in a transnational space. 
Charles Fanning sees creative potential in being of more than one country. He calls the Irish-American way of being "ethnicity as liberating doubleness," which he says is "a view of ethnic otherness not as destructive self-estrangement but as creative expansion of possibility" (371). It must be noted here that this possibility of "liberating doubleness" is attributable at least in part to the fair skin of the Irish. As Appadurai points out, other former colonial subjects with darker complexions do not always have as much choice in how they will remake themselves in this country (171). That the nineteenth-century Irish were at first also not welcomed into white America is a key part of the Irish-American narrative. That they were able to eventually blend in is something the narrative would rather forget in its claim for ethnic difference. Put in Appadurai's terms, those who actively identify as Irish in America would like to exist in that ethnoscape that transcends national boundaries, to claim for themselves both an Irish and an American home. While Fanning correctly sees the creative possibility in that arrangement, claiming an Irish home comes with a history of trauma that has only been superficially remembered in the Irish-American narrative.

\section{Trauma from home weighs down the emigrant's baggage.}

The spiritual principle of the nation is not the only thing emigrants carry with them as they head out into what becomes diaspora. The traumas of home tend to come along as well. One defining traumatic event carried with mid-nineteenth-century emigrants from Ireland was the Great Famine of 1845-1852. With the haunting memory of the Famine, the Irish carried a bitter distaste for the English, who ruled Ireland at the time, and whom they blamed for both the devastation at home and their 
need to leave. Perhaps no one expresses the importance of the Famine to IrishAmerican identity better than Peter Quinn, who claims, "For Irish Catholics in America, the Famine was the forge of their identity, fire and anvil, the scattering time of flight and dissolution, and the moment of regathering that would one day make them an influential part of the world's most powerful democracy" (229). Yet Quinn also emphasizes the silence around the Famine, saying, "The formative impact of the Famine... was paid little more than lip service, usually in the form of ritualized indictments of British treachery" (13). As J.J. Lee says, "the memory of the Famine became the focal point around which crystalized Irish Americans' search for historical understanding of why they found themselves where they were" (22). John Mitchel, an Irish nationalist exiled in New York, famously said, "The almighty, indeed, sent the potato blight, but the English created the famine" (qtd. in Quinn 225, and in Kenny 31). It may have been best expressed by Mitchel, but this attitude was pervasive in the Irish-American community, and it captured their sense of having been grievously wronged. Remembered or pushed deep into the subconscious, discussed or kept quiet, the Famine's impact on mid-nineteenth-century Irish immigrants and their subsequent generations cannot be denied.

The harsh feelings the Irish had toward the English came from the belief that they had been left to die in the Famine. English laissezfaire economics let the Famine run its course, with very little aid to the suffering. When there was aid it came in the form of work schemes that did little to help men who were starving. This treatment during the Famine was a final insult after hundreds of years of repressive laws meant to restrict Irish Catholics from practicing their faith and speaking their language in 
their own country. In Black Skin, White Masks, Frantz Fanon explains the damage of colonialism:

Every colonized people - in other words, every people in whose soul an inferiority complex has been created by the death and burial of its local cultural originality - finds itself face to face with the language of the civilizing nation; that is, with the culture of the mother country. The colonized is elevated above his jungle status in proportion to his adoption of the mother country's cultural standards. (18)

While it may not have been the jungle in the Irish case (the word "bog" would be a fair substitute), the process was similar, as was the psychological damage sustained. Fanon terms this psychological damage a "psychoexistential complex" (Black Skin 12), and in his later book, The Wretched of the Earth, explains the resultant identity crisis, which causes the colonized subject to ask, "Who am I in reality?" (182). The process of colonization feeds the colonized person myths about who he or she is: how savage, how uncivilized, and therefore how in need of being governed by someone else. After being used so effectively in Ireland, this process was then replicated in empires all over the world. The process of planting that inferiority complex was so thorough that though Irish nationalists resented the English and knew they should be independent from them, they still measured their success by them. As David Lloyd and Declan Kiberd argue, they even modeled their newly independent Ireland after England in terms of its political, economic, and educational systems. The names may have changed from colonial days, having been "spray-painted green," as Kiberd says, but the systems largely remained the same (Kiberd 551-561; Lloyd Anomolous 54). This psychoexistential complex left the Irish questioning their own value not only at home, but also in America where they faced at first similar discrimination from another Anglo-Protestant ascendancy. In both places their faith, their language, and 
their way of life were devalued, and whether the Irish were aware of it happening or not, they took that devaluation to heart.

Appealing to Fanon to explain the inferiority complex experienced by the Irish in Ireland and the United States is not meant to dismiss the very real difference of skin color between the dark-skinned former colonial subjects of whom Fanon writes, and the fair-skinned Irish who could much more easily blend into the Anglo world. David Roediger and Noel Ignatiev have famously explained the process by which the Irish "became white" in the United States. Roediger cites W.E.B. Dubois' concept of the "wages of whiteness" by which he meant that the white working class could claim social and psychological benefits even if their pay was not higher than some freed African Americans. These benefits came precisely from being able to say that they were "not slaves" and "not blacks". According to Dubois, this allowed white workers to be satisfied with lower wages and exploited by the capitalist system (Roediger 13). Roediger argues that under different circumstances the Irish may have resisted being so conflated with the Anglo majority, "But within the constrained choices and high risks of antebellum American politics such a choice [to take on a white identity] was quite logical" (144). Similarly, Noel Ignatiev explains that the nineteenth century Irish arriving in America "came to a society in which color was important in determining social position. It was not a pattern they were familiar with and they bore no responsibility for it; nevertheless, they adapted to it in short order." He continues, "To enter the white race was a strategy to secure an advantage in a competitive society" (2). The nineteenth century Irish in America moved into a racial minefield they had not experienced at home. 
Kevin Kenny disputes some of the claims of these whiteness studies, saying, “to argue, as some historians do, that the Irish 'opted for' or 'chose' whiteness, deliberately distancing themselves from African Americans in order to advance themselves socially, seems unnecessarily abstract and tends also to overestimate the degree of conscious agency involved in the process" (American Irish 67). Elsewhere Kenny argues for a need for historians to understand the way the Irish felt about themselves racially, rather than just going by sources found in political magazines most Irish immigrants likely did not read ("Race, Violence” 375). Kenny agrees with Ignatiev that "the American Irish did not create the social and racial hierarchy into which they came," but continues with a line of reasoning Ignatiev does not: "to expect them to have overturned this hierarchy in the course of putting food on their tables is surely unrealistic" (American Irish 68). Kenny does not deny the considerable IrishAmerican racism in the nineteenth century, but asks "for a better historical explanation of that racism — one that shifts at least part of the focus away from individual agency and toward the wider social and cultural structures in which both Irish immigrants and African Americans operated" (American Irish 68). Peter Quinn, too, critiques Ignatiev (he does not mention David Roediger). Quinn says Ignatiev's “version of history ignores the particularity of the Irish experience" (276). He criticizes Ignatiev for "barely" mentioning the Great Famine that brought so many Irish to America, ignoring that, "For the Irish, the bulk of whom had arrived as a result of the Great Famine ...the Republican theory of free labor could only have reeked of the free-market orthodoxies that had allowed the British government to abandon relief efforts while the Irish starved" (276). Ignatiev's book advances a simplified answer to a complex question, 
and both Kenny and Quinn call for more sensitive analysis of nineteenth century race relations.

Still, no matter how the story of race in the nineteenth century United States is told, by the mid-twentieth century when the first books in this study are written, the Irish are no longer facing discrimination for their religion, and have managed quite successfully to blend into white America. Clearly African Americans and other peoples of color have been denied that privilege. Ongoing racism for African Americans especially is an everyday reminder that the Irish case was different. This does not erase the damage that was done to Irish language and culture, or the inferiority complex experienced by Irish looking to emulate English systems of government and education at home, and "Yankee" attitudes toward wealth and respectability as the way up the American socioeconomic ladder when they left. Quinn says of the Irish in America, they "struggled to adopt a new identity while holding fast to the old" (276). There was anxiety in this process over what of the old identity was being lost as they found economic success in their new country.

Mass emigration was itself another trauma. Emigrants had to leave behind all they had known, without much choice. Between 1841 and 1851 the Irish population of about 8 million was reduced by about 2.5 million. Those who emigrated (1.5 million) exceeded those who died from starvation and disease (1 million) (Deane 72). Emigration during and after the Famine years added a permanent sense of loss to both the Irish and the Irish-American narratives. On the Irish side of the Atlantic, the loss was of family members and neighbors, whom until relatively recent years were likely not to be seen again after crossing the ocean. On the American side, the loss was of 
the native Irish home and the identity that went along with that. Eamonn Wall stresses the connection between Irish people and a sense of place, arguing, "In Ireland, place, personality, and identity are inseparable" (204). Upon leaving that place where one's family has resided for generations - perhaps centuries - one would have to suffer an upheaval in personal identity. In America new immigrants would have to be disoriented without that connection to place that had defined themselves and their families.

For those who left Ireland during the Famine years, the Famine was the traumatic event they would forever be working through. Leaving Ireland would compound that trauma, as it may have been felt as an act of abandonment of their suffering community. In her work on trauma theory, Cathy Caruth claims that trauma is not from dying, but from surviving, or escaping death (58). Borrowing from Freud, Caruth explains the traumatic event cannot be processed right away, but must be worked out through repetition. Caruth's work explains why the Famine would become a defining piece of the Irish-American narrative. She says, "Repetition... is not simply the attempt to grasp that one has almost died but, more fundamentally and enigmatically, the very attempt to claim one's own survival. If history is to be understood as the history of a trauma, it is a history that is experienced as the endless attempt to assume one's survival as one's own" (64). The Irish-American narrative, seen in this light, is one of survival. It is the story not only of surviving, but of eventually thriving on American soil. The true pain of the Famine and leaving home could not be grappled with right away, especially as those who fled Ireland worked to 
establish themselves in America under trying circumstances of poverty and discrimination.

Recent work in Holocaust studies argues that trauma is not confined to the generation that experiences it. Marianne Hirsch calls the phenomenon experienced by children of Holocaust survivors "postmemory," whereby the second generation has such vivid associations with their parents' homelands, and ghetto and camp experiences, that it is almost as if they remember them themselves. Hirsch posits that "children of those directly affected by collective trauma inherit a horrific, unknown, and unknowable past that their parents were not meant to survive.... Loss of family, of home, of a feeling of belonging and safety in the world 'bleed' from one generation to the next" ("The Generation of Postmemory" 112). This bleeding of the effects of trauma happens not just based on what the parents say about the event, but in what they withhold, and in how they interact with their children and the world. The children observe it all. As Hirsch was developing her theory, the third post-Holocaust generation was just coming to maturity, so there has not been the time to look longitudinally at how far these traumatic memories are passed down compared to generations since the Great Famine in Ireland. There also is not the photographic evidence of the Famine era as there is of the lives of European Jews before and during the war, photos that Hirsch finds so important to the way memory of the event is structured. If the Irish in America after the Famine did not have photos, they had stories, and where they did not have stories they had meaningful silences. It is not an exact analogy to compare post-Famine memory with post-Holocaust memory then, but Hirsch's theory is a helpful way to think through how traumatic memory is passed on. 
Michael Rothberg's theory of multidirectional memory allows for connections to be made across mass atrocities and traumatic events such as the Holocaust, slavery, and colonialism. The Great Irish Famine, if it were in more recent historical memory, would likely have made Rothberg's list, too. Its survivors meet the criteria Hirsch describes when she says, "For survivors who have been separated and exiled from a ravaged world, memory is necessarily an act not only of recall, but also of mourning often inflected by anger, rage, and despair" ("Past Lives" 661). Hirsch goes on to talk about the survivors' children, saying the home of their identity is a place they have never seen and to which they cannot return. Even if they do go back, the place is irrevocably changed, so they cannot go back; it is not the same (661). Though there are obvious differences between intentional genocide and letting a potato blight and laissez faire economics clear the land, the home of the mid-nineteenth century Irish was ravaged beyond what future generations would recognize, and those feelings of mourning, anger, rage, and despair must have inflected the way they raised their children in America. Commenting on Hirsch's idea of postmemory, Gabriele Schwab explains how trauma is passed on, saying, "Children of a traumatized parental generation... become avid readers of silences and memory traces hidden in a face that is frozen in grief, a forced smile that does not feel quite right, an apparently unmotivated flare-up of rage, or chronic depression....Children read their parents' unconscious more generally in the embodied language of affects" (14). Anxieties over being respectable Americans were among the "haunting legacies," to borrow Schwab's term, of the Great Famine. The trauma would come across, eventually, into the second generation who raised the third, as a desire to be clean and respectable, a 
desire not to ever look or act poor. Sometimes it would come across as a desire to distance oneself from Irishness, at least the brand of which associated with being uncivilized and wild. If it does not make common lists of more recent atrocities, the Famine's legacy is still never very far from Irish-American writing. The story of Irish America has its origins in the Famine even when those origins are silenced.

It would take subsequent generations - grandchildren or even greatgrandchildren of Famine survivors, to do the post-traumatic work caused by the Famine. That work would involve unburying what had been forgotten because it was too painful an experience at the time it happened. It is work that is still being done over 150 years later. In works of Irish and Irish-American fiction written into the $21^{\text {st }}$ century, the Famine and its ghosts still appear on a regular basis. If these ghosts are not always called Famine ghosts specifically, they are illustrated in a transgenerational fear of, and shame over, poverty and hunger. Homi Bhabha advises that "the critic must attempt to fully realize, and take responsibility for, the unspoken, unrepresented pasts that haunt the historical present" (Location 18). It becomes clear in reading contemporary Irish and Irish-American literature how alive those ghosts are. Mary C. Kelly traces the process of unburying those ghosts, noting with Peter Quinn, J.J. Lee, and others how the Famine was the defining event for the forging of Irish identity in America. She shows how it takes 150 years for public Famine memorials to emerge, and exposes the reasons for that delay. In the late nineteenth century, when the memory of the Famine should have still been fresh in Irish-American minds, Kelly explains "larger religious, civic, and political ethnic collectives avoided public illumination of shadows that were still too appalling and incomprehensible-literally 
unspeakable—-to confront" (Ireland's Great Famine 86). The Famine and subsequent emigration was the trauma that Irish-Americans could not forget, but also one they could not bear to remember. Its absence from the early Irish-American narrative created a gap filled in largely by unbridled contempt for the English, and the drive to cover poverty with American success. Still, the ghosts of past trauma surfaced between the cracks in the narrative.

\section{Forgetting is an attempt to heal trauma.}

If, as Ernest Renan says, "the essence of a nation is that all individuals have many things in common, and also that they have forgotten many things," the things that are forgotten still leave their mark. They may be buried deep in the national subconscious, but they still are missed. They are gaps in the national story. These gaps include aspects of the group's past that are too painful, embarrassing, or shameful to remember. When they are lost, that is when imagination and symbolism can step in to rebuild group identity. Even before the nineteenth century Irish left Ireland, they were already in the process of forgetting some of their past ways of living. Linguistically, economically, educationally, and politically, the lines had blurred between the Irish and their former colonial government. For the sake of following a British (capitalist) economic model, the way of life that went hand in hand with the Irish language, the communal living of the rural clachán, had largely been forgotten, too. David Lloyd describes the clachán system of communal farming as close living quarters that promoted sharing of culture, through stories, song and dance. Before the Famine, according to Lloyd, the Irish land was organized this way. Small cottages 
abutted one another, and pastures for grazing were shared; there was no need to mark ownership of property. Repairs on buildings were done together, and the purpose of work was to have just enough to be fed, clothed, and sheltered. The lack of a need to accumulate capital left time for gathering with family and neighbors, sharing songs and stories. To the British capitalist this system did not look organized at all (Lloyd Irish Times 41-42). Lloyd's ongoing project through his Anomolous States (1993) and Irish Times (2008) is to show how nationalism repeats the modernizing impulse of "progress" and "development," eliminating what he repeatedly calls "recalcitrant" elements of the culture that resist integration into a capitalist model. The communal living of the clachán system was essential to the dissemination of Irish culture from one generation to the next. With the Famine, and the land consolidation that followed close on its heels to bring Irish farming more in line with a capitalist model, that important vehicle for cultural survival was lost.

Or was it? These elements of nation that are strategically forgotten find ways of popping back up. According to Kiberd, playwright Brendan Behan found communal living on the Blasket islands (the last, relatively untouched Irish community), similar to what he experienced growing up poor in Dublin (490). It is not at all unlikely that the clachán community of the Blaskets was replicated by the rural folk forced off their farms into crowded city living in the Dublin slums. They were still poor, they were still looking out for one another, and they were likely still singing and telling stories when they could. Similarly, Peter Quinn finds that in America the Irish crowded into urban ghettos because, "crowding was part of who they were" (80), and he attributes this to their having come from the clachán system. 
He describes the clachán as "a clump of cabins that leaned on one another, a physical embodiment of the tight-knit community built on a communal method of land distribution" and says that "outsiders often remarked on the intense conviviality of the clachán, the incessant emphasis on singing, dancing, and storytelling that wasn't merely part of Irish culture but its living heart, the vessel of its survival" (80). Historian Timothy Meagher, too, discusses the communal living of the Irish upon arrival in the United States, saying that it might have actually held them back from prospering more quickly. He says the Irish lacked, "the kind of individual ambition and entrepreneurial values that were vital to workers trying to move up in a capitalist industrial economy" (48). This is only a negative, of course, when one is forced by circumstances to live in a capitalist economy. As Irish-American literature surveyed in this project shows, there was a social and a psychic cost to pay for those who chose to put the individual before the communal, especially in the early days of IrishAmerican life.

Among Irish Americans today it would be difficult to find many who know a word of Irish (which they most often would call Gaelic), beyond the Erin go bragh they hear on Saint Patrick's Day, or the occasional Céad Míle Fáilte sign overhanging a home or office door. It would be even harder to find one who had heard of a clachán. Once the Irish in America left their crowded urban communities for the suburbs, they would be closer to American individualism than Irish communalism. The myths and origin stories Renan speaks of as the basis of nation building are also lost to the descendants of immigrants. In the new country children begin to learn of their own heroes: Johnny Appleseed replaces Cúchulainn, and Harriet Tubman trumps 
Grace O’Malley. Public schooling ensures that the children of immigrants will be American national subjects, not Irish. Anxiety ran high for nineteenth century Irish parents in Boston, where they believed in the public schools, "teachers were using educational techniques to undermine the traditional Roman Catholic faith of their children," including insisting on the use of the Protestant King James edition of the Bible and the reciting of Protestant prayers (O’Connor 80). Even the parochial schools largely established and attended by the Irish in America in response to such concerns about public schooling saw to it that their pupils were educated as American citizens. There they would not only sing Catholic hymns, but also the American National Anthem and other patriotic songs. Irish rebel songs and other music would have to be learned at home if at all. The Irish language, the way of life of the clachán, and the shared vision of Ireland's heroic past have for the most part been forgotten in Irish America. They are elements of a way of life that has been long-since left behind. What are the psychological reasons for, and ramifications of, this kind of cultural forgetting? Studying the theory of memory and forgetting reveals some clues. Maurice Halbwachs famously theorized memory as a collective process: "the greatest number of memories come back to us when our parents, our friends, or other persons recall them to us.... It is in society that people normally acquire their memories. It is also in society that they recall, recognize, and localize their memories" (38). How disorienting the immigrant experience must be in light of this collective view of memory. Immigrants are cut off from many of the people who share and help them recollect their memories. If we remember together, we lose our past when we separate from those who share it with us. Distance from family and neighbors left 
behind accounts for some gaps in memory. Another break down in memory comes from a loss of language. Halbwachs calls language "the precondition for collective thought." Language and the social system attached to it "allows us at every moment to reconstruct our past" (173). For immigrants who leave a native language behind, then, there is another disconnect with memory. Granted the Irish and many immigrants who followed tried to reconstruct their communities in their new country. Staying in crowded urban ghettos likely provided a sense of comfort to them. It is no wonder that immigrants would choose to settle amongst people from the same country, and even from the same county or region when possible. It must be horribly isolating to feel one's past slipping away.

Halbwachs also explains that we privilege some events of the past, depending on the demands of the present: "Society from time to time obligates people not just to reproduce in thought previous events of their lives, but also to touch them up, to shorten them, or to complete them so that, however convinced we are that our memories are exact, we give them a prestige that reality did not possess" (51). This would account for how memories of home become tinged with nostalgia, when what one needs is the comfort those more positive memories bring. The needs of the present change the story told of the past, leading to a form of forgetting that may leave out some details while cherishing others. If this can happen in the immigrant generation, imagine how the story can change as these memories are passed on. It is like a game of "telephone" told through the ages, with each generation remembering what meets its needs at the present time. In that process some details are passed on 
faithfully, some are misconstrued, some are made up, and some are forgotten altogether.

Paul Ricoeur differs from Halbwachs in that he sees memory as not just collective, but a series of exchanges "between the living memory of individual persons and the public memory of the communities to which we belong" (131). Still, memories are tied to communities as half of that exchange in Ricoeur's theory. Leaving one's community then is a disruption in memory. Though we often think of memories as things we can carry with us, Ricoeur shows that they may not be easily portable:

It is on the surface of the habitable earth that we remember having traveled and visited memorable sites. In this way, the 'things' we remember are intrinsically associated with places. And it is not by chance that we say of what has occurred that it took place. It is indeed at this primordial level that the phenomenon of 'memory places' is constituted, before they become a reference for historical knowledge. These memory places function for the most part after the manner of reminders, offering in turn a support for failing memory, a struggle in the war against forgetting" (41)

Emigrants leave behind their memory places - the favorite pub, granny's cottage, the farmland they worked, the school or dancehall where they first fell in love. Leaving behind these places must have caused emigrants who could not return to feel they were losing "the war against forgetting" as faces and places faded into the past. For Ricoeur memory has an imaginative function, in that we put our experiences into images. He admits that this gives memory a credibility problem (53-55). When memory is made part of a narrative of identity, it can break down even more: "It is...the selective function of the narrative that opens to manipulation the opportunity and the means of a clever strategy, consisting from the outset in a strategy of forgetting as much as in a strategy of remembering" (85). As with Halbwachs, here 
Ricoeur is showing that the needs of the present can cause distortions in what is remembered and what is forgotten.

In Catherine Nash's work on the popularity of genealogy amongst members of the Irish diaspora, she, too, explains that memory is tied to places. Specifically, for Nash, memory is tied to land. Nash's work is a reminder to include the loss of land on the list of traumatic experiences. Disinheritance of the land through colonization, forced eviction, and emigration would have been among the earliest traumas the Irish carried with them. Nash examines what it means for third, fourth, and even beyond fourth-generation descendants of Irish migrants to go searching for their "roots." She points out that even the language of genealogy (roots, family trees) is land-based. Those conducting genealogical investigations are often interested in visiting the places their ancestors left a century or more before, because "Having a genealogical connection to a place and the cultural forms associated with it is a routine guarantor of the right to say "that is my culture"” (Nash 181). While Nash points out that there is no such thing as pure culture, as different groups have always come and gone and mixed even from "Old World" places, she says that this quest for connection to one's ancestral land "reflects a nostalgia for an imagined time when place, identity, culture and ancestry coincided. Where you lived was where your ancestors had lived and there was no dissonance between cultural identity and location" (179). This is the Ireland of intense attachment to place described by Eamonn Wall. The uprooted Irish in America would certainly have felt that dissonance between where their families had lived for generations and where they wound up in the busy cities of the United States. 
As Arjun Appadurai explains, traditional modes of cultural transmission are interrupted in migrating peoples. This inevitably leads to cultural forgetting.

Friedrich Nietzsche puts a positive spin on forgetting. He says that while memories keep us chained to the past, forgetting frees us (87). Animals have a more enviable state, as they instantly forget; they can live without history, but "The human being...braces himself against the great and ever-greater burden of the past; it weighs him down or bends him over, hampers his gait as an invisible and obscure load that he can pretend to disown" (88). In order to live, per Nietzsche, we have to forget. This explains what the Irish did when first entering the United States and for some generations after; they forgot so they could live. They had to forget the conditions they left behind, the people and culture they left behind, and their memory places, in order to begin an American life. It is only in later generations, in fear of losing an Irish dimension to themselves altogether, that they tried to reassemble those memories. Homi Bhabha tells us that "Remembering is never a quiet act of introspection or retrospection. It is a painful re-membering, a putting together of the dismembered past to make sense of the trauma of the present" (Location 90). Gayatri Spivak defines nationalism as, "the product of a collective imagination constructed through rememoration" (288). Re-memoration indicates more than just remembering, but also a reconstruction or rewriting while remembering. By the time the Irish in America were ready to re-member, there were many gaps in the memory chain that needed to be filled in. As is often the case with those suffering from trauma, those gaps would be filled in with a more pleasant version of events. 
Sigmund Freud would tell Nietzsche that no matter how we "pretend to disown" our past, however, it will still be present, if buried, in our lives. Things we have forgotten have ways of popping back up until we are ready to deal with them. Freud says of the goal of psychoanalysis in its third phase (around 1914), "Descriptively speaking, it is to fill in gaps in memory; dynamically speaking, it is to overcome resistances due to repression" (148). Though Freud is writing about individual psychology here, Halbwachs and Ricoeur allow us to make the leap to collective memory. This study will explore the gaps in the Irish-American narrative and what caused those gaps. It is important to consider why we remember what we do, and why other memories are repressed. Gaps in the Irish story were created by the Famine deaths, but also from emigration that separated the Irish from their home country and culture, as well as the colonialism that had already begun that separation at home. Upon arrival in America, the Irish would have wanted to repress memories of starvation, of poverty, of being seen and treated by their colonial government as a subspecies, the embarrassment and shame of being poor. These repressed memories were covered over with the American success story as the generations went on. The origins of that story were remembered — that the Irish were up against great odds, both at home and in America. The origins could be remembered because it made the rise to success even more spectacular. The fighting Irish were not just involved in street brawls; they were in a fight for their lives in a new country.

The process of selective forgetting described by Ricoeur has driven the ethnic identity formation of the American Irish. Regarding the Holocaust, Dean Franco argues that "A catastrophic event without redemption which poses a challenge to the 
very conventions by which we understand history has become overwritten in American culture with the narrative of hope and renewal" (33). Irish Americans, too, have overwritten their foundational catastrophic event, the reason for the first mass exile from home, with a narrative of hope and renewal. The Famine has been rewritten as the first chapter in the American Dream for the American Irish. This forgetting or at least repurposing of a foundational trauma cannot be without its consequences. Franco claims that "In ethnic American literature, the erasure of the ancestral, through murder, genocide, enslavement, and the eradication of cultural memory, is precisely the trauma that must be worked through" (59). That trauma of the past must be worked through in the present, and Franco finds critically reading ethnic American literature an effective way to do that. He says, "We read and interpret the gaps of the past because the gaps in our present text compel us to" (173). Literature can help us fill in the missing pieces to our story. That is exactly what this study of Irish-American literature aims to do.

If the Irish-American narrative can be compared on the collective level with an individual's life story, the early years in America are the childhood; the years in Ireland are the infancy. As Benedict Anderson points out, the early childhood must be narrated for the adolescent, because the adolescent cannot remember it. Freud calls this the "familiar childhood amnesia" and says that what is forgotten in this amnesia is "completely counterbalanced" by what he calls screen memories. He says, "Not only some but all of what is essential from childhood has been retained in these memories. It is simply a question of knowing how to extract it out of them by analysis. They represent the forgotten years of childhood as adequately as the manifest content of a 
dream represents the dream-thoughts" (148). Screen memories are a screen put up to block the full memories of early childhood. Resistance to uncovering the true memories happens because the screen memories are so pleasant. We do not want to give them up to plumb what is underneath, which is more painful. However to know ourselves fully we must plumb those depths. The Irish-American narrative of upward success toward the American dream should be examined as a screen memory. What painful memories does it hide?

\section{Re-membering Irishness}

Generations after leaving the hunger and poverty of home, the Irish in America had to find ways to re-member their past. With each generation in America, Ireland receded further into that past. Nostalgia for their beautiful Emerald Isle became a screen for memories of a painful existence. Also painful would be the perception of having turned their backs on their Irish culture. American opportunity has a seductive pull. Irish-Americans in the twentieth century especially began to climb up the socioeconomic ladder. Yet that force, the pull of America, would have an equal force of fear of anonymity, of blending in to the larger white world with no unique identity to claim. When the descendant of the immigrant finally feels comfortable as an American, he or she can start to hand pick aspects of an Irish identity to remember. Margaret Hallissy explains that it is the third-generation American that is likely the first in this position of comfort: “The emigrant generation's story was about survival in a new land; the second generation's story was about assimilation, making that land accept them as 'real' Americans. The third generation, secure in its American 
identity, can explore the part of themselves that is Irish" (7). In this Hallissy echoes Marcus Hansen, who famously said, "'What the son wishes to forget, the grandson wishes to remember"' (qtd. in Gerber and Kraut 105). There is a risk, in this kind of identifying with Ireland, of misunderstanding what being Irish is so long after any first-hand connection had been forgotten. Hallissy quotes musician Bob Geldof as saying, "I am Irish and Irish Americans always irritate me. They pretend to be Irish when in fact they are Americans through and through" (1). Misunderstandings abound when, due to the time between the identification and the actual physical link to Ireland, there has been at least two generations, the first one likely being quiet about the trauma they had endured at home, and the second embarrassed about what their parents had endured and too busy trying to prove they belong in America to hold onto Irishness. There is too the fact that while so many left Ireland (1.5 million during the Famine years alone), many others actually stayed. Ireland continued to change, continued to experience its own history, after the emigrants left. While emigration is a large part of that history, the descendants of those who left were no longer experiencing the Ireland of the present. They had in mind the Ireland that the immigrant generation brought with them, or at least the bits and pieces of it that were passed on.

In some ways the vision of Ireland for Irish America stays stuck in a sentimentalized, nostalgia-tinged past, and worse yet, infused with the very stereotypes that greeted the Irish in this country (stereotypes reminiscent of the image the English had of them at home). It takes work for an American to connect with an authentic Irish identity, if such a thing exists, when so much has been distorted by both 
positive and negative forces over time. It is memory work based not on one's own memories, which are already suspect because partially imagined, but on memories passed down the generations. Shaun O'Connell writes of Irish Americans in the twenty-first century, "Perhaps, now, all of those who think of themselves as Irish fall into the category of the Irish Diaspora-citizens of everywhere, at home only in an Ireland of the mind" (252). He says that at this point "it is clear that the principal traits for those who call themselves Irish-American... have sufficiently eroded to make IrishAmerican identity less an inescapable heritage and more an elective affinity" (254). J.J. Lee echoes this idea, saying "it is likely that except for those who work systematically to sustain it, consciousness of an Irish dimension of their lives will be confined mainly to the immigrant generation itself, and perhaps to the second and third generations, and even many of those will have begun to melt into the American mainstream" (37-38). To varying degrees, then, people choose to maintain a sense of themselves as Irish, or Irish American, or they let that part of themselves go. Also to varying degrees, those who claim an Irish identity can make an effort to connect with the music and literature of Ireland, to study its history and its language, or they can resort to simple essentialisms based on the stereotypes of old. There is no one way to be an Irish American, and this study will not attempt to define one. What is more important here is the process used for re-membering or rememoration, and what that process leaves out, creating gaps and fissures in the narrative.

Both Pierre Nora and Bernard Stiegler theorize that memory needs external reminders. For Nora this is because with the disruption of the traditions of rural France, there is no living memory. Instead lieux de mémoire, or sites of memory- 
landmarks, monuments, flags and other emblems — are required to keep memory alive in ways he says were never necessary before modern times. Nora's theory is problematic in that it sentimentalizes the pre-modern, rural population, but his work is useful here in that it again ties memory to places, and talks about the disruption of traditional transmission of culture. Where a constructed history has replaced living memories, "Places, lieux de mémoire, become important even as the vast fund of memories among which we used to live on terms of intimacy has been depleted" (6). Because emigrants cannot take the sites from home with them, they have to find more portable lieux de mémoire. In Irish-American homes in New England through the first half of the twentieth century, there were three items likely to be owned and prominently displayed: a painting of the Sacred Heart of Jesus; the speech of Robert Emmett, martyr for Irish freedom; and an Irish songbook (Clark 6). While Nora would likely call these items lieux de mémoire, Bernard Stiegler would call them prosthetics for memory. They are memory aids for a population distanced from their homeland. Those particular three items represented for the Irish in America three of their longest lasting cultural inheritances: their Catholic faith, their bitterness against the English whom they blame for their displacement, and their love of often sentimental Irish-American music. Stiegler explains that memories such as these are not passed down genetically. The use of technics, or tools external to our bodies, are what makes us human (135-38). Language is one of those tools that exists outside of the body (155-56). Without these exterior tools or prosthetics, we could not have cultural memories. What the emigrants could take with them would help them remember Ireland, but in the early years of Irish immigration to the United States they 
would not have carried much. When economic comfort was achieved by later generations born on American soil, some reminders of Ireland could have been purchased. The question then becomes, would those have been reminders of an Irish identity, or an Irish-American identity?

The most notable marker of Irish-American identity proves not to be Irish at all. It is the way Americans have come to celebrate Saint Patrick's Day. A holy day in Ireland, Saint Patrick's Day in America "came to be a vast, largely secular celebration of ethnicity with parades, dances, banquets, and communal liquor drinking as well as high mass" as early as the mid-nineteenth century (Conzen et al 91). Today most of those elements are still present, except for the high mass. This celebration in the nineteenth century and today involves symbolism meant to bring an ethnic group together. According to Kathleen Neils Conzen and her cowriters, "What emerges as important in this process is not how much of the traditional culture has survived, but rather the changing uses to which people put cultural symbols and rituals" (97). Like the Italian-American festivals these authors also describe, Irish-American rituals around Saint Patrick's day can be read as a "psychological defense against the...faceless anonymity... of America" (97). Starting with a need to express Irish pride while they rose in America, these parades and celebrations often do still promote Irish culture at its best, teaching those who rarely think about Ireland for the rest of the year about its history, music, and dance. They can also devolve into contests about who can get the drunkest, and who can wear the most green, from green antennae to tutus and leprechaun hats. Reading Irish literature of the twentieth and early twentyfirst century can teach us how an ethnic Irish identity has evolved in the last 100 years 
in an ongoing process that "does not necessarily ever end" (Conzen et al 87), and what about our past has caused us to fill in our present in such interesting ways.

\section{Outline of This Project}

The Irish-American texts used in this study, based in small New England cities, as well as the major urban hubs of Boston and New York, can shed light on how the popular version of the Irish-American narrative came to be. In other words, from this literature, both fiction and memoir, can be gleaned an Irish-American ethnic identity as it was constructed, known, and understood in the $20^{\text {th }}$ century, the remnants of which still exist today. For in these most concentrated areas of Irish immigrant settlement, what became the Irish-American narrative was formed. By examining how this narrative was formed, we can learn both about the Irish in America and how immigrant and ethnic groups more generally tell their stories, against a backdrop of resistance to their arrival and attempts at ascendance above the bottom rung of the socioeconomic ladder. The Irish in America constructed a narrative in part in response to the lost language, lost culture, lost home place. One aim of this project is to show how this traumatic baggage has marked the Irish-American narrative from the start. It is a narrative of trying to retain some sense of Irishness in a place where, at least at first, being Irish is devalued. That narrative started in a British-controlled Ireland, and continued across the ocean in America. Irish-American literature shows the tension between disdain for the majority culture that rejected early immigrants, and the desire to be accepted by that majority culture, if only as a means to move up and out of the ghetto. It is a tension between assimilation and maintaining a sense of an 
Irish self, though what exactly that self was may have been distorted over the years. It is no surprise then that the texts involved in this study are all in some way about examining self, through fiction and memoir aimed at understanding one's personal and cultural identity.

Chapter 1 discusses two novels of the immediate post-World War II years, which themselves look back to an earlier time in the $20^{\text {th }}$ Century at the disintegration of the once concentrated urban Irish-American parish. These are novels by Irish Americans reflecting back on the turn of the century communities of their youth, communities built on the values of their immigrant grandparents. Novelists Edward McSorley and Mary Doyle Curran try to capture communities that are fading away as the Irish blend into American whiteness. These novels show an anxiety over the loss of connection to Ireland, with the immigrant generation dying out, and those who remember them and what they stood for aging. As these novels are being written, "the parish" communities where immigrants and their immediate descendants lived are fading into the past. The two novels covered here, Edward McSorley's Our Own Kind (1946), set in Providence, Rhode Island, and Mary Doyle Curran's The Parish and The Hill (1948), from Holyoke, Massachusetts, both feature young protagonists with close relationships to their Irish immigrant grandfathers. It is through these grandfathers that they know Ireland and Irish ways.

As works of fiction, these novels employ some wishful thinking in the form of a sentimentalizing of the immigrant generation. They ascribe to that generation values of generosity to the poor (even poorer than themselves), a willingness to speak out against oppression of any kind, and a belief in the spiritual and supernatural. The 
authors see Irish Americans moving away from these standards, and thus at risk of losing what about them is Irish. The fear is that if these values are forgotten as the Irish rise in America, they will become bullies to those beneath them, consumed with money and individual success, with little regard for the community. They also see some members of the second and third generations espousing a cold Catholicism that mimics American Protestantism, without the spirituality and warmth their Irish Catholicism once had. In fact, all of the negative traits these authors see the Irish picking up are attributed to emulating the American "Yanks," as they call them, in order to fit in and prosper. Doyle Curran writes a particularly scathing series of character sketches illustrating what the Irish in American will become if they forget themselves. Since she is looking back at least two decades from the time she wrote the novel, it seems this is her picture of what the American Irish by mid-twentieth century have become.

Chapter 2 moves into fiction of Elizabeth Cullinan, written in the 1960s through the early 1980s, when Irish Americans, especially the women, were just starting to feel their way into professional careers. Cullinan's two story collections, The Time of Adam (1971) and Yellow Roses (1977), and her two novels, House of Gold (1970) and A Change of Scene (1982) mostly feature female protagonists in their twenties and thirties, living in or around New York City and occasionally traveling abroad in Ireland. She repeats these characters and their plotlines, moving through different stages of their lives from childhood to early adulthood, and sometimes shifting the spotlight to other members of the family. The young women protagonists have forgotten their Irish roots in part because their middle class mothers are ashamed 
of them and want to hide them. The mothers in Cullinan's stories are interested in respectability and social climbing, while the fathers, to whom the narrators attribute their ties to Ireland, are weighed down with money problems due to drinking and gambling. Here Cullinan's writing marks a difference from McSorley and Doyle Curran, as the most favorable traits in the earlier works by those authors are assigned to the Irish characters. The negative traits of Cullinan's Irish-American fathers come close to perpetuating long-held stereotypes against the Irish. Cullinan is also a thirdgeneration American, but about twenty years younger than McSorley and Doyle Curran. Rather than having spent her childhood in a community that valued the contributions of its Irish immigrants, Cullinan admitted in an interview that her family did not want to be associated with being Irish: "Mother hated the Irish. We were supposed to be above all that" (qtd. in McInerney 99). Given the social aspirations of the mothers and the money problems of the fathers in Cullinan's stories, it is not surprising that the parents of her young women characters are often separated.

The divided identities of Cullinan's young women characters are reflected in the divisions between their parents, which in turn symbolize Irish Americans being torn between the Irish and American aspects of themselves. Cullinan's characters inhabit liminal spaces - almost but not quite let into the American professional world they desire to enter, or the Irish communities to which they travel. They are seen as American when they travel to Ireland, and as foreign and exotic when they try to make their way in the white collar business world of New York City, which in the 1960s was still largely Anglo-Protestant. They often have an insider/outsider status at one and the same time. They are forever on the threshold, until the end of her final novel, 
A Change of Scene, in which a more integrated and self-assured protagonist has finally made a successful career for herself and can claim New York City as her own.

As the evolution continues through the 1990s, as the distance of time from Ireland grows greater, the assimilation to American life becomes more complete, and the Irish diaspora becomes harder to recognize in the midst of suburban sprawl than they were in urban ghetto. There is at least one concentrated Irish-American neighborhood left well into the twentieth century, however. Chapter 3 looks at memoirs by Michael Patrick MacDonald, All Souls (1999) and Easter Rising (2006). MacDonald tells the story of the Irish who are still in the projects of South Boston when he grows up there in the 1970s into the 1990s. The Irish of MacDonald's South Boston, or Southie, as it is called locally, disrupt the narrative of rising to success in America. They are stuck in a neighborhood decimated by gangs, drugs, and poverty. MacDonald's memoirs provide a useful counter narrative; they expose elements the more popular version of the Irish-American narrative leaves out. As MacDonald directly tackles the question of his troubled neighborhood's proud connection to its Irishness at the exclusion of all others, his work serves as a window into how IrishAmerican identity has become one of symbol over substance, as well as a screen for the pain of being denied access to the riches of America.

When examined against the earlier fiction by McSorley and Doyle Curran, MacDonald's memoirs can be a place to find a more substantive Irishness than the shamrock tattoos and green clothing favored in his neighborhood could reveal. Again in MacDonald's memoirs, in the figure of his mother, especially, one finds the generosity, the resistance to oppression, and the spirituality that the mid-twentieth 
century writers feared was being lost. MacDonald also finds a deeper understanding of his own Irishness when he travels to Ireland and learns that the racism he associates with being Irish in Boston is not an inherently Irish trait. This trip and another one he takes later with his mother make up the last third of Easter Rising, the book he says he wrote to explain how he escaped the fate of so many of his contemporaries in Southie who died young due to drugs, gang violence, and suicide. Punk rock music is his first source of escape, as it takes him to different parts of Boston and later to New York City, California, and eventually Europe. It teaches him that not everyone is like the people in Southie. It is Ireland, though, that teaches him to understand himself, his mother, his Irish-born grandparents, and the history that has made his neighborhood what it is, for better or for worse.

Finally, Chapter 4 tackles the perspective of Irish-American identity formation from the Irish side of the Atlantic. Roddy Doyle weighs in on this process in his novel The Dead Republic (2010), a work of historical fiction - the third in his The Last Roundup Trilogy that spans the twentieth century and the first decade of the twentyfirst. The trilogy follows protagonist Henry Smart, born in 1901, a soldier for Irish freedom by 1916, and then a rebel on the run from his former Irish comrades in America from 1922-1951. The Dead Republic shows Henry Smart's ultimate return to Ireland, and along the way deconstructs how the Irish and Irish-American narratives have been created throughout the twentieth century. It does so through a fictionalization of the writing of John Ford's famous film, The Quiet Man (1952). If any one film embodies the way Irish Americans remember Ireland, it is this one. It is the screen memory of Ireland writ large. The film both plays on popular stereotypes 
of Ireland and Irish people, and solidifies them in the minds of its many viewers. It is not a coincidence that this film is written and produced in the same era that saw the publishing of McSorley's Our Own Kind and Doyle Curran's The Parish and The Hill. It comes out of the same mid-twentieth century anxiety about preserving a favorable Irish identity. Doyle paints the writing of Ford's film not only as an exercise in American nostalgia, but also as an act of collusion with an Irish Republican government seeking a unified Ireland and American tourist dollars. Doyle's novel is a meta-narrative of national and ethnic identity formation, and as such the perfect ending to this project.

Irish Americans who seek out an Irish identity need to look back and say they are part of the Irish nation. Even if it is a myth, they need that myth to understand who they are. Without their Irish anchor, they feel set adrift in the larger American culture, without any claim to ethnic uniqueness. The process of ethnic identity formation still continues, as the more than 33 million people who claim Irish ancestry in America grapple with what makes them Irish. The literature surveyed in this study will help us understand the competing forces that have gone into the writing of the Irish-American narrative. As with all narratives, there has been at least as much forgotten as remembered in its creation. It was a narrative constructed to heal psychic wounds of the trauma of being devalued by a colonial government and then of leaving home, to create a vision of a homeland that would ultimately heal those wounds. It is a story that justifies what the Irish in America have done, and what they have had to give up, to get where they are in a way that makes them proud of who they are. It is a 
story that provides one example of the process of ethnic identity formation in the United States. The study itself will fill in a gap in the scholarship on the Irish national narrative, by telling how the story continued when the emigrants left. Their narrative did not end when they boarded boats, and later planes, to come to America. The IrishAmerican narrative is both a part of the Irish story, and a part of the American story. It is a product of and a contributor to both. It is the narrative of a nation in diaspora. And it is still being written. 


\section{CHAPTER 1}

\section{Irish Skin, Yankee Masks: Post-World War II Novels and the Assimilation of the Irish-American Community}

There were, it is true, a few Irish on Money Mole Hill; and they were the worst of all, imitators of imitators, neither Yankee nor Irish, but of that species known as the lace-curtain Irish. They put the curtains up in their parlors, and decked out their souls in the same cheap lace.

-- Mary Doyle Curran, The Parish and The Hill, 18-19

Once concentrated in urban ghettos and later working class neighborhoods surrounding thriving Catholic parishes, the Irish in America after World War II were ready to make the move to the suburbs. After 100 years in this country, for the first time Irish Americans would spread beyond close physical proximity of other Irish. In one way this signaled that they had made it — they had finally been accepted into the American mainstream, and into the middle class. They, by and large, had fulfilled the American dream. The Irish-American narrative is full of pride in this rise to American success despite the poverty and oppression that drove them from Ireland and greeted them when they first arrived in America. In rising, however, they had lost the safety net that was their Irish neighborhoods and, perhaps worse still, they had lost what defined them as Irish. This loss provoked anxiety over blending anonymously into the rest of white America, losing their uniqueness and perhaps losing their values along the way. This anxiety is shown in the works of Irish-American novelists from the mid-1940s to mid-1950s, who in their writing both strove to capture the IrishAmerican community of their grandparents that they saw fading away, and to construct an Irish-American identity that would re-member (to use Homi Bhabha's phrase), or reassemble what was lost. These authors are at the same time recording, critiquing, and constructing the narrative of Irish-American identity. They do so in a 
way that reflects the anxiety of the time in which they were writing at least as much as it reflects the time about which they are writing. By capturing what elements they see being forgotten from the Irish-American communities of their youth, they reveal gaps and fissures in the Irish-American story.

\section{Historical Background}

Before looking at changes that were happening in the 1940s, it is helpful to have a clear picture of what life was like for many Irish Americans at the start of the twentieth century, while keeping in mind that differences in region, religion, and immigration generation make it impossible to define one Irish-American experience. The Irish-American experience depicted in novels of the immediate postwar period by Edward McSorley and Mary Doyle Curran is an urban one, where neighbors lived crowded into tenement buildings or smaller multi-family houses. This is a reflection of the way the authors' grandparents' generation experienced America. Their apartments housed large families with many children, plus extended members, such as unmarried aunts and grandparents. The men in the families worked as laborers in the mills and foundries of New England cities at the turn of the twentieth century. As the families prospered, they may also have had in their ranks policemen, politicians, priests, clerks, and saloon owners. Women worked largely in the homes, where there was plenty to be done to feed, clothe, and minister to the health of their large broods. If they worked outside of their own homes it was as factory seamstresses or as domestic servants for other families, most often established "Yankee" (as characters in 
both authors' works call them) Anglo-Protestant families. A single woman whose family had increased financial means may have been a teacher.

Outside of hard work, the defining feature in the lives of these families was their local Catholic parish. The Church was the spiritual and often social center of the community, and where possible the provider of education for the young in parochial schools. J.J. Lee describes the parish as "a bonding unit for Irish Catholics, with the church — often the most impressive construction they could consider their own, built from their own dollars and cents - the psychological and the physical focal point of their communal identity" (27). In congregating so closely together the Irish in America were replicating the clachán system of communal living they had experienced in rural Ireland (Quinn 80). The American version of the clachán was a crowded urban neighborhood. Valuing communalism over individualism, according to Timothy Meagher, "was a mixed blessing” for nineteenth century Irish immigrants he studied in Worcester, Massachusetts. Meagher explains, "Communalism was not very helpful in a society that favored individual ambition and risk-taking, but it softened the blows of a harsh urban industrial world as well, offering family or community strategies for survival even as it helped retard individual mobility" (22). In subsequent generations this communal structure would be left behind, but at an emotional cost. The Irish in America at the turn of the twentieth century were able to still pass down stories, traditions, and values in a way that approximated what they had done in Ireland. That would soon be changing.

David Lloyd often points to "recalcitrant elements" in Irish life that refuse to be assimilated into its supposed modernity (Irish Times 4). Those who are disturbed 
by these elements or even those who view them nostalgically "have sought over and over again to fix, with all the ambiguity of that term, the remnants of other times that appear as the signs of Ireland's incivility" (Irish Times 1). These elements were also expected to be lost upon assimilation into American culture. Irish Americans in the mid-twentieth century would have been proud to be Irish, as long as being Irish did not mean being backward. They would have judged those backward elements as belonging to another time. Those who have constructed the Irish-American narrative to leave out Lloyd's “recalcitrant" elements are like Nietzsche's monumental historians, who have caused the past to be "damaged" with "entire parts...forgotten, scorned and washed away as if by a gray, unremitting tide, and only a few individual, embellished facts rise as islands above it" (100). The poverty in which Famine and post-Famine immigrants arrived, and the stereotypes hurled at them as a result, would need to be forgotten in order for the Irish to move up the American ladder of economic success. The fact of this rise would be the story embellished, rising as an island above what was by necessity forgotten in order to blend in, including an inclination for communalism over capitalism, a belief in the supernatural as part of our world, and a conception of time that saw history as alive in the present.

Up until just beyond the turn of the century, the urban ethnic communities inhabited by the Irish in America still had a steady stream of immigrants from Ireland to refresh their ties to the homeland. By the 1920s, there were enough immigrants who came in waves in the late nineteenth century still living to give the neighborhoods a strong connection to Ireland. These were the grandparents, the story tellers, the keepers of tradition. The children of the nineteenth century immigrants were now the 
parents of the third generation Americans attending parish schools. A series of changes to the demographics of these communities were about to take place, however. The two world wars, and restrictive immigration laws put in place in the 1920s, curtailed immigration from Ireland to the United States significantly, cutting it down to a trickle compared to what it had been for the previous 70 years since the Great Famine (Kenny American Irish 182). For Irish Americans born in the first two decades of the twentieth century, as were authors McSorley (1902) and Doyle Curran (1917), the change in their communities' makeup would have been striking. By the time they were writing in the 1940s, "the demographic profile of the Irish-American ethnic group was transformed" (Kenny American Irish 228). Per historian Kevin Kenny, "The 'graying' of Irish America, along with the rapid reduction of immigration from Ireland and the exodus to the suburbs, was in large part responsible for the significant diffusion and erosion of Irish-American ethnicity in the second half of the twentieth century" (228). J.J. Lee echoes this idea, saying that by the second and third generations in this country, the Irish "have begun to melt into the American mainstream" (38).

In addition to demographic trends that saw fewer Irish immigrants coming into urban communities, established Irish Americans now had more opportunities to leave their city neighborhoods for newly built suburbs. The G.I. Bill of Rights provided education to returning Irish American soldiers who otherwise would not have had access to higher education, as well as low-interest mortgages, and other benefits (Quinn 41; Fanning 312). These benefits in turn opened up to these (mostly) men and their families income and housing opportunities that had rarely been experienced 
previously by the Irish in America. Though Kevin Kenny says that the Irish showed a preference for city living that kept them in urban neighborhoods longer than other white Americans (American Irish 227), they eventually became part of the white flight out of the cities and into suburbia as they gained the financial means to do so. By this time, the Irish in America had become "emphatically an ethnic rather than an immigrant subculture" (Fanning 239). The story tellers and tradition keepers were fading into the past. Distance from other Irish-American neighbors exacerbated that loss. When Irish Americans finally did decide to move out of their city neighborhoods, "the substantial drift to the suburbs tended to fragment their sense of cohesive ethnic identity" (Kenny American Irish 227). If entering diaspora is a dispersal, moving out into American suburbia was like a second emigration, a further dispersal of the once concentrated Irish community. Even in the mid- to late-1940s, at the beginning of these trends, the authors in this study saw change in the air. It is no wonder they desired to capture what was being lost, in historical fiction that cast a backward glance to the time of their childhoods. Mary C. Kelly, who traces Famine remembrance (and forgetting) through 150 years of Irish-American history, claims that though there are not active, public Famine remembrances happening in the 1940s, "indications of awareness that a key dimension of Irish ethnicity now risked permanent disappearance within the ethnic culture may be identified" (97). Anxiety over losing key elements of Irish culture in America led to a creative outpouring that tried to capture an earlier age.

Since the Catholic Church was so central to the identity of most Irish in America, how the Church evolved over the generations is a central part of the Irish- 
American story. Controversial political scientist Samuel Huntington outlined the process through which Roman Catholicism in the United States became American Catholicism, as it "assimilated many features of its Protestant environment and was, in turn, assimilated into the American mainstream" (92). Huntington sees the assimilation as positive and necessary in creating one national identity based on Christian values and a strong Protestant work ethic. He says this change was happening by the mid-twentieth century, when "Catholic leaders such as Bishop Fulton J. Sheen and Cardinal Francis Spellman had become fervent American nationalists, and the Irish-American Catholic became the prototype of the patriotic American" (96). The drive to be seen as respectable in American eyes was behind this changing Church, as Catholics had to prove they were good Americans, loyal to the President as well as the Pope. The spirituality and enchantment of the faith the Irish brought with them to America would be one of the many elements of their culture forgotten as they assimilated in their new country.

\section{Two Novels in Conversation}

The novels studied in this chapter, Edward McSorley's Our Own Kind and Mary Doyle Curran's The Parish and The Hill, are constructed narratives of the places from which the authors came, beginning in the time period of their childhoods. As such they are a form of cultural memory, even if fictionalized. When one leaves behind both the community that helps him or her remember, and the place tied to those memories, it is then easy to forget. These post-World War II Irish-American novels have in common a clear mapping of the neighborhoods that are their settings, with 
street names and adjoining neighborhoods enumerated in detail. Moving from one's established neighborhood to another was a cause for distress. Forgetting who they are is a disturbing threat for those set adrift in a vast American landscape, without familiar cultural landmarks and friendly faces to help them remember. This is one thing disturbing McSorley and Doyle Curran at mid-century. We must not study these texts as historical documents of the period being written about, but instead as examples of the way "memory was produced, constructed, written, and circulated" in the time that they were written (Saunders 323). As constructions of memory, they "tell us more about the rememberer's present, his or her desire and denial, than about actual past events" (Neumann 333). Authors construct the past that they want to remember based on their needs at the time of writing (Neumann 334). For the Irish-American writers after World War II being studied here, that need was to capture a dissipating culture before it was entirely gone, as the move to suburbia was clearly on the horizon.

These authors also needed to re-member an immigrant generation they saw as relatively pure, and uncorrupted by American capitalism and racism, by virtue of having first-hand experience with Ireland. Some of the immigrants in the novels quickly adapt to the American way of doing business, but the beloved grandparents of the protagonists have been elevated to hero status. If anything is remembered nostalgically in these novels, it is these grandparents. The authors revere the Irish grandparents, assigning to them what they see as a more authentic Irishness, while critiquing some of the younger Irish-American generation who have lost their way through greed and callousness. These authors see a need to re-member what being Irish means. The world being remembered by these authors is also being created by 
them. In doing so they construct a narrative of Irish-American identity that meets the needs of a community on the verge of disappearing in the middle of the twentieth century. For Edward McSorley and Mary Doyle Curran that community had lost its way as it became Americanized.

The authors illustrate the anxiety over what was lost in Irish communities in McSorley’s Providence, Rhode Island, and Doyle Curran's Holyoke, Massachusetts. Their novels are told from the perspective of children, both of whom have special relationships with their Irish immigrant grandfathers. The immigrant grandparent figures provide moral instruction not only for their grandchildren, but by extension for the readers who take in their stories. Interestingly it is not Ireland being mourned so much by the authors of these novels, as it is the communities the Irish constructed when they arrived in the United States. Per McSorley and Doyle Curran, it is when American values (aligned with capitalist values) start infringing on the communal values of the clachán, reconstituted here as the Catholic parish, that the Irish in America start losing their Irishness. These authors show that as akin to losing their souls. When greed and status trump caring for one's neighbor it is seen as the ultimate insult to the Irishness being constructed or re-membered in these books.

The disintegration of concentrated Irish-American neighborhoods, through the lack of new immigrants and economic opportunities that allowed those established in the U.S. to move to the suburbs, caused anxiety because it was a repetition of earlier losses of culture. The Irish in America had already survived colonialism, the Great Famine, and emigration. All of these ate away at their ability to transmit their language and customs. In fiction that recreates the early Irish-American community, 
characters portrayed as most authentically Irish are always great story tellers. This can be traced back to the clachán, where upcoming generations were educated through talk — stories that passed on communal values, and taught life lessons. This is more than the gift of gab or mere entertainment, though it is highly entertaining; it is also an essential pedagogical method. With the fragmentation of the Irish-American community by the mid-twentieth century it is in danger of being lost. Suburbanization was viewed as a step up the American ladder of success, but it was also the final step in a long and often traumatic journey for Irish Americans away from their Irish roots. Both Our Own Kind and The Parish and The Hill show anxiety for the world in which their young protagonists, both third generation Americans, would grow up, and the values with which they were being educated. The authors are writing with the perspective of having seen the Irish America of the 1940s. This Irish America, still haunted by the specter of the Famine one hundred years later, is also haunted by the culture it has given up in exchange for American acceptance, assimilation, and material comfort.

McSorley and Doyle Curran see the Irish-American communities from which they came losing their identities and their novels may have been written at least partially as correctives before it is too late. These are novels of development that is ruptured, cut off, or even deformed. Especially in Doyle Curran's portrayal, the IrishAmerican community is experiencing a deformity as its members are changed grotesquely by greed and social climbing. Unlike traditional bildungsroman, neither novel has a satisfying ending where the reconciliation between protagonist and surrounding adult world has happened. Transmission of culture is not happening in 
natural circumstances here because the American world outside the Irish neighborhood is encroaching in the time period in which the novels are set (from about 1916-1929). This foreshadows the Irish starting to spill out of those neighborhoods into suburbia at the time the novels are being written (mid- to late1940s). The authors being studied here need to re-member what has been forgotten in their communities. While on the one hand this movement can be seen as a good thing - providing social mobility and comfort the Irish dreamed of when coming to this country - on the other hand it was a further disconnect from the culture they had left behind.

These novels from just after World War II are themselves like Pierre Nora's sites or realms of memory, as they preserve in the present what their authors see slipping into the past, at a time of cultural upheaval. Ned McDermott and Johnny O'Sullivan, the immigrant grandfathers in McSorley's Our Own Kind (1946) and Doyle Curran's The Parish and the Hill (1948), respectively, represent the Irishness that was being lost by the mid-twentieth century. These grandfathers both try to ensure that their grandchildren, Willie McDermott and Mary O'Connor, retain what is important of Ireland and Irishness. Both Ned and Johnny impart lessons to their favored grandchildren by the time-tested Irish method of storytelling. They tell stories of Irish heroes and an ancient Irish past. They want Willie and Mary to have pride in their Irish heritage, but not so much pride that they look down on others. They also teach moral value lessons on how to treat others both by example and by gentle reprimand as well. They will not put up with their young charges picking on anyone who has an even lower social status or less money than the Irish in America. Both 
Ned and Johnny have a keen sense of having quite recently been on the lowest rung themselves, and they prefer unity with other groups over separation. This is a lesson of which both McSorley and Doyle Curran are set on reminding their readers. Both grandfathers die before the novels end; their teaching of the grandchildren is not complete, representing the fractured social transmission in the new country and the unsatisfactory resolution of the bildungsroman. While living, however, they do their best to pass on their values to the youngest in their families.

Though Our Own Kind and The Parish and The Hill have these similarities of reflecting anxieties over assimilation during the time in which they are written, they are different in the way they are structured, and in the degree to which they feel the Irish in America have lost themselves. McSorley's is a coming of age story with a traditional plot structure: young orphaned boy, adopted by his hardworking grandparents, tries to overcome obstacles to his becoming a successful adult including an uncle jealous of the grandfather's affections and neighborhood boys who peer pressure him into getting into trouble with the law. Willie McDermott is the protagonist, and the novel proceeds through what seem to be his preteen and early teen years until, upon the death of his grandfather, he is left to make his way without his chief protector and advocate. Willie realizes by the end of the novel that the immigrant generation is dying and that his grandfather's insistence on educating the boy into a professional, respectable occupation will eventually make of him a stranger to his working class Irish community, and therefore to himself. The chief tension of the novel is how to balance an American education with retaining pride in an Irish past. The characters are complex, especially the grandfather Ned, who has a keen 
sense of justice, an unfailing work ethic, and a big heart, but also flaws that McSorley relates with humor. Ned wants two things in life: a free Ireland, and his grandson to show the Yanks that an Irishman can be their equal in intelligence and education. Aside from that, a drop of whiskey, a full pipe, and the companionship of his dog never hurt either. The sad ending is not overly sentimental, but leaves Willie and the readers with the question of what will become of him now that Ned is gone.

Doyle Curran's novel is different both in structure and in tone. The Parish and The Hill is a series of character sketches, one per chapter, starting with "the Parish" itself, the Irish-American immigrant and second generation neighborhood to which the author ascribes a largely undiluted Irish culture. Each chapter starts with the young narrator Mary O'Connor's proclamation, "I remember...." She remembers first Irish Parish, which is odd because she did not live there. She is remembering a time before she was born in the first chapter, an act that Marianne Hirsch might call a form of "postmemory." The reader never knows exactly how old Mary is, but after that first chapter the story follows her from preschool years (her first memories) to adolescence. In that sense it does have some sense of a chronological narrative, but as a series of sketches starting with the proclamation "I remember" and then describing a character, it does not move forward in a traditional way, rather circling back to the origin story of each character. In these character sketches, Doyle Curran can resort to caricature, especially in the depictions of the Irish American tendencies toward social climbing and bullying. These are two traits Doyle Curran clearly despises, and her social critique of them is the point of the novel. If there is a character in crisis, it is the IrishAmerican community. Mary O'Connor is just giving witness to its downfall. It is an 
ironic downfall in that it comes as members of the community are supposedly moving up in American socioeconomic status. Because her depictions of these negative types of Irish Americans are over the top to the point of being grotesque, and her portrait of Mary's grandfather Johnny O'Sullivan is so idealized, the novel is important more for its list of concerns about Irish America at mid-twentieth century than its aesthetic value. Unlike McSorley's Ned, there is little subtlety in the way these types are depicted by Doyle Curran. Looking at each of these novels individually can provide a better sense of just what their authors were worrying about in the middle of the twentieth century.

\section{An Irish American comes of age in a challenging world in Our Own Kind.}

When Ned McDermott takes his orphaned grandson Willie McDermott under his wing in Our Own Kind, it becomes his mission to see to it that his grandson will not become another soldier or laborer to give up his life or at least ruin his body for someone else's cause or profit. That mission is in jeopardy of failing when Willie gets in trouble with the law for breaking into a store with neighbor boys who are clearly heading in the wrong direction in life. Not wanting Willie to continue traveling their path, Ned decides to move the whole family to a different neighborhood, on the other side of Providence. This is a major move given how rooted Irish Americans are in their own parish. Ned will let nothing in the way of his goal, however. He wants to make of Willie a scholar, to enter him into a career where he will use his mind, not his body, and where he will earn good money, but more importantly where he will earn respect for all he knows. For illiterate Ned, reading is the key to Willie's success. In 
the new neighborhood, two priests and one kindly neighbor, who happens to be his uncle's fiancée, help Willie to continue his education and stay on the right path.

This desire of the immigrant generation to better the socioeconomic situation of their children and grandchildren led to a moral quandary being addressed by McSorley and other Irish Americans in the mid-twentieth century: Ned wanted Willie to be a successful, middle class American, so he would not have to labor for any Yankee boss. Yet in educating himself above the laboring class, Willie had no model to follow except the Yankee, and no one to remind him of the Irish heroes once Ned's generation is gone. The danger is that the Irish-American success story will resemble too closely the Yankee businessman, who values profit above all else. Realizing that Willie needs more Irish heroes than America can give him, Ned takes much of Willie's early education upon himself. Before Willie can read, Ned tells him stories from the funny papers about "great and gay and witty Irishmen who were always getting the best of it" (7), creating for the boy Irish heroes who do not actually exist in the local Providence or Boston papers he is "reading". Ned tries to construct an Irish narrative of success in America for his grandson. He needs to counteract the stereotypes he knows the Irish are up against in their new country.

Another hero Ned introduces to Willie is the martyr for Irish freedom, Robert Emmet. Ned early on convinces his grandson that he can read because he recites word for word Robert Emmett's dying appeal for a free Ireland: "When my country takes her place among the nations of the earth, then, and not until then, let my epitaph be written" (qtd. in McSorley 8). In a repeated ritual, Ned and Willie "read" Emmet's speech together. First Willie just listens, but as he begins to learn his letters in school, 
he follows along. Robert Emmet's framed speech on the wall is one way to ensure memory is passed on. Ned does not need to be able to read the speech; he has it memorized. He knows it "by heart" as the saying goes, and the sentiment the speech espouses is felt in his heart and soul. For Willie the attachment to Ireland is not so automatic. Unlike Ned, he needs the written speech to fully know it. The speech for Willie becomes what Bernard Stiegler has termed a "prosthetic for memory" (152). It is a memory aid necessary because the lived memory of Irish oppression is not internalized or passed on genetically, especially not in the United States, where Ireland's problems could be easily left behind for the generations born here. Ethnicity is not instinct. It must be learned through external tools, or technics, such as language. This is what makes us human (Stiegler 155-56). The Emmet speech is a handy tool for memory because it is easily portable. It hangs in every home Ned has in the United States. His speech hanging in the McDermott household symbolizes the need for Irish Americans to keep their memory of Ireland alive—of Ireland's struggles and of its fight for freedom. Emmet faced down oppression with eloquence to his dying moment. He would not give in. In remembering Emmet the Irish in America are remembering a pride in who they are, in a place that threatens to take that from them.

Ned is secure in his own Irishness without needing to read, but he is desperate to get Willie to read, not only to step up on the social ladder, but also so he can read about Ireland what he does not feel as Ned does; he can read Emmet's speech. Later, when Willie can read for himself, Ned bemoans the lack of Irish heroes in the books he brings home from the library. As Willie gets older and becomes an avid reader, Ned has him read newspapers to him, and has him summarize the stories he is reading 
in library books. Ned remembers all the details that are read or told to him, and criticizes the depiction of the Irish in Willie's books:

It seemed damn queer to him... that every Irishman in the books Willie got from the library was a damned fool or a drunk and there never seemed to be a Catholic born into the world except perhaps a Frenchman and what the hell did they amount to after all, anyhow.... But go ahead, and read them, read them all for the more you read the more you'll want to read and God knows there must be an Irishman hidden away in them somewhere that walked on his hind legs and had learned to speak more English than 'whisht' and 'begorra.' (138)

Notably these words that Ned credits to the Irish as English are barely English at all, with "whisht" being more of a dismissive sound and "begorra" a corruption of "By God.” That this Irish patriot should be so concerned with Irishmen speaking proper English shows how well colonialism did its job in Ireland. In all of Ned's desire to educate Willie, he never once hopes that he will learn to either read or speak the Irish language. In fact, that language is never even mentioned in Our Own Kind, an omission that may point to McSorley's understanding that even if the Irish in America could hold onto some of their fading values, they would never regain their original language. For Ned's plans to come to fruition, Willie needs to master not just the English of the streets, but the English of the elite classes. He must read, and read voraciously.

Ned is thrilled when he finally does hear a story of Irish heroism from Willie, not out of a library book but from a play put on at their parish church on Saint Patrick's Day. Because the Yankee owned and operated libraries would not stock books that herald the accomplishments of the Irish, the Irish would have to advance their own narrative in the place where they had control: the parish church. Willie goes to the church hall to see a matinee of the play of Irish rebellion against an evil English 
landlord. When he goes home and describes it to Ned, Ned declares that all of them (his wife and sister-in-law and Willie again) will go back and see the evening performance. The play further confirms Ned's view of the Irish: "What the Irish can't do.... What scholars and poets they are! What scholars, Willie! Ah, that was a grand thing! My boy, the talents the Irish has is—is unspeakable!" (169). What is unspeakable will leave a gap in memory, especially after Ned's generation is gone. This is why reading is key to retaining communal memory, but only if the community's stories are written down. In his fiction, McSorley is providing a record to fill in the gaps of memory left as these Providence Irish communities dissipated.

A common thread for the characters who best embody Irishness for both McSorley and Mary Doyle Curran is that they do not forget their humble roots, even as they remember their pride in being Irish. Because of this they stick up for other immigrants and oppressed people. For McSorley this character is Ned. Among other things, Ned wants to impart to Willie his compassion for the underdog, not only the Irish, but all oppressed or suffering people. In one moving speech, Ned slyly brings out of Willie a confession that the boy had participated in harassing an old Jewish man who walked through their Providence neighborhood. Ned draws parallels with the treatment of the Irish when they first arrived in this country, and explains how the "Yankees" used to spread horrible rumors about Catholic priests and nuns, and how they threatened to burn down a Catholic convent in Providence, and that they did burn one down in Boston. Ned was among the Catholic men standing there with a club to protect the Providence convent, he says. He asks Willie,

what is it, our turn now to be savages?... God damn it, Willie, is that what's to come of all the schools and the teaching? Sure we might have let the Yankees 
burn them down long ago and be done with it, if that all's to come out of it! ... Is the sisters teaching them in the schools that was built on pennies and nickels that might have bought bread to feed a hungry mouth to go tearing and slashing at a man in the street because there's a beard hanging on his chin or he talks in a strange way to them?... Thick as we are we're above that I hope, above raising a hand against a man because his faith is not our faith. (66)

This concern for the oppressed also makes Ned a strong union man. A union, for Ned, is not just a union for the Irish. He knows that all of the workers will be better off if they work together, not against each other as benefits the bosses. At Ned's wake, his brother Pat recalls a triumphant moment when Ned convinced his all-Irish union that the Italians should be allowed to join: "WWhat the hell, he says, is the Iron Moulders Union? What the hell right has it or you to bar any man out if it that works in the shop?"” (287). Ned drinks in a local pub with African Americans, and is even friends with one Protestant. "“There's good and bad in all kinds, you know,"” Ned explains. In the mid-1940s when McSorley is writing, he needs to re-member for Irish Americans who may be prone to ethnocentrism, that an Irishman can have pride and passion for his home country without being boastful or bigoted against others.

Somewhere along the way the Irish-American community lost this sense of balance, and McSorley is reminding them that they should get it back.

One surprising subplot in McSorley's novel takes labor organizing to a radical level. Ned's son Pat, only a marginal character for most of the book, is beaten so badly at a labor rally that he dies from internal bleeding. Before the beating Ned has been advised by his cousin Larry McDermott, a police lieutenant prone to brutality, that Pat was hanging out with undesirables of the socialist type. Larry McDermott does not want to see the system that allowed him to rise challenged. He scares Ned by telling him that socialists threaten to tear apart sacred institutions such as marriage and 
the Church. For Larry, "Thefts, rapes, sluggings, sometimes a murder, desertions of families, arson, violence of any and every kind were [his] daily fare... but for him Socialism was the cardinal sin, except for denying God himself, there was nothing in the calendar worse than Socialism" (205). Ned leaves the meeting with Larry confused about what socialism is. He certainly does not want Pat involved in anything that would threaten the Church, but he is also suspicious of the Church involving itself in politics. While Ned is confused, McSorley's irony shines through Larry's list of crimes he finds more acceptable than a peaceful protest for workers' rights.

Ned and most of the men he knows are life-long laborers. There is no retirement in sight for them, just work until they die. Put more eloquently by McSorley, "His horizons held no day when the last ladle would be poured into the flask and he would pick up the tools to say the work was done for good and all now" (17). It is no wonder that the Irish in America became so active in the labor movement (Kenny American Irish 188), and that some of them leaned toward radical politics including Socialism. McSorley's novel reflects the real-life conundrum that the Irish in America faced between middle class respectability and radical politics, the former winning out in the early twentieth century (Kenny "Labor" 361). When the Catholic Church in America came out against Socialism, Irish support of it faded quickly (Meagher 246). McSorley, though, has painted Pat as a much more sympathetic character than Larry McDermott, who has already abused Willie and some friends after stealing cigarettes in an earlier scene. Pat dies taking a stand for workers' rights, or even for the right to listen to someone speaking about workers' rights. Larry was there at the time of Pat's beating and may in fact have administered 
it. What was a peaceful protest was turned violent by police out to protect American values. Pat is the intellectual, and Larry the brute. McSorley's stance in writing the event this way is clear. Those opposed to Socialism in the novel are in the wrong. They are protecting a system that abuses workers.

Though Ned is not educated and feels the comprehension of Socialism is beyond him, he feels in his heart that workers should be treated fairly, and that the bullying brutality by the likes of Larry McDermott is wrong. Ned does not want to go against the Church, but he is also for workers' rights. This is why he draws a line between Church and politics. He knows the Catholic hierarchy has not always been on the right side of labor issues. It seems, though, that if Catholic people are truly living out the teachings of Christ, they would be on the side of the poor, too. Then there would be no confusion for Ned; his values are always consistent. It is the institutions that have the authority — the police force, the Church—-that are confusing things. These institutions become defenders of capitalism in the United States, and both McSorley and Doyle Curran depict that as inconsistent with who the Irish were when they arrived. Socialism by the 1940s is a dirty word. It has become a dirty word for the Irish in America precisely because it has been set in opposition to the Church, and yet what it is more accurately in opposition to is capitalism. It is no coincidence that an Irish American, Joseph McCarthy, was coming to power as these novels are being written. He embodies both the bullying and the suspicion of anti-capitalism of a thoroughly assimilated Irishman. Irish-American communalism was hearing its death knell in these post-World War II years, and the authors in this study were worried about a future without it. There was too strong a force against it in American 
capitalism to allow the Socialist element of the Irish-American community to survive, though communalism, according to historians, was the Irish way of life before colonialism.

In Our Own Kind, Ned's youngest son Chris could not be more different from his brother Pat and Ned himself in terms of looking out for the common man. Chris is in danger of losing his Irish ways as he tries to climb to a more respectable status than Ned's poverty, and he certainly would not have dabbled in Pat's radicalism. Chris McDermott is shown throughout the novel to be ashamed of where and how his family lives, and cold to Ned's Irish friends and relatives, including the many poor men Ned helps when they stop by for a handout. Chris longs to marry his higher class girlfriend - herself a school teacher, and the daughter of a saloon keeper - and rise up in the ranks of his American Catholic peers. McSorley, through Chris McDermott's calculated use of the Church to plan his social rise, subtly critiques the Catholic Church he sees becoming a social club. Remarked upon as a good Christian by other characters because of his attendance at Mass and membership in all the right Catholic clubs, Chris is presented by McSorley (and seen by Ned, Willie, and eventually his fiancée Catherine Daly) as lacking generosity for the less fortunate, as well as lacking in warmth and joy. Chris is a new kind of Irish-American, not understood by Ned but put on a pedestal by his mother, who shared his "what would the neighbors think?" attitude: "Chris was her son, her pride and joy that never missed mass on a Sunday or a holy day of obligation, that never did so many things his father did it was a great puzzle and a mystery until the day he died how he spent his life when he was not keeping books in Ryan's ship chandlery, presiding at meetings of the Catholic Club or 
marching in the Holy Name parades" (4). Chris makes a good show of being Catholic, but there is a coldness to his Catholicism. He does not have the natural generosity of Ned, nor his sense of fun, and despite his outward shows of godliness, he does not behave in a truly Christian way. Ned's generosity to all in need is both Irish and Christian. Chris's Christianity is pretense and stuffiness. Even Catherine, notices a “righteous chill to [Chris]...that she was sure Old Mr. McDermott didn't have" (110). Chris is selfish, resisting his family's move to the new neighborhood after Willie's legal trouble because "All his plans were centered within the indefinite confines of the cathedral parish where he had already become known as one of the most promising young men" (113). Chris represents the dangerous strain in Irish-American life observed by McSorley and Doyle Curran, which puts self before community and a cold, sterile Catholicism before sincere Christian charity.

Chris has middle class pretensions, and tries to distance himself from what he finds the less desirable elements of his Irish extended family. Upon being embarrassed by a story about a distant cousin in front of Catherine, Chris explains, “"You know how those old-fashioned people from Ireland are.... Their talk and their ways are so different. Besides, we hardly ever see her any more. I don't think I'd know her if I met her in the street"' (51). Chris would like to distance himself from this cousin, and all kin like her. He wants nothing to do with what he considers oldfashioned and backwards — nothing that will remind him of the low rung upon which his family started up the ladder of American success. What Willie observes in his Uncle Chris, however, is someone who is miserable for all of his accomplishments. Willie interacts with other men who stop to play baseball with him and his friends. 
Though these men are hard laborers and often drinking, they are kind to the boys. These men have no social pretensions. Willie compares them to Chris: "About the same age as his uncle, they were freer and happier than he was" (146). Chris has begun the journey of self-loathing that can accompany a rise out of one's community.

Chris McDermott is not alone in representing this social climbing type in Our Own Kind. Ned criticizes Pete Carron, his wife's cousin who, when new to the United States with nothing of his own, stayed in Ned's attic. Pete rises to be head of a bank not through honest means, but by loaning money to people in unfortunate circumstances, such as the newly widowed who need to pay their bills. Pete always seems to be there to offer a hand, but he is also there to collect—with interest—even from those who find it impossible to pay. That he does this to his own people makes Ned furious, but it shows an example of one way the Irish rose, by emulating the ways of free market capitalism. Ned has mixed feelings about Pete's success: "Pete Carron never did a dishonest thing in his life—without a profit. He wasn't one you'd be proud of among yourselves, but a damn good thing to let the Yankees know they weren't the only ones in the banks these days" (18). Pete's behavior would normally have been shameful in the Irish-American community but Ned and other Irish Americans realized they were on hostile ground in the Yankee-run business world. One of Willie's other mentors, Father Joe McCaffrey, explains to Willie why some Irish Catholics say young Irish Americans should be educated in the public schools when others are so insistent on parochial school education to safeguard Catholic values. Father McCaffrey says, "Some contended...that a Catholic, facing a hostile world of business and politics and religion, ought to educate himself among these very 
people, providing, of course, his faith was strong enough to withstand it" (173). Both McSorley and Doyle Curran show that it was very difficult, not only for individuals but also for Irish Catholics as a whole, to withstand the influence of American Protestantism and capitalism despite their best efforts and fiercest denials.

That the immigrant generation is dying out and leaving their American grandchildren without direct ties to Ireland to ground them is of concern to both McSorley and Doyle Curran. Ned, who significantly is an iron moulder, sees it as his duty to mold Willie into a man who will command respect for his knowledge, but also be compassionate to those who may not have risen as high. He does not want Willie to forget from whence he came, from humble beginnings and, generations back, from Ireland. On his deathbed, Ned uses his iron casting as a metaphor for the work he had left to do in molding Willie: "God help me the job is only half done, only started. It's only the pattern is put into the flask and the sand pounded around it, the iron's not poured into it.... I'm standing... with the empty ladle in my hands, the job only half done" (274). Ned is only part way to molding Willie into a gentleman scholar when he dies. Ned's plans for Willie's future are in doubt when Willie's uncle Chris, the man of the house after Ned's passing, suggests that Willie must find a job to help with the finances instead of continuing his education. Willie is only about fourteen at this time. Once Ned is gone, all his careful plans are gone with him. The immigrant generation cannot stay to guide young Irish Americans through the molding process that would make them successful Americans while maintaining a positive connection to Irish roots. Though Willie despises his uncle, who has always been jealous of Ned's relationship with him, he also realizes the stranger Ned's plans for his future 
would have made of him (304). Wise as Ned is, even he does not see that as the potential end result of his hopes and dreams. Only Willie suspects that in being educated up and out of his community, he will no longer recognize himself.

McSorley, writing 30 years into the Irish American future, sees the strangers who have been made of the very opportunities their immigrant grandparents dreamed for them.

After Ned's death, Willie ponders how long the family will leave Ned's hat on the nail where it always hung on the kitchen door when he came in. His uncle Chris will not remove it, Willie decides. Chris wants to take over as the man of the house, but he knows he cannot replace Ned in the hearts of the rest of the family. Chris is the second generation Irish ready to emerge when the immigrants are gone. He is ready to have their memory of poverty wiped clean, in favor of the middle class respectability he so desires. The other immigrants, Willie's grandmother and her sister Nora, have too much love for Ned to remove his hat from its nail, Willie thinks. Willie recognizes at the end of the novel that the immigrant generation is dying out:

The hat might be there a long long time, as long as his grandmother and Nora were there. But that itself might not be so long, either. Soon, Willie thought, all these old people would be laying out there under the willows at St. Ann's where his grandfather lay... leaving behind what? A little shell of a house someone would snatch from those dear to them, probably, an old hat, a pair of silver rosary beads and the memory of a few bright words in the hearts of those they left behind. (303)

Ned's hat is the prosthetic for memory in this scene. It represents all Ned was to the family. It is a memory aid the family will not dare remove, but when the people he leaves behind die out, the hat will go, too. His "few bright words" will be lost with them as well. This penultimate scene, followed closely by the final paragraph where Willie realizes that his grandfather would have educated him into a scholarly stranger 
to himself and his community, evidence McSorley's need to re-member Ned's generation. When McSorley is writing they are already in the past. The author knows how few of their words and values have survived, because he is living in a time beyond them, when the Chris McDermotts and Larry McDermotts, social climbers and bullies, have become the face of the Irish-American community.

\section{A community is deformed by American values in The Parish and The Hill.}

The Parish and The Hill is a book about communal memory. The central conflict in Doyle Curran's novel is the battle between retaining one's Irish self and losing it as one tries to move up in American society. Chapter 1 introduces its two opposing settings, Irish Parish and Money Hole Hill. These two settings have personalities as if they were human characters, with Irish Parish acting as humble immigrant protagonist, and "The Hill" the stuck up native antagonist. This conflict is evident even in the title, as "the Parish" is Irish Parish with its concentration of "shanty Irish" Kerry immigrants and their families, and "the Hill" is "Money Mole Hill," the residence of the snobbish lace-curtain Irish and the Yankees they so desire to be like. The authentic Irish, in Doyle Curran's view, stay in the Parish, while the social climbers move, appropriately, up to the Hill. The book moves chronologically from the original Irish immigrant community in the Parish, to the youngest generation who are mostly third generation Americans, and whose families are starting to make the climb up the Hill. Narrator Mary O'Connor's family has moved to "the Hill" at the insistence of her father, who looks up to the Yankee members of the community as models of respectability. Mame, Mary's mother, agrees to the move only because she 
honors her wedding vows. She mourns the loss of her Irish community. The rest of the story recounts the tensions between the characters who desire to be Yankee (though they are never allowed to be) and those who want to retain a sense of Irishness. That Irishness gets diluted as the generations go on, with few exceptions. Johnny O'Sullivan, narrator Mary O'Connor's immigrant grandfather, remembers how good things were in Irish Parish when he first arrived, presumably in the late 1800s:

There was no dissension then. We were all the same, and if a woman made a cup of tea there would always be a friend by to drink.... There was always plenty. You will never see those days again, for they are gone, all of them, and it's the Hill that did it, the Hill with its pot of gold and Irishman fighting Irishman to get at it. Irish Parish was full of peace till the time came when the serpent got into the garden and none content after - all of them making the gold rush to the Hill and trying to outdo the Yankees at their own game. (49)

It was hard to resist the temptation of the capitalist serpent, once it entered the Eden of Irish Parish. This same serpent, with its dual fangs of wealth and respectability, made any who did not live up to its new way of life feel inferior. Mary explains, "I grew up on the Hill, with my grandfather and then my mother protecting me as well as they could against the misery and shame of being shanty Irish on Money Mole Hill. All of us, for the first time, were introduced to an insecurity and isolation that has not lessened during the years" (95-96). This move from Irish Parish is shown to be more traumatic for these characters than the original move from Ireland, because this move is what finally breaks the sense of Irish community they had managed to retain when concentrated in the Parish, sharing the same culture they had shared in Ireland. Mary O'Connor is the voice of the third-generation Irish American, pulled between her grandfather's Irish traditions and her father's and brothers' desires to be American. 
"I remember when I was born," Mary says to start Chapter 2. It is not her literal birth she remembers here, however, but her birth into consciousness of the community she shared with her grandfather Johnny O'Sullivan. He is her earliest memory. He is also her only living tie to Ireland. An immigrant from County Kerry, Johnny is acknowledged as the greatest storyteller in Irish Parish. Mary says, "His stories were always a curious mixture of religious, political and social thought" (37). Johnny's apartment in Irish Parish, like Ned McDermott's in Providence, is the gathering place of the neighbors. They come to sit by the fire and hear his stories after long days of work. Johnny is also a leader, and someone the other immigrants turn to for political advice. When others express a fear about "foreigners" (the newer Polish immigrants) coming to take Irish-American jobs because they are willing to work for less, Johnny responds, drawing parallels to English colonialism in Ireland, "it will do no good to be fighting with them. It's what the Yankees may be looking for. They're great dividers of the opposition, as you well know, setting one half of a country against another. You've all seen the waste in that" (27). As is Ned McDermott, Johnny is keen on keeping workers united, no matter what their ethnicity, against the bosses who would abuse them. When his friend complains that the Poles "don't even speak English" and are "jabbering away in a foreign tongue with no one to understand them but themselves," Johnny responds with anger, "And since when is it that an Irishman takes a pride in the English tongue?” (27). Unlike McSorley's novel, Doyle Curran's features a native Irish speaker who recognizes that English should be held as no prized possession for the Irish. Johnny sees the Irish as equally foreign and therefore natural allies with other immigrants, if they all want the rights they deserve. 
This is a sense the Irish were losing as they assimilated into mainstream America. Johnny similarly vanquishes a campaign manager for a young political candidate, who tells Johnny that his candidate will improve conditions for the Irish by getting rid of the Poles who are after their jobs. Johnny refuses to back the candidate and is labelled as crazy, but his wisdom is clear to the reader (29-31). Johnny understands and fears the way Irish Americans are headed if they rise by stepping on other people's backs. Johnny's eldest daughter Mame, Mary’s mother, inherits his compassion for those with less than them, which makes her a fierce Democrat in this country, until the Democratic party starts to turn against newer immigrants to her dismay (77). Johnny’s and Mame's qualities, in Doyle Curran's book, are portrayed as elements of an authentic Irishness. Mame laments the move to the Hill at her husband's insistence. This ill-chosen marriage disrupts Mame's ability to stay with her community and experience her culture: "My mother was unhappy because all the gaiety had vanished from her life. There were no stories, no people dropping in at every hour of the day. The strange, saturnine man she had married did not encourage either people or stories. He had no sympathy for either the Irish people or their imagination" (95). The move is traumatic for Mame because she no longer has a shared cultural memory with those in her immediate neighborhood. She finds she has more in common with the poorer people of English descent on the Hill than with the social climbing lace-curtain Irish, who are trying so hard to deny from whence they came. Mary describes the trauma Mame endured over losing her people to American values including ethnocentrism and the scramble for material wealth: "More and more, my mother grew ashamed of her race. She was puzzled and painfully distressed because, deep down in her soul, 
she did not understand what was happening to her people; and though she lashed out at them, her alienation from them made her sorrowful" (77).

If this novel is a bildungsroman of the Irish-American community, the birth and early childhood are represented in the immigrant generation. This is the generation who knew Ireland enough to both love her and leave her. Though their home is missed, it is missed with the knowledge that all the beautiful views could not feed them, and the beloved friends and relations left behind were no better able to put bread on their tables. If there is a nostalgia for Ireland, there is a pragmatism, too. Johnny O’Sullivan explains what young Willie McDermott could only wonder at when his grandfather and friends remembered Ireland, the land where they were hungry and out of work, so fondly. He recalls, "It was with great sadness that I left a country which could give a lad the joy of all its own liveness. I remember getting on the boat and thinking, now I'll maybe never come back and perhaps it's here I'm leaving the best of me." After a sigh, he admits the advantages of settling in his new home:

'It was good in the Parish when I first came, more like the old country than Boston just a hundred and fifty miles away....The Parish itself had nothing of the look of Kerry, but the people were the same.... There was the same gay look in the eyes of these people and there was love among them. None of us who were used to the fresh shining air of the sea and the green grass of Kerry liked the dark mill, but there it was and a man could earn a living for himself and his family in it. It was better than the old country for all that, where a man could watch his children starve and he not able to bring them a bite.' (48-49)

Johnny is a character drawn so clearly, and with such compassion, that it is easy to forget while reading that he is a fictional creation of Mary Doyle Curran. She has imagined the ideal Irish immigrant to found her Irish-American family. Johnny 
O'Sullivan represents the gold standard of Irish values that should have been passed down in a perfect world of uninterrupted cultural transmission.

Not only does Johnny remember Ireland, but he also remembers his language. $\mathrm{He}$ is a native Irish speaker, who speaks the language with his wife until the day she dies. He speaks in English to his American-born children. When young Mary becomes his closest companion, however, Johnny is suffering from dementia, and he speaks his language again. Mary remembers:

I walked beside him, holding his hand, while he talked, talked in a language I have never heard since. His voice was beautiful, and as impossible of reproduction as pure music. The intonations were those of the purest Gaelic speech. The whole talk would be a long monologue, for he talked as though he were conversing with the disembodied, and indeed he was. Everything came to life as he spoke. In the world he created for me, the man in the moon was as real as the man in the street. (21)

Mary understood his Irish with the ease of a child. That she has never heard it since is evidence of the disrupted transmission of this crucial vehicle of culture, the native language. Johnny's disembodied voices with whom he communicates are his dead. They are the only people who speak his language. Mary seems to understand it, but never speaks it. When Johnny is gone, the language for Mary is gone with him. The ties to those disembodied voices are severed, and no longer can Mary commune with her dead in their language. The same goes for most of the Irish-American community.

Johnny was separated not just by language from the younger generation of Irish Americans, but by custom, especially in the understanding of a spirit world. When failing health forces him to move away from Irish Parish and in with his daughter Mame's family on the Hill, Johnny loses what was left of his community. This is the break, not the break with Ireland, that ends Johnny's life as he knew it. 
With no community, and thus no shared collective memory, he begins to lose his mind. "It was the Hill that stifled him," Mary says (39). Johnny explains his disconnect:

'What's the use of talking there when no one has the mind to comprehend you? If you meet a man on the street and stop him to tell him that through the window last night you saw a great procession pass and that he was among them, he would think you crazy, but if you tell that to Bridgie Flynn in the Parish, she would wash herself, put on her best, make a visit to the priest, say good-bye to her friends and go home to die. A dog howling on the Hill is only the howl of a dog-in the Parish it is an omen.' (39)

The Parish is a place where, like Johnny's Ireland, the world is still understood as enchanted. On the Hill the same beliefs shared in the Parish are looked at as crazy, backward, or old-fashioned. Johnny represents the Irish past that is fading away. Both his language and his beliefs in the otherworldly among us are not of use to those wanting to rise in middle class America. Worst of all for Johnny, his stories are no longer appreciated by the next generation. He thinks, "How could he tell his stories to his own sons and daughters, who would only hush him for his superstitions?" (39). His social-climbing daughter Josie calls the stories exchanged in Irish Parish "fairy tales", and forbids Johnny from visiting there anymore when he prophesies his own death after he hears the wailing of the dead two times (the third time would be for him) (40). There is no room, in the world the Irish Americans have entered, for enchantment. The Irish like Josie want to be modern, and enchantment and the modern cannot coexist. Those who see themselves as modern want to attribute belief in an enchanted world to an earlier time in their development; they have to relegate it to the past (Chakrabarty 87). In the case of the Irish in America, a belief system such as Johnny's had to be labeled quaint and cute, a thing of the past, but something that 
Irish Americans had outgrown. If someone held those beliefs in the present, as Johnny did, he was deemed feeble-minded. This is a clear break with the dead of the Irish nation, who had always been included in the Irish present rather than seen as in the past. Of the story tellers in Irish Parish, Mary recalls, "In telling the stories, there was always one man or woman who was favored, depending on the number of supernatural visions he or she had had. The one with the longest memory was best, for he could tell visions that were none of his own, but belonged to those dead ones whose names were forgotten" (4-5). Beyond the immigrant generation, the chain that connected the Irish-American community to their dead would be weakened. The visions of the dead would no longer be shared in an America less concerned with the supernatural, and more concerned with future success.

Another element of Irishness in danger of being lost in America according to both Edward McSorley and Mary Doyle Curran is a keen sense of social justice. In separate episodes in The Parish and The Hill, both Johnny and Mame show their compassion for others, non-Irish, who are poor and oppressed, as Ned McDermott does in Our Own Kind. Like Ned, Johnny O'Sullivan has a profound influence on his grandchild, showing her how to treat others with compassion. One day at the park he gently nudges Mary into sharing her candy with poor Polish immigrant children after she has shown off in front of them other weeks. Mary says of the incident, "My grandfather drew no moral for me, but I heard him speaking to my mother that night: 'It's the sense of ownership that divides people. It's happening in the Parish the same way as on the Hill. It's an evil that spreads, you will see. There will soon be no oneness there either"” (25). Ownership is a capitalist and therefore American value; 
sharing is a communal value. While preschool-aged Mary was inclined to be greedy, her grandfather gently guided her to build community instead. In his old age and increasing dementia, Johnny O'Sullivan is the young Mary's closest companion. When he is gone, Mary's sense of Irish community is diminished significantly. She says, "I remember the day my grandfather died; for on that day a world died for me, and I was left walled into my own small spirit, and into an isolation I knew would never pass. The only member of my community had gone, and the world was as empty as the day I was born" (52). The isolation Mary felt without her immigrant grandfather is akin to what the emigrant would feel leaving home, or more fitting for this book, what the Irish American would feel leaving his or her concentrated Irish community for the wider American world.

Thankfully, Mary discovers that her mother can provide a continuity of the warmth and values she found with her grandfather. Mame is a second generation American who has not lost touch with her Irishness. Mame, like Johnny, stands up for the oppressed. Her son Tabby has grown from a cross young boy into a bully, despite Mame's best efforts to change him. When Mame catches young Tabby taunting an old Jewish man outside his home, she marches Tabby inside to apologize. As Tabby grows up he is no better. He goes off to Boston to social climb among the lace curtain Irish, where he bullies and lies his way into favor with some big names in the IrishAmerican community there. One $4^{\text {th }}$ of July Mame takes Mary to visit Tabby in Boston. While Mary and Mame ride the swan boats in the Public Garden, Tabby goes off to have some drinks. He comes back drunk and, as usual, ready to fight. His target this time is an African-American man trying to speak to a crowd about freedom. 
Tabby gets in the man's face and tells him to move on, calling him racial slurs. Mame will not stand for this behavior from her son, grown man or not. Mary remembers:

When Tabby came up to my mother, she looked at him, on fire with anger. 'And who do you think you are to be pushing people around, I want to know?' He said soothingly, 'Oh, Ma, you don't understand these things. We're having a lot of trouble in Boston with Jews and Niggers.' 'And,' my mother said contemptuously, 'exactly who are we?' Tabby looked at her surprised. 'The Irish, of course.' My mother glared at him. 'You and all the rest of them are a great tribute to the Irish, I can tell you that. If I had enough strength in my right arm, I'd lay a clout on you that would knock the bully out of you.' (179)

Tabby is the embodiment of Johnny O'Sullivan's fears. Tabby has lived his life only for himself, never for his family or his community, and always at the expense of those perceived to be on a lower social rung than him. Tabby, who would punch someone who said a word against the Irish, does not see that Mame retains Irish culture in a way that so few in America could. Instead, he says of her, "She's an old witch, with her songs and stories, scaring the daylights out of her kids. Her old man was as bad. Holding their heads in the air without a dime in their pockets" (217). What Tabby and the others fail to see is that Mame and Johnny had a dignity that came not from money, but from living out their values of kindness, generosity, gentleness of spirit, and a strong faith that included looking out for one's neighbor no matter his race or creed. For both Mary Doyle Curran and Edward McSorley, the children and grandchildren of the immigrant generation are in danger of losing these values as they become American.

In The Parish and The Hill, Mary O'Connor's aunts who have chosen to chase lace curtain respectability, or worse, Yankee money, are miserable if not insane in the end. Aunt Josie marries another social climber and moves to the Hill for what she calls social reasons (but what are really business reasons, to make the right contacts 
for her husband Tim's business). Mary says of them, "She and Tim were the imitators of those whom they secretly despised and secretly felt humble before, and the detractors of their own people whom they could openly and safely snub. Insecure before the Yankees, they secured themselves against the shanty Irish with a position that only money can buy" (151). Doyle Curran points to material greed and desire for social status as the reasons these Irish Americans turn their backs on their community. Of Aunt Josie emulating the Yankees, Mary explains, "Both she and her husband picked up their worst traits, their stinginess, their hard-headed business methods, the ways...that made them owners of the mills in Irish Parish and family-proud with nothing but a shopkeeper's ancestry behind it" (150). Doyle Curran's disdain for these and other similar characters is never in doubt. She speaks through Mame, of whom Mary remembers, "Her scorn for the lace-curtain Irish was constant. She used to say, 'Put an Irishman on a spit and you'll find a lace-curtain Irishman to turn him'” (97). This does not stop even the seemingly confident Mame from, for a time, trying to fix herself to Josie's liking when she visits. Mary remembers that "Aunt Josie, always so confident and sure in her own 'style,' as she called it, characterized a hanging slip, a loose hair, a knot in the shoelace, as 'shanty,' and felt that when those lapses were remedied, the transformation from shanty to lace-curtain had begun" (144). This transformation Josie sees as a positive; the goal was to change who you were entirely, in the name of respectability. What Doyle Curran exposes is that in this drive for respectability Irish Americans were losing their souls. They may be proud of the heights they have reached financially and materialistically, but they are otherwise lacking all joy in their lives. Mary explains, "Aunt Josie had worked very hard at 
respectability and achieved it in all its stuffiness" (143). This is not the way Josie and the rest of the O'Sullivans were raised in Irish Parish. Mame reminds Josie of the warmth their father brought to their tenement home as children. Even if they did not have much materially, they had so much more. Mame asks her sister, "Have you left off remembering the past, Josie, that you can so easily dismiss the joy of it?” (44). Doyle Curran might just as well be posing that question to her Irish-American peers in the 1940 s.

Another of Mame's sisters, Aunt Hannah, undergoes the opposite of a Dorian Gray transformation. The portrait her Yankee husband's family has commissioned of her retains her fair-haired beauty, while on the outside she transitions to ugly old hag. She withers up with hatred, bitterness and greed against her husband's family. Here Doyle Curran is the most heavy-handed in her depiction of selling out one's Irishness for Yankee respectability. The Yankee in-laws never see her as anything but Irish, though she is willing to give up everything she knows and is to be one of them. As Mary describes, "Her husband, out of deference to his mother, had seen to it that she received the proper education for a lady. She was refined and polished into a proper nonentity” (153). Hannah tells Mame, “'God knows...I had no desire to remain Irish, but they saw to it that I could be nothing else"” (153). In a literal embodiment of the disruption of cultural transmission, Hannah's only son is taken from her to be raised by her in-laws, and then sent to boarding school as soon as he is of age. Hannah had not wanted the baby; in fact she had tried unsuccessfully to avoid getting pregnant out of spite for her husband's family since she knew they desperately wanted an heir. Nonetheless she is terribly aggrieved, staying in bed ill for months, when her son dies 
(162). Hannah's desire to social climb into a prominent Yankee family was matched only by her desire for revenge when they would not accept her. By the end of her life, Hannah is a mad old woman who outlives the Yankees, but barricades herself in a chicken coop, wearing her father-in law's trench coat and old boots, with equally mad dogs surrounding her to guard her stacks of money. It is a bitterly won inheritance from the family that would not accept her as anything but Irish. This is Doyle Curran's picture of the Irish in America who would trade anything to get a piece of Yankee prosperity. It is a damning picture.

On Mary's father's side, Doyle Curran paints another scathing picture of the lace-curtain Irish in James O'Connor's Aunt Maggie. Maggie reluctantly takes James in as a child when most of his family dies of typhoid fever in Ireland. She and her husband are already established in Boston at that time, trying to blend in with their Yankee peers. They had changed their name from Cavanaugh to Cavendish to hide who they were. According to Mame, when Aunt Maggie took in James, she felt "her duty...consisted of removing every trace of Irish from his mind and manner. She did it by making him ashamed of his heritage" (90). Aunt Maggie "lived according to what the neighbors thought" (91). In Boston when she and her husband first live there, Catholicism is not a religion for respectable people. To avoid being found out as Catholic they attend Mass out of town secretly. Though when the Irish start to hold power in Boston and it becomes more fashionable to be so, "Aunt Maggie became actively Irish and openly Catholic" (91). She put on her Irishness then like a costume, concluding the entertainment evenings she hosted with '“Erin go bragh,' the only Gaelic she knew" (92). These evenings of entertainment are nothing like the clachán, 
though Aunt Maggie wants to pretend they are representations of true Irish culture. Instead, here we see the beginning of what Doyle Curran sees happening to the Irish in America: it is a cold, stilted replica of the warm-hearted original, including Aunt Maggie's reading "off a financial statement, telling how much more had been taken in than had been spent" (92). Even the entertainment had to be for commercial value and social status, rather than the joy of gathering together. It must have given Doyle Curran much joy writing Aunt Maggie’s end: “One night she lifted her arm to emphasize her last words — she got out the 'Erin,' and dropped dead on the stage" (92). In a wonderfully ironic twist, this same woman who had erased any trace of true Irishness from her nephew died with the word "Erin"-Ireland-on her lips.

In The Parish and The Hill Aunt Hannah is rendered unrecognizable by the greed that overtakes her, and her desire to be someone else. Aunt Maggie becomes a cartoon version of an Irish woman, putting on an evening of "Irish" entertainment that has nothing to do with the way the Irish entertained, after once denying everything in her that was Irish. She, more than anyone, represents the type of Irish that erases her cultural identity only to try to re-member it in a way that would be palatable to her respectable American peers. Both of these women are consumed by a self-loathing rooted in the low status afforded the Irish upon entry into the United States in the late nineteenth and early twentieth centuries. Though they have white skin, they still are seen as fundamentally different than the Protestant business and civic leaders who are in charge. The way these characters think of themselves, and try to model their lives after the "Yankees," is evidence of what Frantz Fanon has termed a "psychoexistential complex." In the process of trying to mimic the dominant group, these characters lose 
sight of who they are. The seeds of their own inferiority are planted in their minds, and once there lead to identity confusion and a pattern of self-destruction.

The lace-curtain Irish and the bully are two Irish-American types Doyle Curran clearly disdains. She writes a more sensitive portrayal of another type, in fact the most famous Irish stereotype — the drunk. Mame's brothers all turn alcoholic, evidence of the trauma they have experienced both as soldiers in World War I, and as Irishmen set adrift in America. That Doyle Curran can see the trauma that triggers the alcoholism gives these men a depth of character that most Irish drunks in literature and movies are lacking when they are just used as comic foils. Mary remembers her Uncle Smiley as "Irish from sole to head, but not as my grandfather had been, secure in being that. He was Irish, right or wrong; and he bore a chip on his shoulder, as big as a log" (127). Smiley (a name dripping with irony) gets drunk, and he wants to fight. He cannot overcome the bitterness he has against the English, or against anyone who would put down the Irish in the United States or abroad. He is ready to fight them all, but takes it out on whoever is sitting next to him at the bar. Mary recalls, "He had the wit and charm of my grandfather, but not his desire for peace and justice" (127). The degeneration of these values can be traced from the immigrant Johnny O'Sullivan, to his son Smiley, to his grandson Tabby, who is the most morally bankrupt — and most financially prosperous — of them all. Smiley is passionate about Irish literature, and recites poems of the great injustices the Irish have suffered. Mary calls her Uncle Smiley "a patriot with no country" and her grandfather, too, says Smiley "should have been a Sinn Feiner in Ireland. There he would have had an outlet for his nationalism" (132). Cut off by his parents' emigration from Ireland, Smiley instead "fights 
windmills, standing on street corners reciting revolutionary ballads, shouting Irish songs in barrooms, smashing heads to prove how strong an Irishman he is" (133). Mame laments this great waste; her bright and talented brother, like her beautiful sister Hannah, has been destroyed by bitterness.

Though Doyle Curran may resort to caricature at times, with the noble Mame and Johnny having the moral high ground over their social climbing relatives, her analysis of the changing Irish Catholic church in America, like her understanding of the trauma and depression behind alcoholism, is both deftly handled and insightful. The Parish and The Hill brings up an interesting distinction between the Catholicism these immigrants brought over from Ireland, which was as rich as Johnny O'Sullivan's Irish Parish living room with storytelling and spirituality, with a much colder, conservative, Protestant-influenced church after decades of living and assimilating in New England. Not only do individual characters lose themselves in assimilating in this novel, but the Irish-American Catholic Church does, too. Catholics in New England are sometimes called the "chosen frozen," and an illustration of how that perception came about can be found in Doyle Curran's novel. According to the author, it did not have to be that way, if people were willing to stay true to who they were. Mame O'Connor is the representative of Irish Catholicism, as opposed to American Catholicism, in The Parish and The Hill. Mame's faith is spiritual, not dogmatic, and never used for social pretense. Mary remembers her "mother's religion was made up mainly of candles and holy water" (78) and that "In every corner and cranny of our house was a candle burning for some intention or soul." Mary says her mother "took seriously anyone's request that she pray for him" (79). Mame's 
Catholicism is enchanted with spirits and beliefs that go further back than Christianity in Irish tradition. It is contrasted in the novel with the put-on Catholicism of her husband's Aunt Maggie, and with her husband's cold religiosity as a result of being raised by Maggie. Mame says Aunt Maggie's Catholicism was "watered down by Protestantism" (91). This is the religion Maggie drills into James:

My father's Catholicism suffered, as well as everything else he believed in, for being touched with lace-curtain refinement. It was tinged, as is almost all lacecurtain Catholicism, with the Protestantism of the Yankees they imitated. Catholicism for my father held none of the joy it did for my mother. It was a grim, respectable business requiring monthly confession and Communion and a get-to-Mass-on-Sunday-or-die-in-a-state-of-mortal-sin attitude. Going to church was the respectable thing to do. (107)

Mary's father, enthralled with Yankee respectability, liked the boring sermons of their church on The Hill. Mame preferred the liveliness of her old priest in Irish Parish. When the church in The Parish was first established, the immigrants who funded its construction sent home to County Kerry for a priest with clear expectations: "They wanted none of these strange American priests who would be on bad terms with the Sidhe. A priest who had no charms against the powers of the 'gentle folk' was of no consequence to them, no matter what titles he might have after his name" (12). Though that was before Mame's time, her religion is still filled with the spirituality of the immigrant generation.

Mame tries to prevent Mary's Catholicism from being ruined by the colder, American version of the Church. Mary remembers the worst part of preparing for her First Communion: "The thought of that first confession terrified me.... I would come home after instruction drooping with my sense of sin. All the joy of my earlier religion was beaten out of me" (83). Here again, Mary's development represents the 
development of the Irish community in America. Mame tries to preserve the joy in the faith for her daughter: "Never you mind, Mary O’Connor, what the priest says. You come home to me when he troubles you with his stories. There is no truth in it. God does not want you sad. He wants to comfort you.... Never you mind the priest. He is only the ear through which God hears you. When you go to confession, you talk to God" (84). Fear, fire, and brimstone have no place in Mame's picture of a merciful, loving God, but her understanding of God is becoming a minority view in Irish America in the first half of the twentieth century.

Organizing labor is another concern for the descendants of Irish immigrants in The Parish and the Hill as it is in Our Own Kind. It is a concern particularly ascribed to the members of the Irish-American community whom the authors see as retaining their Irishness, while those willing to give up their Irishness to get ahead come out against the unions. The Parish and The Hill, too, has a sympathetic radical character. James O'Connor's friend from the mill, the Scotsman Hugh, is a union activist. Hugh is “too damn radical” for James's taste, yet James admires his intelligence (103). Unlike James, Hugh is not afraid to rock the boat in favor of workers' rights. It is Mame who finds herself aligning with Hugh's activism. Mary says, "My mother knew nothing about the economics of labor, but instinctively she took the side against the powers that be and came out strong for unions" (103). Those instincts are not surprising given that Mame lives as Christians are supposed to, with compassion for the poor and dispossessed. When James refuses to join the strike at his mill, an embarrassed Mame marches the picket line in his place. Mame explains, "I will go because there will be someone there to represent this family. There will be none to 
say that the O'Connors do not stand with the people they belong to" (104-05). Union activism and socialism are both communal strategies to uplift the poor and working class, not individually, but as a whole. As community-minded ventures they are quite naturally embraced by the characters seen as authentically Irish in both The Parish and The Hill and Our Own Kind. These characters are kind and generous followers of Christ in the truest sense. Ironically Socialism was seen as a threat to the institutionalized Church, but it was not a threat to Christian values.

The character of Eddie, Mary's brother, shows more than any other how The Parish and The Hill is more allegory for the dissolution of the Irish-American community than realistic fiction. Eddie is a gentle soul; disabled from birth with a bad leg, he turns inward to literature and music. He is a violinist and a poet. When the Depression hits and his father loses his job at the mill, Eddie must go to work. The job he does get is a soul-sucking one at the unemployment office, working with people petitioning for benefits. Eddie is deeply troubled by their tales of misery. It begins to distort his otherwise peaceful personality. It is a hard to believe transformation, happening so quickly, but like many of the others Eddie serves as a type or a symbol rather than a fully developed character. Eddie's chapter, the culminating chapter of the book, is one of the places where Doyle Curran puts her social concerns above aesthetics. This is where she drives her point home. Eddie is used as a cautionary tale of what happens to the Irish poet-artist when sucked into American capitalist bureaucracy. He first turns his anger on the moneyed people on the Hill, those lacecurtain Irish his father so admires, and then against the poor themselves, looking to catch them exaggerating their circumstances for financial gain. Finally he turns on his 
own family, whom he is resentfully supporting. Mame asks him, "am I having to tell my own son that he's acting the part of a jackass? What makes you think a bit of money gives you the right to act the tyrant in this house, filling it with a meanness and cruelty that is driving all the good from it?" (208). Eddie, who has always been patient with his younger sister Mary, lashes out at her as she begs him not to leave the family after this fight with their mother. In a scene where the breakup of the family symbolizes the rupturing of the Irish-American community, Mary recalls,

In tears I could not say all the things I had planned, but could only repeat over and over between my sobs, 'Remember, Eddie, remember!'

As an answer he flung me violently into the corner of the room, mocking me. 'Remember, Eddie, remember! And what have I got to remember but the whole stupid lot of you hanging around my neck since I was seventeen, dragging me down to your own stupid level! Remember, remember! I'll remember all right.' (213)

Mary is begging Eddie to remember what he was, what they were as a family, and by extension as an Irish-American community. Eddie is finding it too painful to remember, when he sees so much suffering and no way out of it. Mary has inherited the Irish spirit of her grandfather and mother, but the rest of the family is splintering away. They have forgotten their faith and their values. Mary thrown into the corner, and Mame weeping and "rocking back and forth in her woe" (213) are left in the wake of Eddie's departure.

At the end of the novel a battle is being waged for the soul of Eddie and the soul of Irish America. Eddie has moved in with his cynical friend, Billy Kirkpatrick. Billy is the intellectual who mocks what the Irish-American community has become: "I could be their jub-jub boy leading the parade on Saint Patrick's Day and a fine golliwog it would be, plastering the shamrock on every barnside in the United States. 
Oh, and they'd follow me, too, from the Parish and the Hill, like they follow any priest or politician that is willing to pipe them over the top of the dam" (212). Billy likes to criticize, but in his smugness he suggests no alternative. It is all a joke to him. He jokes about the visiting Tabby being a disciple of the bigoted radio priest, Father Coughlin, whose popularity was one of the many things making Mame sick over what had become of her community. Billy says derisively of Father Coughlin that he "knows what the Irish need is a leader. He'll lead them a fine dance, and one day they'll all go up in a puff and Eddie here will be fiddling for them" (218). He continues,

With Tabby's fists and Eddie's brains and a keg of whiskey to keep both of you from collapsing, we could go far. But that keg of whiskey would be essential, for neither of you bastards have any guts without it....Look at youtwo of a kind - fine typical Irishmen! God, you disgust me! Get out of here, both of you, braggart and coward, two sides of the same coin. Get out! You remind me too much of myself. (218)

This leads to Billy's confrontation with Tabby who was apt to defend the Irish and the Church he barely believed in with his fists. They both tell Eddie how to live, but neither one can make him feel any less sick over what he has become, an Irish American who has lost his soul. He erupts on both of them, claiming he is not like either of them, and then finally flees home to his violin.

Eddie's return home to open his violin case suggests the possibility of healing and re-membering in the Irish-American community, but Mary's dream to end the novel shows that the fight is far from over. The final words of the novel, "Olagon! Olagon! Olagon!" (221) are the same sounds of keening for the dead heard earlier at a wake Mary attends with Mame. At the time of the wake, Mary says of the sound, "It was the cry of the living clutching, clasping at the departing spirit of the dead, 
begging, beseeching his return. It was the cry of those who knew there would be no coming back" (70). At the end of the novel, in Mary's dream, the departing spirit is of the Irish-American community, and though Eddie has finally remembered as Mary begged him to, many more others have forgotten. The connection with the dead has been severed. This book is a keen for the Irish-American community, Mary's keen. There is no going back to the Parish, no going back to what it was. Perhaps that is why Mame attends all the wakes she does early on—not only is she mourning each individual, but also each piece of the community falling away, and the old ways with them. The dead return to mourn the living in Mary's dream. The dead are raising the keen for their values that have been forgotten by this new generation of Irish Americans, who appear in the dream as "red-faced people, prosperous and fat" (220). They have achieved the material wealth they so wanted in America, but in the process they have given up their souls. They are consumed by protecting their new-found wealth. In Mary's dream they chant, "Don't tread on the tail of me coat! Ha! Ha!" Mary says, “With each 'Ha! Ha!' the red-faced people stamped collectively and raised their glasses high in the air. It was a horrible, unmelodious song, and the spirit behind it was vicious and violent" (220). Like Tabby and Aunts Hannah, Josie, and Maggie, these red-faced people have turned their backs on what once made them Irish to protect the money and power they have gained. They are a grotesque embodiment of selling out. They will celebrate the trappings of Irishness acceptable in America, but they lack substance, and they are ready to fight anyone to retain the position they have gained. "Don't tread on the tail of me coat," they say to those coming up behind them. They do not have the power to fight the Yanks, so they turn themselves into them as 
much as possible, treading on those below and causing self-hatred at what they have become. In the dream, Mary says, "As the din increased the figures of my mother and my grandfather rose and with slow, sad step went down the long, dark hallway. No one noticed their departure. I called to them but they never looked back" (220). Eddie stands in the middle of the room, torn between his departing mother and grandfather, and the red-faced people. Tabby urges Eddie to play a song of celebration, "something Irish.... Make it loud" (220), but instead Eddie plays a soft, sweet lamentation for the dead (221). The dead in turn keen their lamentation for the living to close out this allegory of the fight for the Irish-American soul (221).

\section{Conclusion: Communities in Jeopardy}

Through these two novels, Edward McSorley and Mary Doyle Curran are recording what they remember of the once concentrated Irish-American community that was disappearing - the customs, habits, rituals, food, drink, work, and worship of the people they remember from their childhoods. They are also critiquing where that community had gone wrong - the fake Irish, the Protestantised church, and the bullies taking out the way they had been oppressed on those beneath them. At the same time they are re-membering what they see as a more authentic Irish-American past, with the best values and virtues, and some of the vices, of folks like Ned, Mame, and Johnny. Illiterate, but wise and compassionate, a drinker, but a hard-working man who labors at the iron foundry until his body wears out well into his 70s, McSorley writes Ned as a complex human being rather than a stereotype. Doyle Curran does resort to types. Each character represents a type of Irish American witnessed by her. She shows those 
who are allegedly moving the community upward are actually moving them to be something sick, grotesque, and monstrous. Even worse, they appear to be soulless.

Though not written as researched history, these books are alive with the lived history of the authors, and the communities they knew as children. From the authors' perspectives just after World War II, they could see these communities dispersing and were trying to preserve something that was almost lost, for while the Irish kept coming to American shores, they never did so again into such concentrated neighborhoods in great numbers. Both novels, set a few decades earlier than when they were written, show that people were already starting to move away, to make an effort to blend in, to move up and out of poverty and the mills and factories. The values these authors cherished, of their Irish-American ancestors who fought for the little man, enjoyed a good story, and embraced spirituality, were being washed away in subsequent generations. The growing influence of corporate values as well as Irish-American politicians who used bigotry against other immigrant or racial groups as a stepping stone out of the ghetto is seen in these books as the beginning of the end of communal life. Both books show a gradual loss of what the authors construct as Irishness, and the difficulty of holding onto that in this country built on Protestant Yankee values. Interestingly, the books do not show a concurrent rising in economic status, as the families are at least as destitute at the end as they are at the beginning of the stories. Ned has had to spend his meagre life savings to pay for his son Pat's funeral, and the O'Connors, facing James's layoff during the Depression, have had to move down from the Hill. The Irish in America are shown to be selling their souls and, at least in the first decades of the $20^{\text {th }}$ century, getting nothing in return. 
Both of Our Own Kind and The Parish and The Hill dramatize this situation in a way that reflects their authors' fears for what was becoming of the Irish-American community at the time of writing. These fears are presented in different ways, McSorley's through a more conventional narrative, and Doyle Curran's through representations of different types of Irish Americans. McSorley sees the result of assimilation the educated stranger, one who trades upward mobility for knowing himself as Irish. This is not an uncommon exchange for descendants of immigrants to make in America. Doyle Curran takes a less measured approach, painting assimilated Irish Americans as capable of becoming monstrosities. Their internalized sense of inferiority has turned to self-loathing, a loathing they then turn onto others who are less fortunate. The era of bigoted Father Coughlin railing against different races bleeds into the era of Joseph McCarthy, who proves his American status by punishing anyone who steps out of what he sees as the patriotic (but is in fact capitalist) line. Writing between the times of these two larger than life Irish-American figures, it is no wonder McSorley and Doyle Curran were anxious about what was happening to their communities. These men were just the most famous examples of the trends the authors must have seen in their local politicians, neighbors, and family members. Moving their way up the socioeconomic ladder, many Irish were choosing to look down on those below rather than giving them a hand up. These authors wrote to remember, and to critique, the communities they loved. In doing so they leave readers with important questions about what it means to be Irish in America. 


\section{CHAPTER 2}

\section{"Not One Thing Nor the Other": In-Between Characters in the Fiction of Elizabeth Cullinan}

By the time Elizabeth Cullinan (born 1933) began writing fiction in New York City in the 1960s, Irish Americans were just beginning to come out of a century-long cultural amnesia around the event that brought most of their ancestors to America, the Great Famine of 1846-1852. Historians remark on the Famine as the defining moment of Irish and Irish-American history, and yet as Mary Kelly shows, no memorial programs marked its centenary in the 1940s. There was shame attached to Famine memory, shame over the condition in which the ancestors of Irish Americans trying to move into the middle class arrived in the United States. Cullinan's Irish-American characters live in a time when Irishness, long seen as a shameful mark of poverty and incivility, is now being resuscitated as a positive sign of ethnic difference. What can be remembered of Irishness after so many decades of purposefully forgetting it is at the core of Cullinan's fiction. Her characters' Catholicism sets them apart from the rest of the white-collar world in which they operate as New York City professionals. ${ }^{2}$ Their attitudes toward money, toward family, toward faith, all bear the weight of both their Irish and their American values. Cullinan's writing is double writing. Her characters are in perpetual liminal space — on the threshold of being American, of

\footnotetext{
${ }^{2}$ In 1950 , only 9.5 percent of second generation Irish worked in professional fields in the United States, with clergy a prominent part of that number. That same year, only 11.6 percent of second generation Irish were in management, with that number including building superintendents (Kenny American Irish 227). The second generation Irish in 1950 were beginning to move into white collar positions, but "at a slower rate than most other immigrant groups" (Kenny 228). These figures represent the working world Cullinan would soon enter as a third generation Irish American, and for the most part they represent men.
} 
being white collar professionals, of being middle class - but they have not quite walked through that door, for they are still other-Irish, Catholic, working class, women, even at a time when historians agree that the Irish have been fully accepted in the United States.

Mary Kelly writes that "neither the Famine's negative history nor the history of its remembrance would be permitted to derail Catholic Irish economic, political, and cultural progress in the United States" by the twentieth century (Ireland's Great Famine 79). In addition to economic progress, where Catholicism had once been considered a religion antithetical to democracy and American patriotism because of its allegiance to the Pope, Joseph McCarthy's anti-communist campaign in the midtwentieth century helped to align it with strong American values (Kelly Ireland's Great Famine 102-03; Kenny American Irish 235). To start the 1960s, John F. Kennedy was elected the first Irish-Catholic President of the United States, a feat Kelly calls, "a capstone of ethnic acceptance" (Ireland's Great Famine 115). Kevin Kenny remarks that the election of JFK is when the Irish in America "finally became 'white,' if by that term one means full racial and cultural respectability" (American Irish 246). As Kelly notes, however, by the end of the decade that started with JFK's election, the term "white" begins to take on "pejorative associations" as the Civil Rights movement and multiculturalism redefine the country. In other words, it is just as the Irish are comfortable in their place as Americans that they begin to look for a way to distinguish themselves from the rest of the white crowd. This is when Cullinan comes on the scene. Though Noel Ignatiev and David Roediger argue that whiteness 
allowed Irish Americans to move up the American socioeconomic ladder, this movement required an erasure of marks of ethnicity once tied to group identity.

The duality of being ethnic Americans in Cullinan's work is symbolized by the often contentious relationships between the fathers and mothers of her protagonists. Mothers are children's first tutors of cultural identity. Rather than passing down an Irish heritage, Cullinan's mothers find the way to respectability is to distance themselves from Irish poverty and establish their families in the American middle class. It is the fathers in Cullinan's work who exhibit traits that she identifies as being Irish. Some of these are negative traits, such as drinking and gambling, while others are positive, such as warmth, love, and a sense of fun. The mothers, over and over, are the ones who take care of the finances and, importantly, make sure that their daughters are presentable. The fathers give the daughters in Cullinan's fiction Irish last names and freckles; the mothers give them perfumes and advice on how to wear their hair. Being raised by fathers and mothers who are so different in their values gives these protagonists a double vision, and often confusion over which is the better path to happiness, the carefree path of their fathers, or the practical path of their mothers. Irish-American mothers in Cullinan's work do not want to be associated with anything lower class. They want their daughters to look and even smell appropriately. Their insistence on keeping up a higher class appearance shows all the desperation of someone who just ascended out of the ghetto to not be associated with it. Kathleen McInerney aptly labels this attitude "maternal tyranny born of immigrant anxiety" (98). The shame of their poverty is in the too recent past for these mothers. Ann Clarke in Cullinan's final novel A Change of Scene (1982) states this most directly; 
she says, "My Irish name brought me no great treasury of Gaelic custom and Celtic lore. My mother looked down on that sort of thing" (12). Cullinan herself echoes the same sentiment, telling an interviewer, "'Mother hated the Irish. We were supposed to be above all that"' (qtd. in McInerney 99). Historian Peter Quinn explains how this phenomenon worked in his own family, writing that his mother "did her best to scour our family's history so that what was passed down to the next generation was suitable for children of the middle — and one day, with any luck, upper-class" (75). The mothers in Cullinan's fiction operate with this same hope. That earns them the resentment of their daughters who are Cullinan's protagonists. Discussing Cullinan's first novel House of Gold (1970), Eileen Kennedy says, "the reader feels intensely the suffocating atmosphere and resents the manipulations of Mother, who has used the authoritarianism and emotional power of the church to strengthen her control" (96). While this control is over all Mrs. Devlin's grown children, male and female, daughter Elizabeth is arguably the character who has given up most in her life to tend to her aging mother. Elizabeth's daughter Winnie, a teenager in this story, is the closest character to Cullinan's own voice (Fanning 372). Hers is a voice that challenges accepted social class status as well as the hold her grandmother has over her mother. Though Winnie seems to be a minor character compared to the children of Mrs. Devlin who are all gathered in the matriarch's house on her dying day, Maureen Murphy argues, "It is Winnie Carroll's understanding that people have the right to be themselves, to their own identity, that is at the heart of House of Gold, for it urges the claims of the individual over the twin bonds of faith and family in Irish-American life" (147-148). Second generation American Elizabeth is not able to claim her own 
identity separate from her domineering mother. It is up to Winnie, third generation as is Cullinan herself, to break free of the old bonds.

In writing the mother-daughter relationship of Elizabeth and Mrs. Devlin and other characters in her fiction this contentious way, Cullinan is consistent with the “matrophobia" Adrienne Rich identifies as "a predominant preoccupation of feminist women.” According to Rich, “"Thousands of daughters see their mothers as having taught a compromise and self-hatred they are struggling to win free of, the one through whom the restrictions and degradations of a female existence were perforce transmitted" (qtd. in Hirsch Mother/Daughter 136). In Cullinan's work, the "degradations of a female existence" are also bound up in their ethnicity, religion, and social class. The self-hatred comes not just from gender, but from any reminders of being lower class, which in turn are connected to the legacy of discrimination faced by Irish Catholics when they entered this country. It is difficult to disentangle all of these forces at work on the protagonists as they try to figure out their positions in the world.

Marianne Hirsch explains that in psychoanalysis and psychoanalytic feminism, "a continued allegiance to the mother appears as regressive and potentially lethal; it must be transcended. Maturity can be reached only through an alignment with the paternal, by means of an angry and hostile break from the mother" (168). For Cullinan's characters, however, the paternal is also not a satisfactory model with which to align. Cullinan's father figures are infantilized. They are playmates, not masculine models of efficiency and security. These fathers are often rehashes of old stereotypes - the lovable, yet incapable of self-control Irishman. They cannot control their money or their addictions. Cullinan's young women protagonists do not model 
themselves after these fathers. In fact they worry about the traits they have inherited from them. They also do not want to be housewives obsessed with social propriety like their mothers. Instead, they attach themselves to male role models in the professional world they are trying to enter, presumably because they find few, if any, female models there. In many of Cullinan's stories older, white-collar professional men become mentors to these young women. Even these mentors prove insufficient, however, as sexual relationships with the protagonists complicate their paternalistic teaching. To find themselves, ultimately, Cullinan's young women must break from their mothers, their fathers, and these male professional role models. Consistent with the mother/daughter plot Hirsch identifies in feminist fiction, these women must eventually give birth to themselves to determine their own course (166).

\section{Repetition and Working Through Double Identities}

Cullinan engages in a repetition and working through of her own experiences over the course of two decades of writing fiction. Characters, their relationships, and plotlines appear in her short stories and then reappear, with some adjustments, in her two novels, House of Gold and A Change of Scene. Young, educated, professional women with uptight mothers and fathers who gamble too much recur in Cullinan's fiction. The most frequently reoccurring protagonist in her short stories, and also the lead character of A Change of Scene, is a young woman who works either in the publishing industry (magazines or books), or television. Kathleen McInerney calls this young woman Cullinan's "metacharacter" (114). She is most often from New York, although in one story she is from Boston. She often is living abroad in Ireland 
or has lived abroad, as Cullinan did in her twenties. Most of these young female characters aspire to more challenging professional positions, as editors, for example, and some succeed in getting them over the course of the stories. These are unmarried women, often with sisters who have chosen the more traditional path of marriage and family. The traditional path is what pleases their mothers, because to them it means middle class respectability, but Cullinan's young women protagonists have little desire to follow it. This repetition of characters and plots, rather than indicating a lack of creativity on the part of the author, instead indicates a tension or problem she is trying to work through. Problematic relationships with both mothers and fathers, as well as with emotionally or legally unavailable lovers, are explored and re-explored. In almost every story with a young woman protagonist, her parents' marriage is either strained or broken. There is also a larger problem than these intimate relationships; lurking behind or within these troubles at the personal level is the issue that these characters are ethnic Americans trying to figure out where they fit in. They frequently find that they do not fit in, that they are considered outsiders, or that they are straddling two worlds. Cullinan uses the phrase "not one thing nor the other" and the similarly worded "neither one thing nor the other" to describe characters who have double identities in two of her stories. This phrase captures the identity issues of most of the characters in Cullinan's catalog. It is the dominant trope in Cullinan's fiction, and it is used for all manner of identities: social class, religion, nationality, and gender among them.

Charles Fanning sees what he calls "ethnic doubleness" as a common thread in the writing of Irish-Americans in the late twentieth century. Fanning cites Elizabeth 
Cullinan's story "Commuting" as "a defining piece of the... concept of liberating doubleness" (372). In this story, "Everything that the narrator sees while 'commuting' she sees twice, and thus more clearly—as the Irish girl from the Bronx that she was, and the New Yorker that she is now" (Fanning 375). Clearly for Fanning this liberating aspect of ethnic doubleness is a positive. It allows Cullinan's characters to observe the world from two perspectives. Of Cullinan and other Irish-American writers from the same era, Fanning argues,

Their work tells us... that the doubleness of ethnic consciousness is enriching and clarifying.... and that a refusal to decide between the poles of ethnic community and cosmopolitan individuality can mark the beginning of a fruitful, compound life. The middle, straddling position, having something to compare everything with - therein lies a valuable source of energy and insight. (374)

Cullinan certainly taps into this double consciousness as a main source for her creative writing. In her characters' lives, however, this state of being in between causes as much tension and self-doubt from feeling excluded as it does enrichment. To them the doubleness is a negative, prohibiting them from being fully accepted in either identity. It is not always the liberation Fanning claims it to be. When the unnamed narrator of "Commuting" finally approaches the bus stop for her home in Manhattan, it is with relief over having "escaped" that other, ethnic world she has left, a world of poverty, it has just dawned on her, which her mother disguised (35). If she finds anything liberating, it is leaving her former world, not living between two worlds.

Kathleen McInerney agrees with Fanning's reading of "Commuting," as providing an apt metaphor of ethnic doubleness. Interestingly, however, she leaves out his word "liberating" in the discussion of his take on the story (107). Still, she assigns to this doubleness a positive connotation as Fanning does. She contrasts the 
embracing of being between two worlds in "Commuting" with the ending of $A$ Change of Scene, however, where she finds the main character Ann Clarke instead in a "state of ethnic absence" after living in Ireland for ten months (107). One way of reading Ann, McInerney says, is as "a liminal character on a pilgrimage, hoping to resolve the internal argument as to just who and what she is." McInerney finds that "Ann's attempt to pin down her identity may be defined as a journey not toward hybridity but toward indeterminacy and absence: not belonging and not anything" (105). At the end of this, Cullinan's last novel, Ann as "metacharacter," per McInerney, "is older, but she is even less certain of self—more liminal—than the rebellious adolescent [Winnie Carroll from House of Gold], and, at times, less able to reject or adopt new definitions of self now inclusive of and beyond family" (114). This reading does not take into account the final scene of A Change of Scene, discussed below, in which Ann defines herself not as Irish or American, necessarily, but as a citizen of New York, a city she confidently claims as her own. It is that city to which she belongs, and the city which belongs to her. Contrary to McInerney's reading of Ann as ambivalent and alienated (114), Ann's final moment is one of confidence in being able to guide her Irish guest - a man who was once her guide to Ireland — around her city. She is also in a position of authority in the television industry. Instead of being someone's secretary, Ann has a secretary, and a sizable office of her own. Ann is not her mother or her father, but her own woman confident in her place in the world. She has chosen a third option, one not presented by either parent and not available to her mother's generation, of becoming a career woman. In doing so she seems at peace with her identity as that novel comes to a close. As McInerney points out the story "Commuting" is published 
after A Change of Scene, but it is not clear if it comes later in the development of the metacharacter than the end of the novel. It could be coterminous, as both characters have escaped the bonds of ethnicity and class they had once felt. It is then not their doubleness that is liberating, but their finding a new role for themselves beyond the two options they had always been offered. A closer look at Cullinan's fiction reveals how her metacharacter reached this point, and what limiting binaries she had to overcome to do so.

\section{Social Class: In between blue and white collar worlds}

Entering Elizabeth Cullinan's fictional world via the title story of her first published collection, The Time of Adam (1971), it is clear the reader is in a wholly different Irish America than that imagined by Edward McSorley and Mary Doyle Curran less than twenty years earlier. Writing just after World War II, McSorley and Doyle Curran set their gaze back to the first three decades of the twentieth century, when most Irish Americans were still concentrated in tight-knit urban communities built up around Catholic parishes. Their male characters were iron foundry and textile mill workers, laborers with little chance of compiling a savings. The work, unless they were laid off, would not be finished until they died. Their female characters worked in the home, presiding over the religious matters of the family and ensuring that their men's wages were enough to feed everyone and pay the rent on their modest apartments. As discussed in Chapter 1, at mid-century, McSorley and Doyle Curran realize that this Irish America of their youth is dissipating; they write in fear of what is being lost as the Irish blend into the American mainstream. "The Time of Adam," a 
short story originally published by Cullinan in the New Yorker in 1960, presents a stark contrast to memories McSorley and Doyle Curran have of their childhoods. The fears expressed in the post-World War II fiction of McSorley and Doyle Curran of the dissipation of the Irish-American community have been realized by the time Cullinan is writing in the 1960s to early 1980s. It seems that the price to pay for moving up was a sense of ethnic community falling apart.

In "The Time of Adam," Cullinan writes of Irish Americans at leisure, summering in a beach community she calls Riverport, a train ride from their homes in New York City. In Riverport the women and children spend their summers at the beach, and the men join them for weekends after working all week. They have enough spare income to at least rent (if not own) these summer cottages, and the women have time to consume magazines that will further instruct them on what they should desire to look and act like as middle class Americans, Vogue and Harper's Bazaar (4). Their cocktails and their summer clothes are stylish and sophisticated. The only hint at lack of refinement comes from the men, who swim too far out in the sea and drink too much. The men also provide the only hint of fun, as the children and the mothers weary of raising children alone all week eagerly await their arrival. Only when the men arrive do the families re-establish a sense of community; the men travel as a pack. The women are isolated in comparison. The network of relationships between the families, many of whom were cousins, "was scarcely noticeable until the fathers came. The mothers, so self-contained during the week, became not really friendly like the fathers but certainly gracious, and as they called to each other from under circles of shade, talking of beach suppers and cocktail parties, it became apparent to the children 
that their own lives were intimately joined" (7-8). It is the men on their weekends in Riverport who restore something like the communal bonds known to Irish and early Irish-American life. The mothers, as in much of Elizabeth Cullinan's fiction, are more responsible, but also colder. They are less fun. Though at leisure, these women do not make time for one another. They are isolated in their refinement.

Nora Barrett, a young professional woman who is the protagonist of "The Perfect Crime," from Cullinan's Yellow Roses collection (1977), thinks of herself and her family as "neither one thing nor the other" in relation to their status in the beach community where they spend their summers. They are not just weekend "invaders," but they do not own a cottage on the island (119). Instead, they rent their cottage every year. This puts them in between the working class which would not be able to afford a summer-long rented vacation home, and the upper class who could afford to buy the vacation home outright. Nora is musing about this as she takes the ferry over from Manhattan to visit her parents, an in-between state in itself, as she is neither one place nor the other. Nora is one of Elizabeth Cullinan's characters who are both stuck between two identities and left outside of them at the same time.

Another one of these in-between social class characters is Father James Fox, a Jesuit priest at the center of "The Ablutions" from The Time of Adam collection. Father Fox has long been aware of the poverty in which he was raised. In fact, he resents it, and his mother's recent death means he does not have to reenter that world as often. He is happy for the separation: "the truth was he hated that other household. The thought of them all — his sister and her husband and her two sons and, until a week ago, his mother, the matriarch - the remembrance of the old house devastated 
him, driving away, as it always did, the peace and self-respect that twenty years of separateness had built in him" (103). This peace and self-respect has come not only from his belonging to the Society of Jesus, but more specifically for the entry into the upper class that this order has afforded him. He had been headmaster of "some of the Society's expensive preparatory schools" (102), leading him, ultimately, to the role he calls "diplomat" (101), but which is essentially a fund raiser: "It was men of his sort, in the line of princely Ignatius, who inspired wealthy ladies, richly repentant bankers-all manner of affluent people, dying in wisdom, or loneliness, or disillusion - to leave their fortunes to the Society" (102). A talent for this work finds Father Fox frequently in the homes of more of Cullinan's repeated characters, those who attach social status to friendship with the clergy.

In the case of Father Fox, the social climbing nature of these relationships is reciprocal, for not only does it lend his hosts status to befriend the clergy, but it lends him an air of wealth when he is entertained by the wealthy. At the beginning of "The Ablutions," Father Fox feels he can fully enter this upper class world now that his mother has passed away: "His mother had been the bond between him and the world he was born into, and now he was about to cross over once and for all into another world, one that had already recognized him as its own. Death, thought Father Fox, was indeed a door" (102). To this point he had been commuting between these two worlds, straddling the line between the social class into which he was born and the one he desired to enter, through donors who had become friends. Now he thinks he can pass through that door into the world of the rich. From the moment he enters his rich friends' door, however, Father Fox is out of his element. He feels judged by Marcus 
Conroy, who is not Catholic and does not drink. Father Fox does not enjoy the cold meal that Isabel Conroy serves them because her cook has the day off. Mrs. Conroy is of a class where she had not needed to learn to cook. Father Fox is literally uncomfortable in the stiff furniture, and more figuratively in the "tendency among the rich to dispense with many of the social observances" (107). After welcoming his mother's death as his door to this world of wealth, he finds himself comparing the habits of the wealthy negatively with those of his mother. When he sees Marcus Conroy carrying two drink glasses in his hands, he thinks, "In the old house where he had grown up, trays were always used for service and the simplest refreshment was offered with its accompanying napkin, whose lace borders his own mother had worked" (107). Father Fox's family may not have had much, but what they had was earned by hard-working hands, and displayed with pride. Father Fox again compares Mrs. Conroy negatively to the people he would have known growing up when he looks at her and sees "that face which, however experienced, seemed to have had no experience of those twin travelers knowledge and pain" (110). Mrs. Conroy is shallow, callous to any grief Father Fox may have over his recently deceased mother; she dismisses his pain with a quick, "Well, then, we must be very bright and cheerful now, mustn't we, since it's all over and we have you here with us" (107), as if burying one's mother puts an end to the emotions that accompany it. Among the wealthy he had so wanted to join, he is missing a depth of character to which he had been accustomed growing up among people who had not had life so easy.

Father Fox is finally awakened to the position he has among the wealthy when he finds that the Conroys' recently engaged son, whom he managed to keep out of 
most trouble during preparatory school, would have a different clergyman, of even higher status, preside over his wedding. It seems that Dickie Conroy is marrying even further up; his fiancée has "a Bishop up her sleeve," who is a family friend, much to the delight of Mrs. Conroy (113). Father Fox is asked to assist on the altar, a request that is an unintentional insult and a final reminder of where he belongs and where he does not. He thinks, "What place had a priest on the altar unless he was officiating? What place, indeed, had he in this room?" (114). This insult precedes an argument in which Isabel Conroy says that the Mass is just drama rather than the sacrifice that Father Fox insists it is. Even with this professed Catholic, a Catholic he now realizes is in it only for the pageantry, Father Fox finds himself at odds and out of place. He quickly makes an excuse to leave this uncomfortable situation. "The Ablutions" is one example of a typical Cullinan dilemma: the protagonist is on the threshold of a world that will not fully let him in. He sees the door open, but he cannot cross through. He also no longer wants to be of the world he has left. Though that may give him a sort of double vision, having seen both worlds, it also leaves him as "neither one thing nor the other." He is ultimately left out of both.

The drive for middle class respectability, in Cullinan's stories most frequently spearheaded by Irish-American mothers, drove out most other elements that were recognizably Irish. Communal living was replaced by consumerism, the desire to own one's own space, one's own single-family home, with its white picket fence separating it from the neighbors. Mrs. Ganley in "In the Summerhouse" from Yellow Roses, is even concerned with her daughter's appearance as they travel to an asylum to visit Mr. Ganley, who has gambled the family into terrible debt and tried to kill himself. Mrs. 
Ganley expresses her wish that her daughter Angela wore her pink linen dress. Angela has chosen to dress for comfort instead. "“It always helps to look your best,"” Mrs. Ganley remarks. Angela responds, "“For a visit to a mental hospital?"” (42). The remark stings, and Angela regrets it, but she momentarily needed to cut through her mother's pretenses about who they were. Mrs. Ganley had grown up poor, a fact her in-laws never let her forget, and thanks to her husband she is on the verge of being poor again. She laments the loss of their car, and that Angela has had to spend all the money she had saved to travel abroad to keep up with the rent and medical bills. When they get to the asylum Mrs. Ganley admires the grandeur of the old home and its furniture. She thinks back on when she wanted to own her own home:

When she was younger, she'd hoped to have a home of her own — nothing like this, of course, just a comfortable house on a nice street, a little piece of the earth where she could reign supreme. She was a homemaker. She loved the things that belonged to her and she loved looking after them-not that there wasn't plenty to keep you busy in a four-room apartment, but it wasn't the same as your own place. (47)

Mrs. Ganley, having grown up in a large family of ten children, had dreamed the American dream, to have some space she could call her own. She comments derisively about the source of her in-laws' money: “'Mr. Ganley senior was one of those clever Irishmen who made some money in real estate,"” she tells her husband's therapist, explaining that the Ganleys were "Comfortable...but not really well off" (48). When the therapist tries to figure out what caused her husband's trouble, Mrs. Ganley bluntly offers her assessment: “"The trouble with Robert Ganley, Doctor, is always money"' (52). She could well be talking about herself, too, as a lack of material possessions, and a home of her own, seems to have been a major blow for her. There she was on the threshold of middle class; she had even married someone 
with at least a comfortable life, but she could not quite make it through the door. Her husband had gambled away her chances of moving up, but that did not mean she would give up on her daughters breaking through in the next generation.

Near the end of "In the Summerhouse," the reader finally hears from Robert Ganley, as the narration subtly shifts from one third-person limited narrator to another, giving Robert the last words after his daughter and wife have introduced him so negatively:

Money. To him it meant no more than good weather-sometimes you had it, sometimes you didn't. He couldn't understand how for some people, for his wife, money was everything, though she'd have denied that. She thought of herself as a spiritual woman, but her interest in things of the spirit was...purely practical, the interest of someone for whom everything has to be concrete and real. (56)

The concrete, the real, the practical, an obsession with money—-these are Yankee traits according to earlier Irish-American fiction. Things of the spirit are more of interest to the Irish in novels of the mid-twentieth century, as well as in memoirs at the end of the century. The most Irish characters are likeable, warm, generous with the money they do have, and attuned to the spiritual side of the world. The fathers in Cullinan's fiction are the most Irish of her Irish-American characters. This puts them at odds with the world they inhabit, ultimately causing a nervous breakdown for Robert Ganley. The mothers are the ones who have to keep the households running. They have to be the practical ones. They are as consumed with being respectable as they are with having property of their own. Their daughters are taught to marry, "and have a pleasant life and a house full of possessions" ("Estelle," Yellow Roses 3). The daughters are left disappointing their mothers because they do not want this version of the American Dream. 
Louise Gallagher, protagonist of three interconnected stories from Cullinan's Yellow Roses collection (1977) is another character who at least temporarily bumps up against the ceiling of her family's social class. Louise has returned to New York after living abroad in England, a journey she takes when she finds herself in a romantic relationship that is going nowhere, a plot point that also sparks Ann Clarke's departure to Ireland in A Change of Scene. Because Louise and her relationship with her married lover Charlie Davis are developed over three stories, the title story "Yellow Roses," "An Accident," and "A Foregone Conclusion," the reader is better able to get a handle on where she stands as a young professional woman and as an Irish American. Louise finds she cannot overcome all the parts of her identity that put her outside of Charlie's world. Charlie inhabits the professional world confidently as a middle-aged, white, Anglo-Saxon male. Before he is her lover, Charlie, a photographer, takes on a mentoring role for Louise, then a young assistant to a magazine publisher. There is no indication that Louise sought out his help, but acknowledges looking back that Charlie shaped her into "the person she wanted to be and had it in her to be" (67). When she was "that poor twenty-two-year-old girl," he had instructed her on everything from makeup and jewelry ("don't wear [it]") to what to read and what to eat ("try anything"). He helped her become more cosmopolitan, but she admits she "ended up hating herself and her ignorance" (67). One of Charlie's other pieces of advice to Louise is "Think for yourself," while he is essentially telling her what to think. Perhaps what he means is to not think like her family, her neighborhood, her religion. If thinking for herself means thinking like him that would likely have pleased him. Of course twenty-two-year-old Louise does not see that, and 
even the thirty-year-old Louise, now a professional editor in the present time of the story, does not comment on the irony. Louise has to remake herself, with Charlie's help, to fit into the professional publishing world in New York City. She is only allowed inside that world when she changes who she is. What she cannot do, however, is remake herself into a woman whom Charlie could marry. There are some aspects of herself that she cannot polish or educate away.

\section{Religion as marker of ethnic difference}

No matter what level of professional success Louise manners to achieve, she is still Irish, and she is still Catholic. In, "An Accident," Louise recounts to Charlie a story of refusing to ask her English friend to explain what a "fish slice" was when she was living abroad. She says she did not ask because, "It seemed low-class.... Fish will always mean Catholic to me, and I thought that in England Catholic meant Irish, and Irish meant low-class" (83). Charlie responds, “Forget about England....Forget about being Irish. If I can forget you're that, certainly you can"” (83). That is easy for Charlie to say as Louise's lover, but he would not marry her. Ethnicity, class, and religion are divides he cannot or will not bridge for her except in bed. He cannot be with her in any official capacity. It seems he cannot forget her Irishness any more than she can. Back from her time abroad, and now in control of her professional career (she is between jobs but in demand as an editor), Louise is finally coming to terms with this part of her identity she once worried was considered "low-class." She reminds Charlie that she is "Five feet six inches, one hundred and eight pounds... of Irish-American Roman Catholic" (76), while he has Scottish roots and came from 
New England and "had married a girl of Scandinavian descent" (76). These differences had once bothered Louise, but not at the time of this story: "All that had given Louise a feeling of being beyond the pale that it took years to get over; when she did, she discovered she liked being beyond the pale, and she got a kick out of rubbing it in" (76). Teasing Charlie about their differences is a handy defense mechanism for Louise who, in her early twenties, was so hurt by them. She remembers, "What an uneven match they'd been; how hard it was for her to see that and how firmly he'd had to go over their differences" (76-77). Those same differences, now that she is a confident woman of thirty who no longer needs or expects to marry him, Charlie says they can forget.

Louise is another of Cullinan's in-between characters, and in fact she describes herself that way in "Yellow Roses": "She'd also got in the habit of saying, 'I'm in between,' and her answer to 'In between what?' was 'Everything. Jobs, countries'she wasn't long back from a year off in London - 'in between twenty and forty, in between happy and unhappy"' (62-63). She stops short of saying she is in between Irish and American, but that is the reality of many of Cullinan's characters, and all of her protagonists. By the last of the trilogy of Louise Gallagher-Charlie Davis stories, “A Foregone Conclusion," Louise finally ends their long extramarital affair. She does so when Charlie tries to give her his grandmother's ring, at the same time that he is explaining to her he had spent the last few weeks at his wife's side, after she had found a lump in her breast. It is not Louise's Irish heritage so much as her Catholicism that finally puts an end to the relationship. She realizes that anything more than an affair with him was "out of the question since [she] was Catholic" (90). 
Oddly, her beliefs have not prohibited her from having the affair, but she realizes they would prohibit her from legitimizing the relationship through marriage.

Louise is still not sure she is going to end the relationship, because she enjoys Charlie's company, until their differences become clear to her again. He repeats a joke he told his wife about going to a Catholic hospital with meat on her breath on a Friday. When Louise tries to explain to him that not eating meat on Fridays is no longer a rule after Vatican II, it is clear that Charlie just does not understand her, and Louise is slowly realizing he never will. When Charlie questions her on why she still abstains from meat on Fridays, she replies, "“Out of habit, I suppose,"” but then changes her mind and says, “"No, loyalty, really”” (93). Though Louise has rationalized away an adulterous affair, she is still loyal to and finds comfort in her faith. When Charlie calls the religious iconography at the hospital "depressing" (93), Louise again finds herself engaging in what amounts to cross-cultural communication. She finds the "plaster Virgins" and "Bleeding Sacred Hearts" that he mocks to be a comfort, but she lacks the words or the desire to explain this to him, so she changes the subject (93-94). Shortly after this she ends the relationship by slipping his grandmother's ring into his coat pocket. She knows that a ring is supposed to mean the stability and commitment he cannot give to her. It is at once an impulsive move and an inevitable one, the "foregone conclusion" of the title. In Cullinan's world these two people could enjoy one another's company, but they would never truly know one another in a meaningful way. It is fitting that it is Louise's Catholicism that drives the final and lasting wedge between her and Charlie Davis. Her faith, though she is not an active or strong practitioner of it, is one of the last vestiges of her ethnic difference in 
the United States. By the 1960s, Catholicism is one of the only traits still holding together the Irish-American community. There are plenty of Irish Protestants in the U.S., of course, but Catholicism is most frequently associated with those who claim an Irish ethnicity. After moving out of urban enclaves into the suburbs, and moving into the white American mainstream in terms of educational level and career opportunities, third generation Irish Americans and beyond had little left of Irishness to which to lay claim beyond their religion.

Cullinan's House of Gold is her most famous and critically studied novel, but it does not directly address a question of Irish identity; it is more about the family's Catholicism and class. Ethnicity, religion, and class, are so entangled for Cullinan's Irish Americans it is hard to see where one ends and one begins. Respectable, middle class Catholicism, aligned by the 1950s as Samuel Huntington points out with American patriotism (96), is the most visible element that remains of being Irish in America by the time Cullinan is writing. Mrs. Devlin, the elderly mother and grandmother dying in her home as the story takes place, with the family gathering for her last moments, was born poor to Irish parents in England, and then sent to live with a wealthy aunt in New York, who provided her with material but not emotional comfort. Mrs. Devlin, who married at age 17 to get out of her wealthy aunt's house, took pride in the large family she raised, with some regret, but also a "certain satisfaction" that "she had given four of her children to God, two nuns and two priests" (3). Another son became a military officer, a daughter a piano teacher and then wife and mother, and the youngest son, the least successful but as Charles Fanning argues the most emotionally well-adjusted of the bunch, a bartender who 
drinks during and/or after work. Justin Devlin is the only one who does not buy into his mother's "vision of herself as saintly paragon and of her house as a house of gold" (Fanning 338). The gold is literally the place settings the Devlins used to celebrate their fiftieth wedding anniversary, but more figuratively could symbolize the drive for American security felt by the child of the poor who had lost so much. As the nonconformist of the family, Justin is the most free, both of guilt and of the desire for status and respectability that drove his mother. He is the only one who still lives at home, having never quite grown up or reached material success, but according to Fanning he is "the best equipped Devlin for the motherless world the family is about to enter. He has perspective on himself and on Mrs. Devlin's dream.... In addition, he is good-natured, easy-going, and likable — the most human of the Devlins" (341). Though not a father himself yet, Justin has the qualities of the fathers in Cullinan's other fiction, the qualities that make them the most fun and the most Irish. He is likable, and free of the constraints put on him by the drive for middle class respectability. That he is also likely an alcoholic who is not quite grown up of course taps into other traits frequently attributed to the Irish. Cullinan does little to directly address Irishness in this novel, but it is there in the lives of the Devlins, many of whom have succumbed to the capitalist, individualist drive as Mrs. Devlin has, to acquire her property and her gold. Those who have given themselves over to religious life have found the other path to respectability available to the Irish at the time.

A similar short story to House of Gold, "The Voices of the Dead" from Yellow Roses, shows middle class materialism taking over even the protagonists' Catholic faith. Again in this story, an elderly mother and grandmother is visited in her home by 
her family. In this story she is not dying, but she is not well. Mary Nugent can no longer walk to Mass, though the church is just across the street, because of her failing legs. Her son, a priest, has obtained special permission to bring Easter Mass to her in her home. The living members of the family gather for the Mass, while the voices of the dead call to Mrs. Nugent from their photographs on the wall. The Mass is offered in the Nugents' living room, with the television serving as "the substitute altar" (107) - a nice touch of symbolism as popular culture is increasingly becoming the new religion of 1970s America. Mrs. Nugent would like her son to use one of her tablecloths, "that lovely piece Aunt Kitty brought from Belgium," as the altar cloth. She tells him, "it would be nicer than that little bit of a scarf you have there" (107). Father Nugent politely declines, assuring her that his is "the standard altar cloth" and that nothing more elaborate is needed. Father Nugent is about substance, while Mrs. Nugent wants style. As with Father Fox in "The Ablutions," for Father Nugent the Mass is about more than pageantry. Brought into Mrs. Nugent's home, however, the Mass becomes her show. She interrupts her son's sermon to request that her family stay living in a spirit of harmony after she is gone, admonishing them not to bicker over her possessions. She goes on to list what each of them should inherit: the furniture, the silver, the linens, "the good service plates with the gold trim," and the house itself, which will be left to her son Leo who lives there, like Justin Devlin the least conformist of the bunch (111). The profanity of interrupting Easter Mass to discuss material possessions does not faze Mrs. Nugent, nor does her asking her daughter to play a secular song on the piano to close out the service. The spirituality and the profound sacrifice of the Mass have been lost in this setting. Even Mrs. 
Nugent admits that bringing it into her living room has made "the ceremony ordinary" (109). Still, it is a source of pride that "at eighty-five she was a woman accustomed to religious privilege," a privilege she has earned in exchange for giving up three of her children to religious orders (103). Though Irishness, as in House of Gold, is barely mentioned in the story, the Nugents are an Irish-American family through and through, with the tension between spirituality and materialism playing itself out in their crowded living room, which is complete with the piano in the parlor, the ultimate symbol of reaching middle class.

The one place Ann Clark of A Change of Scene does not feel like an outsider in Ireland is in the Catholic Church. Though the Irish language spoken by some of her Irish friends had been lost to Irish Americans, Cullinan's generation inherited a strong faith tradition. Ann's mother was one of the Catholics who used friendships with the clergy as her form of social climbing, prompting Ann to say, "the brand [of Catholicism] I'd been given was all pious misconception," but she still feels comfort in attending weekly Mass. She thinks, "Attending Mass in Ireland was my own kind of certification. Among that crowd I could feel as Catholic, anyway, as the rest" (186). When a priest who pretends to befriend her touches her inappropriately, Ann is less concerned with the physical violation than she is for how it makes her feel at Mass. She says, "I resented having what amounted to a kind of dispossession forced on me-your past may not suit you in every respect but it's irreplaceable, and the Catholic tradition was what I belonged to" (185). She does not want to be pushed to outsider status in church, too. Though not completely unchanged by its transplantation to America, the meaning of "catholic" as universal, inclusive, had 
persisted, allowing Ann to bring that part of her heritage anywhere. At one of her last celebrations of Mass in Ireland, however, she notes how those in the church with her, were all very much the same. Of the Irish people, she comments, "Nothing they said or did could change the fact that they belonged together" (186). For the first time, rather than feeling excluded by this knowledge, she feels something missing in the

Irish. She continues,

Looking around me that morning I had to or finally could admit that this also amounted to something not so desirable - a birthright unexamined makes for a false sense of security. Whereas in America it was hard to sustain the illusion that your particular heritage was unrivaled. Any such state of mind was constantly subjected to the need to accommodate, to accept, to make allowances till eventually you were rubbed smooth. (187)

What Ann finds to be a positive, that rubbing up against other ethnicities smooths out differences, can also be seen as troubling from the perspective of loss of cultural memory. That does not trouble Ann, however. These are among her final thoughts on Ireland, while she is in Ireland, and they prompt her to want to explore other parts of Europe before heading home. "I wasn't limited to Ireland," she realizes. As soon as she finds somewhere in Ireland to fit in, inside the Catholic church, she is free to go home. She decides she prefers the diversity of the rest of the world and of America, specifically New York City, where the rest of the world seems to gather.

\section{The insider/outsider dichotomy of nationality}

In "Maura's Friends" from Cullinan's The Time of Adam collection (originally published as "Nora's Friends" in The New Yorker in 1970), the title character describes one of her friends, Patrick Butler, as "not one thing nor the other" (171). Patrick is described as such because he is from Northern Ireland, so cannot quite be 
considered Irish, according to Maura. The young woman to whom Maura is thus describing Patrick identifies with this description. "Like me," responds Cecilia Bell (171). As an Irish American living in Ireland, Cecilia knows what it is to be both on the outside and the inside, a condition in which so many of Cullinan's characters reside. We never hear Patrick Butler accept this assessment of himself, but Maura's phrase sums up the way she perceives him, and others from the North. He is an Irishman born and raised a subject of the United Kingdom but on Irish soil. That he so desires to be Irish, as we see even more clearly in his alter ego Michael Flynn in $A$ Change of Scene, makes identity more of a dilemma for him than it might for some. Still, the fallout from colonialism here is hard to miss: is Patrick British? He does not identify as such. Is he Irish? The Irish characters from the Republic do not identify him as such. He is stuck in the in between, "not one thing nor the other."

The last three stories in Cullinan's The Time of Adam collection feature young female Irish Americans living abroad in Ireland. As is Father Fox, these young women find that they are in some ways left out of both worlds they try to inhabit. Frances Hayes, protagonist of "A Sunday Like the Others," thinks of a bus conductor she has seen frequently before, "If he remembered her, it was probably because he'd made out that she was a foreigner-something she herself was always forgetting and, one way or another, always being reminded of. Here in Ireland she was American, though back in Boston she was what was known as Irish. Irish-American” (119). Frances once again feels her foreignness when she is rebuffed by a little Irish girl she thought she had befriended on the bus. The girl turns away when Frances tries to say good-bye a second time, by waving to her out the window: "Americans overdid things, 
Frances remembered" (120-21). It is perhaps not surprising that an American in Ireland would be seen as foreign, though to the American who has always considered herself Irish, it would be insulting, even hurtful. More surprising is that she is not quite considered American in the Boston of the 1960s. She is still the ethnic other. That is not necessarily a bad thing, as "ethnicity was "in"” in the late sixties (Gerber and Kraut 321). Being called "Irish" in America in the 1960s should not be a problem. While Frances Hayes does not comment directly on her feelings about being labeled as such in Boston, the way she phrases the contradiction of being Irish in America but American in Ireland shows her confusion. She certainly feels left out as an American in Ireland. Cullinan's fiction, taken as a whole, is a working through of this dilemma.

Cecelia Bell of "Maura's Friends" regrets she is not Irish. She often thinks "If I'd been born here, what would I be?"' (166) and says she would never have gone to America because "“I wouldn't want to do that to my children"” (167). Though she acknowledges that she would have been poor, she does not feel the reasons her ancestors left outweigh the loss of Irishness for herself and her imagined children. She finds the cultural misunderstandings she encounters in Ireland "baffling" (160), as does her counterpart Bernadette Shea in "A Swim," another of the final three stories in The Time of Adam. All three of these stories, "A Sunday Like the Others," "A Swim," and "Maura's Friends," feature protagonists who have made some inroads into Irish society through friends and lovers, but who will never be considered Irish in the Ireland where they are temporarily residing. This in-between state will be considered 
at length in Cullinan's A Change of Scene, in which Ann Clarke finds herself in similar predicaments to Frances, Bernadette, and Cecelia.

At the heart of Cullinan's A Change of Scene, seems to be the question of what, if any one thing, is the "real" Ireland? If taken into context with the rest of Cullinan's fiction, however, the true question the novel asks is what, if anything, can an Irish American claim of Irishness after two or three generations in America? A Change of Scene is the story of Ann Clarke, a composite of so many of Cullinan's other twenty-something female protagonists, and of Cullinan herself. After having her heart broken by a married man, Ann decides to travel abroad. She chooses Ireland not in some quest to discover her roots, as most she encounters there presume, but because it is cheap to live there and the main language spoken is English. She also thought that "living in a chronically Catholic country would automatically sort out my feelings on that whole subject" of faith, something her married lover had made her question (10). Landing in Cork after taking a ship across the Atlantic (a reverse immigration into Cobh, the site of so many Famine-era departures), Ann stays at a hotel recommended by an Irish colleague at her New York City television station job. Neil O'Driscoll also arranges for Ann to meet some of his old friends. Without being in the country with her, Neil becomes the first of many of Ann's male guides to Ireland, all of whom have opinions on the right way to experience the country. The novel is framed at beginning and end with the visit of one of these male guides to her office in New York years after her trip. Of Tomás O’Domhnaill, a native Irish speaker from Donegal who seems to have the best claim to an authentic Irishness of anyone she meets, Ann says, "it was he who plunged me into Irish life as I knew it best" (10). 
Tomás and his friends give Ann a window into a life an American, even an Irish American, does not normally get to see. This is just one of the many ways in which Ann is both an insider and an outsider, making A Change of Scene the perfect capstone to Cullinan's decades-long quest to work through Irish-American identity issues.

When Ann first arrives in Ireland, it is frequently presumed that she is there to seek out her Irish roots. “'Come to look up your kin, Yank?”" asks the waiter in her hotel restaurant (15). It is a safe assumption, given that most Americans he sees are likely there for just that reason. The Irish-American journey "home" will fill published memoirs and private bucket lists for years to come. Ann is different; she thinks, "I had no desire to be strictly speaking among my own" (12). Neither parent had encouraged in her any strong affinity for being Irish, and in fact her mother discouraged it. She tells the waiter, “'I haven't any family in Ireland.... Not that I know of" (15), but within hours, on her first walk around Cork city, she is already feeling the sentimental pull of those who do set off to Ireland to discover something about themselves. "Blood isn't the only kind of kinship," she thinks (15). This pull to have an inside connection hits Ann early and often during the 10 months she lives in Ireland. At the same time, she is equally repulsed and rejected by it, and she is frequently reminded of her outsider status. When Tomás first meets her and hears her last name he asks if she is of Irish descent, to which she replies, "not very" (18). Though she has come to Ireland in part because the people are English speaking, on the first day in the country she turns on the radio and hears a man talking "in a foreign language" (15). At a dinner party the next night, Tomás and his friends use that same language, Irish, to exclude her from a conversation (19). She exhibits her outsider 
status by confusing Tomás's native Donegal with Galway. Yet before she leaves Cork for Dublin, her final destination, she has it in mind that she will study the Irish language, one she barely knew existed a few days earlier, at Trinity.

Speaking the native language of the country would be one way to make herself an insider. Ann later admits, however, that she at first naively saw that language as a commodity she could acquire:

I was perfectly sincere about wanting to study Irish at Trinity-sincere but unrealistic. I saw myself becoming fluent in the language I'd caught scraps of when I was in Cork, I imagined conversations in which I made distinctions or even jokes with Tomás O'Domhnaill and his friends, and I pictured myself bringing back with me to New York the Irish language, a matchless souvenir. (34)

Ann does not herself analyze what has put her on the outside of this language - British colonialism and subsequent emigration by her ancestors—but other characters do express bitterness toward the English. Neil O'Driscoll is offended that she would stay in a hotel that "is full of English gentry on holiday" (11), and her English friend Dinah calls herself "the dread Sassenach" (35). Dinah, who has lived in Ireland since secondary school when her parents moved there, is another double character-both on the inside and the outside. She says, "'I must say, it's never seemed to make the slightest difference to Ireland whether I go or stay."” Their Irish friend Molly replies, “'We Irish...have put up with you English for centuries. I'm afraid we've got in the habit of it" (173). Molly is on the inside as a true Irish Irish person, but like other Irish young women Ann encounters, she speaks longingly of seeing New York. There are not many characters who are fully comfortable in the role they are expected to inhabit, or what other people see them as. The insider/outsider dichotomy is 
continually felt in Cullinan's fiction by those who long to be more Irish, or more American. This is one legacy of entanglement between the Anglo and Irish worlds.

In Dublin, too, Ann initially feels on the outside of Irish life. She is "very much aware of being a stranger in the midst of all this fellowship" that she sees in groups of friends passing by. It is Tomás, who comes to visit Dublin and introduces her to his group of friends, who finally gives Ann a key to the inside. In fact her travels from bar to bar and house party to house party with this group of mostly native Irish speakers provokes envy in another one of Ann's male guides to Ireland, Michael Flynn, who wishes he were on the inside of that group. In A Change of Scene, Michael is the name of the Patrick Butler character from "Maura's Friends," the "not one thing nor the other" Northern Irishman. Michael is a travel writer who has explored the rest of Europe, but nothing in his mind can compare to the grandness of Ireland. Michael is an Irish nationalist, with a pure love of country that does not quite admit him as its own, since he was born on the wrong side of the border. Michael longingly questions Ann about her nights with Tomás and his friends, not out of jealousy for her romantic relationship with Tomás, but because he would love to be as authentically Irish as that group. Out of all the men she meets in Ireland, Michael is the one Ann most wants a lasting relationship with, but she is warned by Oona (the counterpart to Maura of "Maura's Friends") to "go slowly" with him (103). In "Maura's Friends" the reason for this caution is stated directly in Maura's thoughts about Patrick Butler: "When he married it would be a girl who'd give him the birthright he felt cheated out of; he would marry an Irish girl" (The Time of Adam 171). Like Ann/Cecelia, Michael/Patrick is both an outsider and an insider, and 
neither at the same time. When Ann's sister Barbara comes to visit and Ann tells her about her relationship with Michael, Barbara sums up Michael's status with the statement: "“How ironic.... A country full of Irishmen, and you come up with one who isn't exactly"' (145).

During Ann's travels in Ireland, the part of her Irishness that is genetically programmed and cannot be forgotten - her looks - is remarked upon by various Irish people, men, in particular. Tomás's friends debate whether she has a Galway or a Cork face; they settle on Cork, where "brown eyes are commoner" (46). Her name and her looks give her some inside status, as does her knowledge of Ireland in comparison with her sister when she visits; Ann for the first time becomes the guide. Barbara remarks that Ann has "developed an accent" and finds it funny that she uses the word "flat" for her apartment (136). When Barbara fails to see the distinction between Cork and Galway, the now experienced Ann repeats Tomás's friend's condescension when she made a similar mistake. She says, "'You might as well compare Dallas with Boston,"” to which Barbara replies "“You sound like the guidebook"” (140). Ann congratulates herself on showing Barbara, "the heart of Irish life, both present and past" (145). However to do this she had had to seek advice from another of her male guides, her friend Tony, who tells her all the best spots to visit. When Ann says to Tony, "Tell me someplace civilized to go," he replies, "Nothing's civilized here in Ireland....You're here long enough to know that-our civilization's in ruins" (123-24). Ann is an insider in Ireland only to a point; the Irish who have been born and raised there still have a more intimate understanding of their history and 
culture than she does. Where one falls on the insider/outsider dichotomy is a relative, subjective position depending on who is judging.

Ann is continually reminded of her otherness in Ireland. Oona's daughters unwittingly insult her by mocking her Americanisms, laughing at the use of the word "cookie" instead of "biscuit," for example (170). The reminder of her outsider status makes Ann uncomfortable: "I never got used to the idea that I had an accent nor to having this pointed out" (170). Michael Flynn, too, is prone to remind Ann "you don't understand" when discussing matters of Irish culture (112). Even though she is brought part way into the inner circle of Tomás and his friends, "the idea of learning Irish has lost its great appeal thanks to the habit [they] had of using the language as a way to exclude [her]" (68). Ann resents this exclusion but then realizes she is even more annoyed that Tomás, who is happy to drink and sleep with her, has not invited her to join him for Christmas. Michael Flynn ultimately stops calling her, too, and she finally runs into him with another young woman, an Irish woman. A broken heart sent her to Ireland, and a broken heart sends her home. When she stops into the Aer Lingus office to inquire about flights back to New York after seeing Michael with his new insider girlfriend, the clerk mistakes her for Irish:

'Are you emigrating?' he said. I started to laugh as I told him I was an American; then I started crying.... 'You look Irish,' he told me.

I blew my nose and said, 'Do I?'

'A bit anyway,' he said on second thought. 'Maybe around the eyes.' (185)

She had once again almost been let in, only to be reminded that other people who were on the inside were able to judge how much she belonged, or how much she did not. 


\section{Mothers and fathers: gender and Irishness}

Though the young women protagonists in Cullinan's fiction are professionals on the rise, their mothers do not approve of this route to middle class comfort. The daughters are still limited by their gender in their mothers' eyes. For the second generation American mothers, women working for pay may still have the stigma of being lower class. Middle class comfort, to these mothers, means women are free to take care of their own homes. Their husbands, if they present themselves well enough to land good ones, will bring home the money. The mothers want their daughters' future husbands to provide the class mobility, rather than the young women themselves. Respectable middle class women, according to these mothers, look good and keep the house in order. They keep up all of the right appearances. Nora Barrett from "The Perfect Crime" is critiqued by her mother for working too much. Mrs. Barrett does not understand why Nora wants a professional career in television advertising instead of a husband and children. She wants Nora to take some time off from her busy job to rest. As Mrs. Barrett sees Nora descend from the ferry to their summer beach community, she judges her as "very pale and thinner than usual. And she'd done something to her hair, pushed it back some way that wasn't in the least becoming" (123). Nora, seeing Mrs. Barrett's face, knows "how far short of her mother's expectations she was bound to fall" (123-24). This is nothing new in their relationship, but an ongoing battle. Mrs. Barrett wonders if Nora is "a little unbalanced" and whether she should have better nutrition. Her oddness, perhaps, could be cured with vitamins (139). Nora is compared negatively to her sister, who was less of a puzzle to Mrs. Barrett because she had married and had a large family of 
children, as she was expected to do. Nora "love[s] her job," but she knows an understanding of how she thrives on her work is "beyond her mother" (125). As excited as she is about her career, she admits that she even puzzles herself by not wanting what her sister has and what her mother wants for her (131). In all of Cullinan's fiction she does not mention any female professional mentor for these young women. It must be puzzling for someone from Nora's generation to see a future for herself as a career woman with no models of how that looks. They look to their mothers and do not see a life they want. That does not stop the mothers from trying to mold their daughters into the women they want them to be.

Mothers, even well-intentioned ones in Cullinan's stories, would like to control their daughters' bodies: the way they dress, the way they wear their hair, even the way they smell. In "The Sum and Substance," from Yellow Roses, Ellen MacGuire has given up all control of her body as a patient undergoing the removal of an ovarian cyst. While in the hospital for a procedure to which she barely assents, fittingly on her reproductive organs, allowing the male doctor to make all of the decisions for her, she finds herself subjected to one humiliation after another-having to remove her nightgown, to have her genitals shaved for the procedure, to give blood and take pills she did not want. Before the post-surgical pain sapped up her reserve of politeness, she even thanked the various medical workers for the unwanted pre-op procedures. At the height of Ellen's pain, her parents come to visit, with her mother bearing gifts. First is a jar of face cream, to keep her skin moisturized. When Ellen protests that she does not care how she looks, Mrs. MacGuire counters, “You will, dear"” (35). The second gift is talcum powder, the use of which is not elaborated upon in the story, but 
which can be used to eliminate excess moisture, especially in the genital area. The final gift is cologne, “"To cover up the hospital smell,"” per Mrs. MacGuire (36). When her daughter is in post-surgical pain that makes her feel like she could die, Mrs. MacGuire is concerned with her looks, her smell, and her feminine hygiene. Ellen is left to believe that she is nothing more than a body, a body upon which others force their decisions and desires. She is expected to be "agreeable" (35) and "the perfect little patient" as she was as a child (11). It is only when the pain is severe that she can tell her mother "That's enough"” (36), a small act of defiance she regrets once a pain killer sets in (37). Bad skin, bad hygiene, and bad smells are all markers of lower class that Mrs. MacGuire would like to erase from her daughter's body.

Throughout this interaction with Mrs. MacGuire, Ellen's father is the more sympathetic parent, asking her how she really feels (36), and coming to her defense against his wife's beauty products: "I think she looks beautiful"” (35). While the mothers in Cullinan's stories strive for middle class respectability and refinement, right down to control over the natural body, the fathers including Mr. MacGuire can be the pal, the friend, the cheerful one. The mothers' love is shown in concern for the daughters' future, a future that should include marriage and prosperity, and that will do so, the mothers' logic goes, as long as the daughters present themselves well. This love comes with constant correction and critique. The fathers' love is shown in different ways. Angela Ganley from "In the Summerhouse" ponders what her relationship is with her father: "If you could say that love was play, then you could say her father loved his daughters, but Angela didn't think love was play” (41). While people thought they were complimenting her when they said her father was like a 
brother to his girls, she thought "what it proved to be was a deprivation. They'd missed out on whatever it was fathers were supposed to give or at least be able to give" (41). Just what it is she thinks fathers are supposed to give is elaborated upon in other stories, as again these father-daughter relationships repeat throughout Cullinan's work. In "Life After Death," Constance thinks, "My father's spirit is something I love, as I love his sense of language, but common sense is more to the point in fathers, and mine has hardly any" (Yellow Roses 171). Both Constance's and Angela Ganley's fathers fell out of grace with their extended families by "tampering with the books" of businesses owned by their brothers-in-law (171). Fathers are supposed to be reliable, dependable, to provide for their families, but these fathers take away the little security the families have gained. This puts stress on their marriages and their relationships with their daughters, who want to love their playfulness, but need them to be more than playmates.

Interestingly, and perhaps stereotypically, Cullinan also attributes to these fathers the most Irish traits. Cullinan's fathers lend credence to the statement, "the task of understanding what it means to be Irish frequently entails a reconsideration of one's father" (Rogers 13). Ellen MacGuire's father, in addition to the relative warmth he shows compared to her mother, has given Ellen a physical trait of Irishness that is written on her face. She feels, "the intelligence there was obscured thanks to a simple accident of nature, the mass of freckles she'd inherited from her father" (Yellow Roses 14). Angela Ganley worries that she has inherited her father's lack of money sense because she gives up her travel abroad savings so easily to support her family, but then realizes she had no choice with her father institutionalized after a suicide attempt (45). 
As much as the genetic imprint of Ireland on Ellen MacGuire's face, the fiscal irresponsibility of these fathers is attributed to their Irish roots. When Ann Clarke in $A$ Change of Scene first gets to Ireland, she sees the many betting parlors in Cork and wonders if she is seeing "the origins of [her] father's troubles" (15). Louise Gallagher's father is described as having, "the classic Irish pattern of wit and improvidence" (Yellow Roses 80). Though the essentialism of such thinking is troublesome - are all Irish and Irish-American fathers fiscally irresponsible just because Cullinan's might have been or because some are?-looking more deeply into Robert Ganley's reasons for losing money and his wife's reasons for wanting it so badly may actually point to different economic priorities between a communal Irish society and a capitalist American society. It comes down to how important money is to one's happiness and well-being.

\section{Conclusion}

By examining the fathers and mothers in Cullinan's fiction, the reader can begin to understand the complexities of remembering Irishness in a country that, much like the English colonizers the nineteenth-century Irish left, equated Irishness with lower class, uncivilized, and sometimes even subhuman traits. The fathers in Cullinan's fiction, while not announcing their Irishness, instead literally embody it in ways that are always tied to the body: freckles, drinking, roughhousing. Even gambling feeds an addiction. When Cullinan's young women wonder how they are like their fathers, it is the same as wondering what of themselves is Irish. Though this is not always named in Cullinan's stories, it is always operating as a subtext. The 
mothers in Cullinan's fiction have internalized Irish stereotypes, wanting to cleanse themselves and their daughters of all marks of them. They are marks upon the body: messy hair, unwanted smells, unkempt clothing. Though they try to forget what is Irish about themselves, it is clear that in doing so these mothers have remembered the shame that comes from being labeled an undesirable other. They are acting out to prevent a recurrence of that shame, to assure that the next generation will be fully accepted as Americans. They are purveyors of American culture rather than Irish culture, and their daughters are left in between the two. That these daughters always attach themselves to unavailable, often married, men, might equally be a rejection of their fathers' irresponsibility and their mothers' desire for them to settle down into marriage and child rearing. That their parents are often divorced or separated symbolizes the tension between the Irish and American sides of Cullinan's young women protagonists.

What being in Ireland for ten months has taught Ann Clarke to embrace is that she is, in fact, an American. In that time she has come to a more intimate knowledge of Ireland than most Americans ever get, a knowledge she treasures even years later, but she is firmly an American, more specifically a New Yorker, and a confident, educated, professional on the rise at that. She recalls her return to New York in glowing terms: "I'd got used to Dublin's watery light, its modest scale, and when I returned here I kept marveling at how scintillating this city really is. I marvel stillwalking past the Beaux Arts splendors of the east side where I live, crossing the Park at night in a taxi, sitting in my office with its view of Manhattan's shimmering glass towers" (189). When Tomás arrives to New York on business and tracks her down 
years later, he is now on her turf. She corrects his Irish-ism - "fortnight"- and now he is the one on the outside (191). She will be his guide. She is not married and she no longer needs a male guide. She is an adult who no longer needs to worry so much about the opinions or actions of her parents. At the end of the novel Ann is in charge. She has rejected both options of Irishness presented by her parents: her father's gambling and impracticality, and her mother's social climbing through attachment to the clergy. Ann Clarke, a composite of Cullinan's Irish-American women who have traveled abroad, represents a new Irish-American woman for the 1980s. She enjoys sexual freedom, a professional career, her own, genuine attachment to Ireland because she has formed her own memories of it by living there, and a sense of her Catholic faith tradition as a part of her life that comforts her. She answers Tomás's question, “"Will we have a drink somewhere, Ann?"” with a decisive, "“We will”" (192). With those words of a woman now secure in her thirties, in her career, and in her place in the world, Elizabeth Cullinan's final novel comes to an end. While 1960 was a watershed year for Irish acceptance in the United States, 1982 is the time when this Irish-American woman finally feels she is on the inside. At last she is comfortable there. 


\section{CHAPTER 3}

\section{The Exception to the Rule: Michael Patrick MacDonald's Memoirs of South Boston and Dissonance in the Irish-American Narrative}

Michael Patrick MacDonald's two memoirs of growing up in South Boston, or "Southie," as it is known locally, call into question the unity of the Irish-American narrative, reminding readers of just how much that narrative leaves out, and exposing the lack of depth behind American symbols of Irishness. In MacDonald's All Souls (1999) and Easter Rising (2006), the story of Southie is the anti-narrative; it gives the lie to the Irish-American success story by depicting a largely Irish-American neighborhood that never achieved such success. Southie, in the 1960s-1980s, was one of the few concentrated Irish-American communities left in the urban ghetto, arranged in largely the same way nineteenth century Irish lived in the United States. As a concentrated ethnic community, Southie has retained some of the same traits found in much earlier Irish neighborhoods, such as cooperative parenting of children at play, and storytelling as communal entertainment. Southie also retained the poverty of those nineteenth century neighborhoods at least into the 1990s, with "three census tracts with the highest concentration of poor whites in America" and 85 percent of the housing project where MacDonald grew up relying on government assistance (All Souls 3). These statistics are not in keeping with the story Irish America tells itself and the rest of the world. Reading MacDonald's two memoirs against the rags-toriches story of Irish America is an effective way to break its narrative coherence.

The Irish-American narrative is a story of upward mobility, of constant social progress made from the moment impoverished immigrants arrived on American 
shores and fought to find work and a place for their families. J.J. Lee summarizes this story in his introduction to Making the Irish American:

Indeed, a popular version of the Irish story in America casts it as a saga, with refugees from the Great Famine of the 1840s flung on America's shores, clawing their way up against powerful enemies to scale the heights they have since reached in politics, law, media, business, and culture - and this by a people who were so long axiomatically dismissed by those who fancied themselves their 'betters' as incapable of mastering any of the higher arts of life. (Lee and Casey 1)

Through hard work and determination subsequent generations procured better and better education and employment, and eventually established themselves in power positions using politics of the Democratic Party and the increasing strength of the Catholic Church. The progress was not only up, but also out — out of the urban ghettos to which the Irish first came in mass numbers in the middle of the nineteenth century through the end of that century. To make such progress the Irish had to overcome great obstacles. The main thrust of the Irish-American story is that the Irish managed to reach the American Dream of prosperity despite the bigotry they encountered, bigotry which is crystalized in communal memory through "No Irish Need Apply" signs found on places of employment and in newspaper advertisements. Calling the unity of this narrative into question is not to dismiss the very real struggles the Irish did face in coming into the United States, and the very real socioeconomic successes they did have. Those struggles and successes are well documented in many fine histories. Instead, the purpose of this chapter is to use MacDonald's books to examine some things the narrative forgets or leaves out, and the reasons for their erasure. Continued poverty for some Irish Americans, negative effects of alcoholism, 
belief in the supernatural, and a style of living unsuited to capitalism are among the elements forgotten in order to present the narrative as a unified whole.

The popular narrative of the Irish in America acts as a screen for the multiple traumas of famine and oppression at home, migration away from all they had known, loss of language and culture, as well as the destitution of life in urban ghettos upon arrival in their new land. In "Remembering, Repeating, and Working Through," Freud advances the concept of "screen memories," put up in place of traumas too difficult to remember. The screen memory of the Irish-American narrative puts a happy face on all of these traumas, telling the story instead of rising up the ladder through pluck and hard work. The pain of assimilation and cultural loss is smoothed over, but the toughness is remembered. Historian Mary C. Kelley describes what was behind that screen, causing the Irish in America to wait 150 years to publicly memorialize the Great Famine:

Simply put, for Catholic Irish immigrants to be perceived as productive American citizens, they had to overcome negative associations with starvation and disease. On an even more basic level, they had to replace perceptions of themselves as uncultured primitives with indicators of successful assimilation in the United States. Reminders of the Famine could exacerbate popular condemnation of the Irish as premodern peasantry ill equipped for the tasks of American citizenship. (Ireland's Great Famine xv)

The Irish in America had to push down those aspects of themselves that were seen as shameful, but what is repressed will find its way of returning eventually. MacDonald's memoirs give readers a window into the performance of Irish-American ethnicity as the twentieth century draws to a close, in a neighborhood where the screen was used to protect residents from present as well as past trauma. 


\section{The Boston Difference}

While some aspects of the Irish-American experience were similar across the board, others depended on local economic, political, and social circumstances (Meagher 16). It is unsurprising, then, that Thomas H. O'Connor begins his book The Boston Irish with the assumption that "the Boston Irish are different" (XV). He explains the origin of that difference:

If there had existed in the nineteenth century a computer able to digest all the appropriate data, it would have reported one city in the entire world where an Irish Catholic, under any circumstance, should never, ever, set foot. That city was Boston, Massachusetts. It was an American city with an intensely homogeneous Anglo-Saxon character, an inbred hostility toward people who were Irish, a fierce and violent revulsion against all things Roman Catholic, and an economic system that rejected the Irish from the very start and saw no way in which people of that ethnic background could ever be fully assimilated into the prevailing American culture. (XVI)

Over the next three hundred pages O'Connor shows how this hostility to the arrival of the Irish and their continued residence in the city shaped the course of the city's history and the unique ethnic dimension of the Boston Irish. This "difference" will be necessary for understanding MacDonald's Southie, as the cold reception the Boston Irish received would not soon be forgotten. Though nineteenth century IrishAmerican history may seem to have little to do with MacDonald's neighborhood in the 1970s, the ripple effects could still be felt. O'Connor points to the busing crisis that resulted from a desegregation order for the Boston public schools as evidence of a divide within the Irish neighborhoods of Boston (Southie and the similarly demographic Charlestown). MacDonald devotes a chapter of All Souls to how this crisis played out in his neighborhood. Per O'Connor, the divide was between those he calls the "rebel" Irish who had stayed in their urban, ethnic neighborhoods and were 
politically conservative, and the "organization" Irish who had assimilated and moved out to the suburbs and skewed more liberal (297). Of the latter, O'Connor remarks elsewhere, "the new Irish-Catholic business leaders quickly took on most of the characteristics of their Yankee counterparts. They worked hard, invested wisely, prospered greatly, joined country clubs, and moved to the suburbs. There, they joined the exalted ranks of the 'two-toilet Irish' with expensive homes in Wellesley and summer places in Nantucket" (232-233). The divide after the 1974 desegregation order, he argues, "was not a matter of balancing the interests of the Yankee and the Celt, the Protestant and the Catholic — those controversies had long since disappeared" (297), but indeed he has already made the case that the Irish who had moved out of the old neighborhoods and prospered had made themselves into Yankees in many ways. O'Connor makes the point that it was easy for suburban Irish Americans to say desegregation was the right thing to do, since it did not require their children in the suburbs to be bused to black school districts (295).

Samuel Huntington explains that "to define themselves, people need an other" (24). To define who the Irish in Boston would be, they needed the dreaded "Yanks" who ran the city when they arrived. They defined themselves in opposition to them, and at times measured themselves against them. According to Huntington,

How others perceive an individual or group affects the self-definition of that individual or group.... If a large majority of the people in a country think that members of a minority group are inherently backward and inferior, the minority group members may internalize that concept of themselves, at which point it becomes part of their identity. Alternatively, they may react against that characterization and define themselves in opposition to it. (23)

The Irish in America have done both. As O'Connor describes above, the Irish who assimilated and prospered in the twentieth century did so by modeling themselves 
after their "Yankee" counterparts. Over time others did conform to or embrace the stereotypes held against them. The persistence of heavy drinking among the Irish, for example, is a particularly tricky aspect of the ethnicity to explain. Kevin Kenny struggles with finding historical reasons behind the problem that he calls "part of a cultural stereotype as well as a social fact" (231). He says "the historical experience of colonization and displacement might yield a... plausible explanation but it is notoriously difficult to document" (201). Whatever the reason, "Irish-American manhood, in particular, came to be associated with heavy drinking, as distinct from drunkenness; a man who could hold his liquor was truly a man, and truly Irish” (Kenny 201). Thomas O’Connor explains how the pub became a crucial component in the political rise of the Boston Irish, as many activists began their work as bartenders or saloon owners (65). It was also a place where the Irish immigrant community could have social interactions, within their own neighborhood, without Yankee interference (O’Connor 65). The neighborhood pub became a safe harbor in an otherwise hostile city, and drinking became largely inseparable from IrishAmerican ethnicity.

Some Boston Irish, as O’Connor documents, after decades of struggle, rose to political prominence and economic prosperity. Others failed to prosper. Kevin Kenny notes, "If one thing is certain about the twentieth-century Irish-American social history... it is that the Boston Irish cannot be held to typify the American Irish; on the contrary, they were exceptionally disadvantaged" (American Irish 228). Kenny calls Boston, "the city where the Irish had always experienced the most bigotry and had made the least social progress" (American Irish 243). The Irish were slower to move 
to suburbia, especially in Boston (Kenny American Irish 227). O'Connor explains the reason the Irish stayed in Boston in the nineteenth century, when other immigrants took advantage of more space and opportunities out west:

As a people, they had already lost so much by uprooting themselves from their native soil and leaving behind their beloved cultural traditions that they were determined not to lose any more. In the unity of togetherness, there was not only the strength and security they desperately needed in a hostile environment, but also the last opportunity to preserve whatever remained of their Celtic identity. The small piece of turf they had carved out along the shabby waterfront might be unsightly and unsanitary, but it was theirs and they did not intend to give it up. (59)

Fast forward a century, and Kevin Kenny still finds the Irish in the city, not only because they "retained some of their historical preference for city life" (American Irish 227) for the very reasons O'Connor named, but because, even by the midtwentieth century, the Boston Irish had not experienced a significant economic rise across the board. Kenny says, "In Boston...the Irish (along with the Italians) continued to lag behind all other white groups in the 1950s and 1960s, holding three times their share of unskilled laboring jobs, and disproportionately fewer professional, managerial and proprietorship positions" (American Irish 228). In America as a whole, in comparison, "Americans of Irish descent were over-represented, compared with the general population, in law, medicine and the sciences and had clearly left behind most of the disadvantages associated with the earlier immigrant generations" (Kenny American Irish 228). The economic success seen across most of Irish America did not find its way to South Boston.

The people of Southie are fiercely proud of their Irishness. It is through this neighborhood that the Boston Saint Patrick's Day parade marches every year. As an American neighborhood, Southie is guilty of resorting to symbolic displays of 
Irishness. Shamrocks adorn buildings, and green tattoos and clothing adorn people. Some of what they consider their signs of Irishness are internalized stereotypes around drinking and fighting, stereotypes that generations of Irish in America worked hard to reverse in their quest for respectability and full acceptance as Americans. The blame for internalizing those stereotypes cannot just be placed on this one neighborhood. The "Fighting Irish" has become a symbol not only of Southie, but of the premier institute for Irish Studies in the United States, the University of Notre Dame. The ball caps worn by Southie's teens and men reflecting the Notre Dame logo are one result of a long and complicated process of defining Irish ethnicity in the U.S. James Silas Rogers finds that "dividedness lies at the heart" of a people who want to be both tough and respected (Irish-American Autobiography 25). Studying a place like Southie through the literature that comes out of it lends support to Dean Franco's argument that "any account of where cultural identities come from and how they function must necessarily be one that favors impurity over purity, dissonance and a bit of chaos over harmony and order" (22-23). The Irish-American narrative is the story of an ethnic group's formation within the United States. Though often presented as a coherent whole, digging into the literature of Irish America over the last 100 years shows the dissonance to which Franco refers. MacDonald's memoirs are further proof that dissonance is at the heart of any narrative of identity.

Boston attracted Irish immigrants into the twentieth century, including MacDonald's maternal grandparents and one of his step-fathers (the father of his two younger brothers). These people continued to infuse the area with new connections to Ireland. Cultural exchange is complicated, however. It is not just a one way street 
from source country to diasporic community. MacDonald's Irish grandparents brought with them not only Irish ways and stories of growing up in Ireland, but also the trauma of having to leave, forced out by poverty, and the shame that poverty brought them. They brought all of these things to America, where they affected the way they chose to live their lives and the way they interacted with their children and grandchildren. America also spoke to them about what was accepted and respectable. This dynamic, which affected the way MacDonald's grandparents parented, ultimately colored the way their daughter saw the world, which in turn was passed down to her son Michael. Gabriele Schwab's "Haunting Legacies" details this process of transmitting trauma transgenerationally. She explains, "Memories are passed on from generation to generation, most immediately through stories told or written, but more subliminally through a parent's moods or modes of being that create a particular economy and aesthetics of care" (51). If these memories include unresolved trauma, "it will be passed on to the next generation" (49). Using MacDonald's Boston Irish community as an example, one can see how both the joys and the sadness of being Irish are remembered and forgotten. This in turn can show how cracks and fissures appear in the Irish-American narrative, or other narratives of ethnic identity.

\section{Reading Memoirs as Cultural Texts}

Daniel Weinberg calls novels and autobiographies of the immigrant experience "profoundly important documents" to use in the teaching of history when combined with other historical sources (424). He argues that these texts "are immensely valuable for insights into an immigrant's life and his family and community from the 
moment of entry into the United States" (409). Fiction and memoirs "allow the reader a rare intimacy with the actors and events described" in an immigrant community (423). As such, they can get at the experiences of individuals in a way that history books generally do not. Weinberg cautions that the biases and agendas inherent in these creative texts must be taken into consideration. He argues that the same type of careful analysis must be done with these texts as with all historical sources, however. If careful attention is given, "an author's own biases, philosophy, and general outlook may also shed light upon the sentiments of his socio-economic class or community" (412). Weinberg's words provide both a justification and a caution for reading MacDonald's memoirs as evidence for his community's position vis-à-vis the IrishAmerican narrative.

MacDonald is a social activist; he is a champion of the poor and oppressed and he is a crusader against gun violence. He writes his memoirs, especially All Souls, which first tells his family's story, with an agenda of exposing the abuses of those in power - be they politicians or gangsters — and encouraging those who are not in power to band together to fight those abuses. He also writes his memoirs as narratives of healing, with the idea that breaking the silence over past traumas will begin that healing process. He writes All Souls to give a voice to his community. He writes as someone who has experienced the benefits of talk therapy. He also writes as someone who has studied colonial and Irish history. These influences are clear in the way he frames his story, and what he chooses to include in it. His biases could also influence what he leaves out. MacDonald is clearly angry about the effects of drugs on his neighborhood. Drugs were a scourge on his and his siblings' generation in South 
Boston in the 1970s and 1980s. He can place blame on the gangsters who brought the drugs in and the FBI who work in collusion with those gangsters-turned-informants. What he spends less time examining are the effects of alcoholism on the neighborhood, though it is clear that it is also a prevalent problem. Perhaps because alcoholism seems to be the curse of the generation above his, while his generation succumbs to drugs, or perhaps because as Kevin Kenny noted it is difficult to pin down the reasons for alcoholism as a persistent problem among Irish Americans, MacDonald leaves unexplored the instances of alcoholism that he does bring up. He might accept alcoholism as a given, a fact of life in his neighborhood. If pushed further, he might get to the heart of the depression that is at the root of addictions to both drugs and alcohol, and the social problems with which they are so entangled. If MacDonald himself does not take his reasoning so far, scholars of his work could use his memoirs to help fill in a gap in the Irish-American narrative - a gap that looks at poverty and associated traumas as a thing of the past that has been overcome, rather than as a haunting legacy in the present.

\section{MacDonald's Memoirs of Southie}

Michael Patrick MacDonald was born in Boston in 1966, in a country that had already elected and lost John F. Kennedy, but in an Irish-American community that was still clinging to that "small piece of turf they had carved out along the shabby waterfront" over one hundred years earlier (O’Connor 59). Their pride led them to say it was "the best place in the world" (All Souls 2), but their economic circumstances left them little to no options to be anywhere else. In MacDonald's two memoirs, he tells 
his story of growing up poor in the projects of South Boston in the 1970s and 80s, where his family and his neighborhood were decimated by drugs and violence, all under the watchful eye of James "Whitey" Bulger, the notorious Irish-American gangster. MacDonald's mother loses one baby in infancy due to insufficient healthcare coverage just before the author was born, and three other sons in their early twenties due to suicide and ties to Whitey's gang. In addition, MacDonald's sister fell from a roof in an argument over drugs and was left permanently physically and mentally disabled after months in a coma. Countless other young people in the neighborhood died or were left disabled in similar circumstances. This family and this neighborhood experienced unimaginable trauma on a regular basis, to the point where the parade to the neighborhood funeral parlor became a norm rather than an exception. The Irish identity of the neighborhood was a source of pride despite the poverty and violence. This proud Irishness, coupled with an unwillingness to accept that they were poor, became a screen for the trauma the neighborhood faced over and over again.

MacDonald's instinct in dealing with the trauma in his family at first is to bury it within himself. No one wants to hear about all of the death in his family, he thinks. People outside of South Boston would not understand it, and he does not want their pity, or to burden them with his sadness. People within South Boston were numb to it. In the 1980s death became the norm. MacDonald describes the coffin of one of his brothers, a twenty-four year old golden gloves boxer buried in his championship robe: “the rest was the usual for Southie's buried children: Rosary beads, Irish flags, and shamrock trinkets collected from the annual St. Paddy's Day parade" (All Souls 186). That there is anything "usual" about burying children, be they infants or teens or 
twenty-somethings, speaks to the chaos of the neighborhood. His unhealed emotional wounds over the losses of his brothers and his sister's brain injury manifest eventually in psychosomatic symptoms for MacDonald, who in his later teens is convinced he is dying of some undiagnosed illness. Easter Rising details MacDonald's visits to Boston emergency rooms trying to get doctors to take his symptoms seriously, until he reluctantly takes the advice to see a therapist, where he finds relief in telling his story (143-148). He had finally decided to go against his Irish immigrant grandfather's advice to "forget about it now....Forget it ever happened" (Easter Rising 124). Grandpa's advice to MacDonald is a microcosm of what the Irish had been trying to do since they arrived in this country. MacDonald says, "He said to forget that I was from the projects, even though I still lived there. 'Nobody'll want nothing to do with you 'tall if you tell them anything about yourself. Sure they'll only be ashamed to know ye"” (124). So, too, MacDonald's violent, depressed, drug-numbed South Boston exhibits the logical end to the identity crisis that starts with trying so hard to cover up the shame of poverty, and to forget the pain of cultural loss. On a personal level MacDonald reenacts what Irish America has done on a communal level in forgetting the pain and poverty that accompanied their entrance into this country. Both All Souls: A Family Story from Southie and Easter Rising: An Irish American Coming Up from Under address different ways of healing by telling the story of MacDonald, his family, and his neighbors. All Souls is framed on either end with a vigil MacDonald hosts in memory of those in his neighborhood who have died too young. He had just recently moved back to Southie after years avoiding the place, years in which he gained experience as a community organizer and anti-violence 
activist. He helped organize gun buyback programs in other troubled, mostly black and Latino neighborhoods of Boston. He worked with grieving mothers in those communities and in the Irish-American community of Charlestown, which was very much like his own Southie. It is from the mothers in these communities that he gains the strength and courage to finally help the people of South Boston give voice to what they had experienced. Chapter 1 ends with MacDonald at the microphone, trying to voice his own siblings' names. His struggle to speak represents all the years of repressed trauma he, his family, and his community had been through:

I looked up at all the faces of my friends and neighbors who had broken their silence, in a way, by getting up there and saying their loved ones' names through a loudspeaker - in Southie, of all places, the best place in the world. The kids, I thought, trying to remember their names. I knew they were right there in the church, but I still couldn't remember who they were. I looked for them, scanning the entire crowd. But there were so many faces. The crowd stared back at me, and for a long time I looked for my family, among the faces of the living and of the dead. (15)

Not until he tells his family's story in full in the pages of his memoir, does MacDonald appear at that microphone again. The book itself is his speaking for his dead, a way of releasing him from the silence in which he and his community had suffered for decades. The code of the neighborhood had told them "the worst thing you could be was a snitch" (67). This meant they could not speak up about murders that were happening. There was also a psychic cost to admitting that this place they loved, and that they could not afford to leave, was anything but "the best place in the world." They could not admit their poverty, or that they were losing a generation to drug addiction and suicide. These wounds were all unhealed, covered over with a toughness that was the mask Southie showed to the world. That mask is entangled in symbols of Irishness. Even in the church, during a particularly emotional speech from 
a father whose teenage son died of an overdose, MacDonald is not sure if the boy's friends are crying, because “their Fightin' Irish baseball caps were pulled low to cast dark shadows on their eyes" (10). Along with Irish-themed tattoos and tough-guy attitudes, the caps are an attempt to conceal painful emotions behind a veil of Irishinflected bravado. The vigil's goal is to lift that veil so healing can begin. MacDonald says of the vigil, "I'd been scared of this day, the day when we'd all do our small part in breaking the silence, by saying names some people never wanted us to mention" (262-63). On the final page of the book, he is finally able to name his brothers, but only after he has allowed their story to spill onto the pages in between. All Souls is the story of MacDonald's family. In it he tells what is happening to everyone around him. Easter Rising, in contrast, is MacDonald's story of how he copes with it all, his story of personal healing through music and ultimately a reconnection with his Irish roots. It is a story of how he manages to get out of his neighborhood without suffering the fate of so many of his family and friends. It treads some of the same ground as the first book, though not in as much detail about the tragedies that come rapid fire for the family through the late 1970s and early 1980s when Whitey Bulger's drugs are flowing through the streets. As a teen MacDonald wants nothing more than to escape; he says of Southie, "its borders were starting to feel like a noose closing in on me" (Easter Rising 25). He finds his escape in the underground music scene of Boston, a scene at times labeled punk and new wave, but which for him and his friends defies labels. Rather than continuing to conform to the "Southie look" with the perfectly parted hair and turned up collar (All Souls 62), MacDonald at 13 shaves bald patches into otherwise spiked hair, and wears an old 
trench coat, too-short plaid pants, and whatever else he can find from thrift shops or his grandfather's closet. He hangs around downtown Boston, which was only a few train stops but "worlds away from Old Colony Project" in isolated Southie (Easter Rising 1). The friends he meets downtown and the music he is exposed to from the British punk scene open him up to "new ways of looking at things, aesthetically, politically, and personally" (Easter Rising 39). Thanks to this music scene he makes it from downtown Boston to New York City and to California, and finally in his late teens to Europe, where his planned stops include London and Paris. It is on this trip that, at the insistence of his grandfather, MacDonald travels to Ireland. The last third of Easter Rising details two trips to Ireland, one on his own because his grandfather will not wire him money to return from England unless he goes to visit his grandmother's relatives in Donegal, and the second a return trip with his mother, where he learns to see her in a new light.

\section{The Quest for Respectability}

MacDonald's Grandpa and Nana Murphy, "made [him] feel a connection to Ireland and to a world bigger than what [he] had in Old Colony" (All Souls 127). He gets mixed messages about Ireland from his grandfather as he grows up, however. At times, Grandpa tells him Ireland was "a lonesome old place with nothing but TB and dying cows" and that " "the best thing I ever did was leave" (Easter Rising 174-75). At other times, MacDonald remembers,

Grandpa... told me some happier stories, and after the telling, he'd look down and scratch his head underneath his cap, as if doing so would change the subject.... Some of his favorite stories were about the nights when his cousin Dan would sit all the younger kids around him on the floor to hear tell of 
ghosts, banshees, and deaths foretold.... Grandpa said that on the walk home the slightest rustle in a ditch 'would send ye running home for the life of ye'. (Easter Rising 174)

Grandpa is clearly emotionally affected by having had to leave his home, as evidenced by the scratching of his head under his cap, as if to change the subject. He has to put up a screen for himself to say why he left, to forget why he wished he could have stayed. MacDonald notes that the times when his grandfather complains about Ireland have no stories attached to them. These moments are usually in reaction to "too much celebration of all things Irish," but when MacDonald, tired of "all the celebrations of Irish ignorance in Southie" agrees with him, "Grandpa would turn on [him], defending Ireland and threatening to kick [him] out of his house" (Easter Rising 175). Grandpa's feelings are mixed, and that is due to the reasons he first left his home in County Kerry, and then left Ireland altogether after his mother's death. He only shares this with his grandson when he is "weakened by age in his last year" (Easter Rising 204). He tells Michael he had "made up his mind to leave Ireland forever" after he heard of his mother's death from 'blood poisoning caused by a pulled tooth and bad medical care" (Easter Rising 204). For Grandpa this was the last wound inflicted on him by a faltering Irish economy. He had already left the family farm because the cows were dying from TB, but when his mother died, essentially from not being able to afford proper medical care, he could take no more. He waits several decades to tell the full story because he is ashamed of the country that let his mother die this way.

MacDonald's earliest memory is of his own mother crying over the baby she had lost years earlier. This memory is intertwined with the earlier loss his grandfather experienced. When MacDonald saw his mother crying, she was "sitting on the old 
trunk that her father had carried from Ireland when he was eighteen in search of some good luck in America" (All Souls 16). James Silas Rogers calls this scene, "a compelling image of the sadness that has haunted the Irish diaspora" (125). That this is where MacDonald's mother first told him of the infant she had lost, and that for him it is tied up in the memory of his grandfather's trunk and his coming to America, alert the reader to the transgenerational trauma that has occurred. The generations are tied together through losses, more specifically losses that happen due to the impoverished having inadequate medical care. Both deaths could have been avoided if the family had had money. Grandpa's mother was an otherwise healthy woman, with the refrain "Christ, she was strong as an ox"” repeated every time her memory is invoked (Easter Rising 238). There is no way she should have died near middle age of a toothache. Yet she did, and this pushes Grandpa out of Ireland for good, packing his bitter memories along with his other belongings in his trunk. MacDonald's mother is dealing with her own loss, sitting on her father's trunk. Hers is the loss of a baby who had pneumonia but was turned away from the hospital because it "had filled its quota of what were called 'charity cases,' and didn't need to take any more that night" (All Souls 19). Patrick died overnight in his crib (All Souls 20).

In an illustration of how transgenerational trauma is passed down, years after this experience when MacDonald's mother has her two youngest boys, she checks in by phone whenever she leaves the house to see if they are still breathing. MacDonald says, "ever since Patrick, Ma never really trusted that her babies weren't dead when they were just soundly sleeping" (All Souls 148). By this point, Michael is a young teen and in charge of the younger kids when she goes out to play her accordion or 
guitar in pubs. He gets annoyed when his mother calls so frequently, but knows he cannot get her off the phone until he puts her fears to rest, so he puts his hand on his brothers' backs as instructed. He remembers, "I took my time, because I knew that if I came back to the telephone too soon, she wouldn't believe I'd done it" (All Souls 14849). Only a few years later when MacDonald is the one traveling away from home to follow punk bands, he frequently calls to check in, to make sure everyone is alive. This is after losing his brother Davey, and sitting at his sister's bedside for months while she was in a coma. His own traumas have now been heaped on top of his mother's loss of the infant Patrick before Michael was born. He frequently travels to New York City to get away from the violence and pain of Southie, but he calls home collect so much "to make sure everyone was okay" that his mother threatens to disconnect the phone (Easter Rising 117). He worries, especially, about his youngest brothers, because of the uptick in shootings in the neighborhood. A stray bullet had even come through a window and grazed his mother's arm. Now it is his turn to call home and ask his mother, “"Where are the kids?"” and his mother's turn to be annoyed. MacDonald recalls, "She said I should get my head checked" (Easter Rising 118). Two more of his brothers will be lost before he finally takes her advice. If his mother notices here how her son has taken on her own worries, she does not mention it. She would rather he live his life and let her do the worrying, but it is too late; she has already passed on her traumatic legacy.

MacDonald's mother was not the first in the family with a traumatic history to pass on. Grandpa's trunk is consistent with Rosemary Marangoly George's finding that in the immigrant genre, which she argues is a sub-genre of postcolonial literature, 
"Immigrants have to come to terms with the spiritual, material and even linguistic luggage they carry or inherit" (173). Ironically what is carried can actually be a void or loss. It is an emptiness, but it is not weightless. Intangible burdens are often the hardest to bear. The theory of transgenerational trauma explains how families pass down their reactions to such experiences. Family therapist Richard C. Scwartz finds that "some families have passed burdens from generation to generation— - burdens that were first instilled hundreds of years earlier" (138). MacDonald's Grandpa's loss would not have been the first such loss in his family's history either, as the Great Famine hit the rural West of Ireland where he was from particularly hard. At least three generations before his had sent those who could make it to America. According to Schwartz, "whole cultures can carry legacy burdens as the result of being massacred, colonized, enslaved, or impoverished.... Cultural burdens constrain all families within the culture, and in turn burden the individuals within the families" (139). The shame over the impoverished conditions that sent Grandpa and the Famine Irish and others who preceded him to America was not forgotten, but it was silenced. It was only remembered in the way that the Irish in America pushed themselves to never be seen as poor and backward again.

The concepts of attachment theory and dissociation explain how trauma is passed down the generations. Interestingly, though not speaking about immigrants specifically, Doris Brothers says, "I have come to think about traumatized people as exiles, forced to live in a world that they no longer recognize - a world without meaning" (3). The traumatic experience has shaken the person's sense of meaning in the world he or she inhabits. To reestablish a sense of psychic well-being, the 
traumatized person utilizes dissociation, a kind of forgetting or eliminating from consciousness the traumatic event (7). The person may act in ways that protect him or her from experiencing that kind of trauma again even if it is not recalled on a conscious level. For parents or those who become parents years after the traumatic event, this will affect the way they interact with their children, establishing patterns that subconsciously seek to avoid future trauma. They are parenting in fear. Children, attached to their parents and reliant on them for survival, will learn to interact with the world in a way that reflects their parents' fears (Brothers 5). This is the psychological process behind the haunting legacies Schwab theorizes. In MacDonald's family, his grandparents' near-obsession with the way the neighbors saw them, and what news might get back to Ireland, has all the marks of a legacy burden or transgenerational trauma. MacDonald recalls "having to put up with the Irish obsession with 'rosy cheeks' as a kid." He explains, "Nana would spit on a lint-encrusted napkin from the depths of her purse and come at me to rub my cheeks before we met up with anyone who might judge our appearance, usually friends of hers from Ireland" (Easter Rising 224). Anyone in his grandparents' charge was not allowed to look poor, dirty, or sick. Whether they knew it consciously or not, his grandparents were not over the shame that such conditions could bring.

The immigrant generation looks forward to upward progress for their children and grandchildren. They often come to America poor, attracted by the opportunities promised if one is willing to work hard. MacDonald's grandfather put in the hard work as a longshoreman on the Boston waterfront. He eventually managed to buy his own multi-family apartment building in Jamaica Plain, a working class area of Boston. 
Through a series of rebellions and one fateful decision to marry a man who turned out to be an abusive alcoholic, MacDonald's mother does not at first make good on the upward progress thought to await second generation Americans. When she finally decides to divorce her husband, she is living on her own in a nearly all-black project called Columbia Point. Tired of her children being threatened and harassed for being white, she moves into one of her father's apartments in the working class neighborhood of Jamaica Plain. She is a divorcée with eight children ranging from toddler to young teen, and the rules in her household are few. It is there that MacDonald starts to learn that his family does not quite fit in with the other Irish families in the neighborhood:

our Irish neighbors had some American middle-class pretensions that were at odds with the ways of my mother and us kids. And if we ever did anything considered lower-class - like go to the corner store barefoot - in front of someone from Ireland, they might call us 'fookin' tinkers.' This was the worst you could be, according to Irish immigrants, especially once you'd already made it to the Promised Land. (All Souls 30).

The immigrants expected their children and grandchildren to take advantage of American opportunities, and above all to carry themselves with respect. It was not respectable to act low-class. While MacDonald's mother does frequently repeat her parents' warning that "news of her would be 'all over Ireland"” referring to the transatlantic gossip network of which the Boston Irish were part (All Souls 26), she is also a rebel, one who at fifteen, "had thrown open all the windows and screamed 'Fuck the neighbors,' working her parents into a panic" (All Souls 42). Her mini-skirts and children born out of wedlock after her divorce are a constant scandal for her conservative parents, who are driven by the shame of past poverty to strive for respectability above all else. 
As a child MacDonald is torn between this drive for respectability and his love for his family's freedom to be unabashedly who they are. He inherits these conflicting desires from his grandparents and his mother, respectively. He observes that his grandparents "run and hide for the shame" when his mother plays Irish rebel songs on her accordion at the annual Irish Field day outside of Boston (All Souls 28). He realizes that though his grandparents are ashamed of her, "the crowds loved [her]. She made everyone feel that they were at a real party back home. Some even dropped their American middle-class airs, to toss each other around, doing set dances on the dirt in front of the stage" (All Souls 28). Still, even as a young child he is a worrier. He recalls, "I thought all the Irish would talk badly about Ma, as my grandparents said she was a shame to us all with her accordion, and her long hair and short skirts" (All Souls 29). A sensitive and observant child, MacDonald "took over the job of trying to keep things looking whatever way they were supposed to look" (All Souls 33). He has a close bond with his grandmother, but he struggles with her disapproval of his mother's out-of-wedlock pregnancies with his two younger brothers (All Souls 107). His mother's influence wins out, as he learns "from Ma's example to ignore what other people thought" (All Souls 42). When his grandfather can no longer put up with the antics of his daughter and her tribe of kids, for whom "freedom had become the rule above all others" (All Souls 49), he sells his multi-family unit in Jamaica Plain and the MacDonalds are forced to find housing elsewhere. MacDonald's mother works some local political connections and is thrilled to land a low-rent apartment in Old Colony Project in South Boston (All Souls 51). There they find Irish-American neighbors like themselves, who do not mind if their children run through the 
neighborhood barefoot or stay out until all hours, who are not above drinking in their open windows or on their front stoops, and who generally have few middle-class airs beyond pretending that they are not on food stamps or that cockroaches do not crawl through their apartments (All Souls 53).

\section{What Makes Us Irish?}

Helen Murphy MacDonald King, affectionately known by her kids and all of their friends as "Ma," is the heroine of All Souls. She is the kind of person who proves the adage, "truth is stranger than fiction," a character who would seem too outlandish if she were made up. Mother of eleven, Helen King is known for her big red hair, fishnet stockings, miniskirts, spike heels, fringed cowboy jacket, and an accordion held together with duct tape slung over her shoulder. She rebels against her parents' desire for respectability by refusing to contain her body in ways consistent with their conservative, middle class values. Despite a first abusive marriage to an alcoholic, and subsequent failed relationships, she manages to keep her children fed, housed, and clothed through a combination of skillful maneuvering of welfare services and playing

music in the Irish pubs of South Boston and nearby Dorchester. She is the daughter of Irish immigrants who spends summers in Ireland when she is young, so she has a firsthand connection with her parents' culture. Where her parents would like to deny any low class associations, however, Ma embraces what she sees not as low class but as fun, and free. Her Irishness goes beyond the obvious: her playing of Irish music or drawing in a crowd with her story-telling abilities wherever she goes. She has those qualities, but she also has more subtle aspects of who she is that align with characters 
considered authentically Irish in earlier Irish-American literature. She is generous, open-minded, spiritual, and, above all, she is a fighter. Chapter 1 shows how IrishAmerican writers in the post-World War II years align at least the first three of these qualities with an idealized Irish immigrant generation. In MacDonald's memoirs, Ma is that idealized Irish American. MacDonald adds never giving up the fight against forces that might hold one down to the earlier list. His mother fulfills that requirement, as well as the rest. She is in an abusive marriage by 19 and divorced in her early thirties, but she winds up putting herself through Suffolk University for a degree in social work. She becomes a disability advocate when she moves to Colorado later on, but in Southie she raises her kids, plays music at bars to supplement welfare, and eventually cuts hair after going to hairdressing school. Most of her work outside the home as her kids get older is done as a volunteer: cutting hair for the homeless and AIDS patients, doing clerical work at the South Boston Information Center during Boston's busing crisis, assisting mothers of other youth lost to drugs and violence, and eventually fighting on behalf of her daughter and others with disabilities in Colorado. She never looks for more money than it takes to feed, clothe, and shelter her children. In that she may go back to her Irish roots where those living in the communal arrangement called the clachán worked to live, rather than living to work. She is forever giving away what she has in her pocketbook, whether that be what money she has to her kids, holy rocks from Fatima to grieving mothers, or pieces of toast to the homeless people she regularly sees on the street.

Ma is quick to hand out money or food stamps to her kids whenever they ask for it. She brings home food stuffed in her pocketbook from the shows she plays, 
rarely saving any for herself. Beyond her own family, Ma is known for giving whatever she has to the homeless. She never considers herself above anyone who is down on their luck, and does whatever she can to help them. MacDonald attributes his own openness to his mother's example, allowing him to easily befriend an eclectic group of Boston's castaways as a teen. He explains, “Growing up with Ma, who talked to pretty much every homeless person we passed in Southie and sometimes let them sleep on the couch, I was used to characters in the streets" (Easter Rising 71). Sometimes it may have gone too far, as "Ma was always trying to save someone from the gutter, and that's literally where she met some of her boyfriends. They were usually Irish or Irish American and often alcoholic and jobless" (All Souls 35). As soon as she fixes up these men and gets them ready to be productive citizens, she loses interest in them and moves on. Years later MacDonald bumps into a homeless man who recalls Ma as "A good woman" and says, "We never went hungry with her pocketbook full of toast" (All Souls 258). There seems to be an endless supply of these men whom Ma helps, men who are forgotten in the Irish-American narrative of upward social progress.

Ma is also MacDonald's role model as a community activist. When South Boston becomes embroiled in the infamous busing crisis that was a weak attempt to desegregate the Boston Public Schools, she volunteers in the neighborhood Information Center answering phones. At the time Southie stood together in protest of their children being bused away from their neighborhood schools. MacDonald details how at first some of the talk against the desegregation order was about the rich forcing change on the poor neighborhoods that they would not force on their own, but not 
doing anything to improve the schools (76). Soon, however, the protests deteriorated into a "race war" (All Souls 77). Ma told young Michael "it was wrong to hate the blacks for any of this" (All Souls 85) and even though she is against the busing because she wants her kids attending school near home, "she felt like she was kicked in the stomach every time she heard Jimmy Kelly talking about niggers this and niggers that at the Information Center where she'd been volunteering. She said she couldn't get used to that word, no matter how much she hated the busing" (All Souls 118). Ma is open and welcoming to all people, regardless of race. She is disturbed and confused, as her son Michael is, that the neighborhood has turned against black people so violently, instead of against the politicians and judges who put them in this predicament of sending their kids to different failing schools rather than fixing them all. More than a decade later when low-income housing in Boston is the next front in racial integration, Ma "wondered out loud why we were always fighting for the same piece-of-shit schools and cockroach-infested apartments" (All Souls 215). Perhaps not eloquent but definitely to the point, Ma's question informs MacDonald's later activism across races; he realizes that as long as the poor are divided by race, they will only fight one another rather than for better living conditions for all. As Chapter 1 shows, this is a sentiment attached to the heroes of post-World War II Irish-American fiction.

In his teens, when he rebels against Southie, part of what MacDonald is rebelling against is what he thinks is an Irish trait: the racism that is rampant there and that made Southie close in on itself during the busing crisis. He becomes disillusioned with all the trappings of Irishness celebrated in his neighborhood. It is no coincidence that Boston's Saint Patrick's Day parade goes straight through this neighborhood, with 
its "Kiss Me I'm Irish" buttons and drunken brawls in honor of Ireland's patron saint. Shamrocks adorn what his little brothers call the "Irish mafia store," the liquor store that Bulger uses as a front for his drug business. The pro-Irish thinking of his neighbors leads to the exclusion of all others from the "turf" of the neighborhood, and violence against those who enter where they do not belong, most notably African American students during forced busing. This is when MacDonald, sick of the racism and the violence, turns to the underground music scene. Dressed all in black for a concert and walking to the train after carefully avoiding one Saint Patrick's Day parade, MacDonald describes the scene he sees: "The way to the train station was littered with torn green garlands, broken bottles, and the occasional puke. In two places I stepped over blood" (Easter Rising 62). He comes across a lone reveler: "One was sitting on the curb draped in green Hawaiian leis and wearing a huge button that said GOD MADE THE IRISH \#1. He looked abandoned, like he was the only one who hadn't been told the parade was over and that everyone had gone to the bars. He looked up at me and said, 'What, you're not Irish or something?'” (Easter Rising 63), as if Irishness is proven in some kind of contest of how drunk one can get and how much green one can wear. MacDonald rejects what he thinks of as Irishness at this point in his teens, seeing in it only bigotry, drunkenness, and violence.

Drunkenness in the neighborhood is something MacDonald repeatedly remarks upon but never overtly blames for the problems there the way he does Whitey Bulger's drugs. This is a neighborhood where the local "package store" delivers to shut ins, one neighbor drinks openly in his front window day and night, and "an occasional man would stroll down the street, more than one with a bottle in a brown 
bag" (All Souls 51). When the Irish "mafia" takes over the liquor stores in the neighborhood and raises the prices, one neighbor jokes, “"But what can I do? Stop drinking?"'. Clearly that is not an option for him, as MacDonald remembers, "Ma let out a howl of laughter at that one" (All Souls 179). The Saint Patrick's Day parades are drunken fests and bar brawls are regular nightly entertainment, with reenactments of them being performed by neighborhood teens on street corners. MacDonald has to distance himself from Southie to see drinking in relation to the neighborhood's problems. As a teen at a fundraiser to pay for his brother Davey's funeral costs, MacDonald wants a drink so he can "get dizzy and stop analyzing everything" (Easter Rising 42). He has already started to escape the neighborhood into the underground music scene. Even when he does go home, he closes himself off from the rest of his surroundings in his "room with its sealed and blackened windows" and turns up his music to block out the sounds of the project around him (Easter Rising 43). While still at Davey's fundraiser, however, he has to interact with his family and neighbors. He stays sober while he watches them all get drunk in his brother's memory. $\mathrm{He}$ refuses to drink, because he says, "if there was one thing I hated the sight of, especially in Southie, it was alcohol" (Easter Rising 42). That does not stop him from drinking at other times, and his analysis of drinking in relation to Southie's problems does not go much deeper than that scene. That he brings it up so frequently in describing the neighborhood shows he knows drinking is a problem, but it is not one he has fully processed in relation to Irish-American identity in 500 pages of written memoir. 
Along with drunkenness, racism is another trait MacDonald associates with the Irish as a teen, based on his experiences growing up in South Boston. He only finds out that racism is not an inherently Irish trait when he visits Ireland for the first time at his grandfather's insistence. When he first meets his Nana's family in County Donegal, they discuss the differences between America and Ireland. The discussion shows misunderstandings on both sides. His Irish cousins wonder why Americans drink green beer and eat corned beef and cabbage, and then surprise him by asking “"Is it true youse Irish Americans hate the blacks?"” (Easter Rising 189). MacDonald turns the question back around on them, only to be told that they would treat a black person who walked up to the door the same as anyone else; they would invite him in for a cup of tea (Easter Rising 190). MacDonald says, "I was speechless. I had come here expecting to meet the original Irish racist, in the motherland of all ignorance I'd ever known, and was instead hearing of the shame felt over stories of Irish-American racism" (Easter Rising 191). He tells his cousins, he "thought racism was an Irish thing, like green beer and plastic shamrocks" (Easter Rising 190). This is the beginning of MacDonald starting to realize that not everything he had taken to be Irish in Southie could be traced back to Ireland; some of it was invented in America. The particular circumstances of Boston and the United States as a whole, especially around race relations, had shaped the attitudes of his neighbors in sometimes ugly ways. MacDonald is further surprised when he learns that the Civil Rights movement of Northern Irish Catholics was modeled after the African-American Civil Rights movement. As he travels through Derry he thinks, "how shocked my neighbors would be to find out that the Irish Catholics they claimed allegiance with identified as much 
with American blacks" (Easter Rising 198). This is not to ignore that there have been racist incidents in Ireland since MacDonald's first visit in the mid-1980s, especially during the booming "Celtic Tiger" economy when for the first time in centuries immigrants from other parts of the world started moving into the country, and even more so when the economy fell again and jobs became scarce. The idea here is not to idealize the Irish as a whole, but to show that the Irish MacDonald meets on his trip were much more open-minded about race than his South Boston neighbors, and much more apt to see commonalities across people who faced oppression, rather than trying to build walls between them. His first trip to Ireland also rids him of the illusion that the symbolic, green, plastic tokens he has always seen have a connection to Ireland. He finds instead these are objects of Irish America.

The open-mindedness MacDonald discovers in his Irish cousins and the people of Derry and Belfast mirrors the way he feels, thanks to the influence first of his mother and older siblings who had friendships across races, and then of the English punk scene, which teaches him that "the class system instigated racism in Britain" (Easter Rising 73). He studies song lyrics and interviews with British punk rockers, some of whom have "Irish last names...buried underneath invented punk names." They are able to admit that they were poor, and speak out against racism (Easter Rising 73). Poor people are poor people. They should help one another fight oppression rather than turning against one another. Looking even further back in Irish history one can see this strain of Irishness most famously exhibited by "The Liberator," Daniel O'Connell, who fought for Catholic emancipation in Ireland, and argued that the sons and daughters of Ireland should be fighting to abolish slavery in 
the United States. They should be aligned with oppressed and colonized people around the world. David Roediger argues that Irish Americans for the most part rejected O'Connell's plea, and became some of the most pro-slavery Americans instead (135-37). It is clearly inadvisable to paint an entire ethnic or racial group with the same brush, however. There have always been Daniel O'Connells and Michael Patrick MacDonalds and Helen Kings, but in the face of such prominent events as the Draft Riots in Civil War-era New York and the anti-busing riots in Southie, the voices of those who spoke up against racism and who advocated working cooperatively to end oppression were drowned out. Part of MacDonald's agenda in All Souls is to bring those voices back into the story to combat the depiction of Southie as a racist Irish enclave, or the Irish as a whole as a racist people. He does not deny the racism that exists in the community, but he wants to complicate the picture.

As David Roediger's and Noel Ignatiev's work in the area of whiteness studies details, the story of the Irish in America has been tangled with racial constructions from the beginning. In telling the popular story of their rise from having nothing to socioeconomic success, the Irish in America rarely reference others who did not experience the same access to the American Dream, others they may have stepped on or over on the way up the ladder. All Souls, with the Boston busing crisis at its center, does not allow its readers to look away from how celebrations of Irish uniqueness and racism might at times go hand in hand. When MacDonald first moves into the Old Colony project as a child, his first friend Danny shows him the lay of the land, noting specifically where the Old Colony begins and ends, and warning him against crossing into the "niggers"" territory: 
He showed me Carson Beach, and drew a line in the sand right about where we weren't supposed to cross over into 'Niggerville.' Just across that line was the black beach, and Columbia Point Housing Project about fifty yards away. He told me all about Columbia Point, and how there were all these blacks living there with no teeth, bottles of booze in paper bags, and guns and knives. I didn't dare tell him that I was born there. (All Souls 54)

MacDonald comes to find that "nigger" is a word that not only denotes race, but also social class: "It was always something you called someone who could be considered anything less than you" (All Souls 61). Danny labels the people in the D Street project, who are dirtier and do not dress as well as those in stolen clothes in Old Colony, “white niggers” (All Souls 60). Danny is young Michael's guide to the rules and layout of his new neighborhood, mapping out the social hierarchy of South Boston from the perspective of a street smart seven-year-old.

As they walk the neighborhood, Michael finds out that he and Danny are also "white niggers" according to those in the City Point neighborhood of South Boston. The City Point kids are distinguished from those they call "white niggers" and "project rats" because they have fathers at home, and those fathers have blue-collar jobs, where the poorer neighborhoods have either no fathers or fathers who are unemployed. MacDonald notes that the City Point kids "still had the Irish faces, and many had a tough look. But they wore turtlenecks and chino pants, pressed and cuffed just right. Some had Irish knit sweaters, but these were draped over their shoulders the way rich people did. They also wore lots of green, I guess to prove they were still Irish" (All Souls 60-61). MacDonald claims after his tour of the neighborhood with Danny, he "spent hours...trying to grasp this hierarchy of niggers." He wonders "if the Point kids might be niggers to people who'd really made it, like out in tidy West Roxbury or the suburbs that everyone talked about moving to when they won the lottery" (All 
Souls 61). Later on, when MacDonald visits Ireland, he is lumped in with other IrishAmerican tourists by an Irishwoman seated near him on a bus. When he asks how she knew he was American before talking to him, she replies, “"youse are always coming over here with the big bright green jumpers. I bet ye have a big Aran jumper too in that there bag, and maybe some tartan pants to go with it"' (Easter Rising 183). He realizes she is associating him with "the retired Irish Americans in Hyannis with their plaids and Irish knit sweaters wrapped around their shoulders, all fresh and clean as a whistle, like the ads for Irish Spring" (Easter Rising 183). He does not tell her that the green sweatshirt he is wearing is a coincidence, being the only warm article of clothing he packed, and that he had not even planned to be in Ireland before his grandfather insisted he go before coming home from Europe.

What Danny's tour of South Boston and the Irish bus passenger's comments have in common is that they show the way people are defined from the outside, from someone else's perspective, and how that may not match with the way they define themselves. As MacDonald says, "of course, no one considered himself a nigger" (All Souls 61). The pride in being "Irish" in South Boston, or even among the wealthy summer crowd on Cape Cod, has to be displayed outwardly in green clothing and Irish knit sweaters. One might feel Irish on the inside, and his or her face might still bear the genetic imprint of Ireland, but a connection with Ireland has to be proved in the complicated web of race and social class being negotiated by Irish Americans. Irishness, used in this way, becomes a status symbol. As the sweaters get nicer and pants more carefully pressed and cuffed, the relative wealth is displayed. In MacDonald's Old Colony project the tattoos are hand made with a needle and green 
ink, and the only designer clothes worn are stolen from a department store or off the back of a truck. Still, they wear these things as markers of their own ethnic difference, a difference which many think set them apart from and above their African American neighbors just a couple of blocks away. What MacDonald shows through knowing irony is that the very things Danny and others claim are happening over in the African American neighborhoods_-violence and drunkenness and drugs — are prevalent in their own neighborhood as well. The Irish in South Boston use their ethnic identity and associated neighborhood pride as a screen to block out their own problems.

\section{Faith in This World and the Next}

A Christian - in other words, one who follows the teachings of Jesus Christis called to help the poor and embrace outcasts of any kind. A Christian should recognize all of God's children as equal, including "the least" of Christ's brothers and sisters. Citing Saint Augustine, Saint Thomas Aquinas discusses the importance of "mercy" as the "heartfelt sympathy for another's distress, impelling us to succor him if we can" (II. II, question 30, article 1). Though our first priority as Christians is love for God, in loving our neighbor we are showing a love of God. Aquinas says, "the sum total of our Christian religion consists in mercy." He continues to explain that acts of charity bring us closer to God because we are acting in his likeness (II.II, question 30, article 4). The Baltimore Catechism teaches that the Catholic faith is one of "head, heart, and hands" (Groome 178). The "hands" entail the active part of the faith, the doing for others. Thomas Groome points out that only the Resurrection is mentioned more frequently in the Gospels than Jesus's acts of compassion in feeding 
the hungry. Groome argues that all of Jesus's miracles “in one way or another, were prompted by compassion" (182). In reaching out to those in need, Jesus is living what he would have learned in Hebrew scripture, where "justice with compassion" is urged "in response to every form of poverty" (Groome 217). His acts are meant to be a model for those who follow him. Karen Arnold argues that "all religions teach the same thing — compassion." She cites the Dalai Lama as saying that "all faiths teach kindess." These are not values owned by Christianity alone, but if one claims to be a Christian, they are values that cannot be ignored.

As shown in Chapter 1, in Irish-American fiction of the mid-twentieth century, the characters seen as most Irish are Christians in this sense. They are usually the first or second generation in America. They speak out against anyone who abuses the poor, they chastise children and grandchildren for racist speech and what would today be called hate crimes, and they are wary of an ethnocentrism they see emerging among the American Irish in the first few decades of the twentieth century. MacDonald's mother is a true Christian by these same standards. Ironically she has been barred from receiving Communion in the Catholic Church because she is divorced. When his mother first goes to a priest about her husband's cheating and abuse so bad it one time broke her ribs, she is told "'You're a Catholic, make the best of it"” (All Souls 18). She finally gets the divorce when her husband does not show up for their baby's funeral. The divorce stops Ma from going to Church, but not from practicing her faith. MacDonald explains, "I later found out that my mother had her own spiritual life... While we were all off eating candy at mass, she was finding her own secluded spots down by the park, where she could be alone in nature and pray. She considered 
herself Catholic. She prayed through the Saints, and mostly through the Blessed Mother" (All Souls 39). MacDonald acknowledges that his own faith is influenced by his mother. As a child, asked to draw a picture of God, he amazes his mother by drawing what "vaguely resembled a face, but the features were made up of the elements of nature: the earth, the sun, the moon and stars, trees, birds, and other animals" (All Souls 38). It is the judgement of the Church that drives him to seek a faith outside of its walls. He says, "Even as a kid I always felt torn between the Catholic Church and its rules for who's in and who's out with Jesus, and a deeper relationship with God that might be found anywhere" (All Souls 40). A conservative Catholic Church, most concerned with the appearance of propriety, is not relevant for the problems faced by MacDonald and his neighbors.

Ma's finding spirituality in natural surroundings and praying through the Saints and the Blessed Mother harkens back to an earlier Irish Catholicism, before it became Americanized, or more respectable by Yankee standards. Samuel Huntington calls this process "Protestantization" and claims that while most Catholics would not take kindly to that assessment, "in some degree that is precisely what Americanization involves" (96). Peter Quinn describes Famine-era Irish Catholic faith as "a lightly practiced pastiche of Celtic folk belief and Catholic ritual" (166), while James Silas Rogers finds that "cultic Catholicism thrives" in MacDonald's South Boston over 100 years post-Famine though Mass attendance is down (121). Both Ma and her father believe strongly in the healing powers of holy water. They visit Fatima, "where the Blessed Mother had appeared to the three children" (All Souls 202). Ma brings home not only holy water, but also rocks from around the well from which the water springs. 
She carries a jug of Holy Water and the rocks with her in her pocketbook, always ready to help someone in need. MacDonald explains, "Ma was inspired by her own relationship with the Blessed Mother, saying she needed the rocks for some of the mothers burying their kids in Southie" (All Souls 202). Grandpa sprinkles holy water on MacDonald's sister Kathy while she is in a coma. Nurses try to prevent him from getting the water near her because Kathy is suffering skin infections at the time. Grandpa persists, and before he leaves the room asks Kathy to raise her arm. She does, for the first time in three months. She wakes up for good the next week, on Easter Sunday (All Souls 171). According to Rogers,

Such practices might well appear naïve and even superstitious to outsiders. But in considering the trust that $\mathrm{Ma}$ and others place in these objects and practices, it is important to bear in mind the prevailing sense of powerlessness and abandonment in Southie. When Ma shares healing powers of holy water and stones from Fatima, she is at least indirectly asserting some agency in the cure of her own children. (123)

Holy water, rosaries, praying to Saints, the Blessed Mother, and even ancestors looking down from heaven are all in the arsenal of the Irish Catholics from South Boston. As Rogers points out, sometimes their faith is all they have. It is a faith of the people, rather than of a hierarchical organization. It is certainly not a faith that would be called Americanized or modern; it is very similar to what had been practiced in Ireland for centuries.

In addition to holy water and other objects of faith, MacDonald and his family, especially his mother, are believers in supernatural signs and dreams. This, too, is a link to Ireland, and Ma often names it as such. She tells MacDonald he was given his brother Patrick Michael's name in reverse, "because the Irish always said it was bad luck to name a child after another who had died" (All Souls 16). She also believed, 
because the Irish did, that it was unlucky to have a bird in the house (All Souls 185). Before her son Frankie is killed she dreams about a crow flying in and out of her house. MacDonald recalls, "Ma thought for sure after the big black bird invaded our home, that someone would die" (All Souls 185). She has dreams and visions before most of the deaths in her family, including when she buys a dress for her son Kevin's funeral before he dies because she had a vision of him hanging (All Souls 195). Ma is not the only one to have such dreams. Her own mother has a dream about a man in black in her bedroom, which gave Ma "the feeling Nana was going to die" (All Souls 127). Once again she is correct. MacDonald inherits this trait of his mother's too. When he is away in New York he dreams of a Southie "kid" telling him "This shit's gotta stop." He realizes that it was Johnny Baldwin in the dream, a Southie neighbor who had been killed in a car accident. When he gets home from New York Ma informs him that Timmy Baldwin, Johnny's brother, was killed two nights earlier. Timmy's murder was the same night of MacDonald's dream (All Souls 206). MacDonald explains that rather than "religious beliefs... Ma had always taught us to believe in things bigger than that" (Easter Rising 83). For Ma, "the line between this world and the next world had been blurred" (All Souls 242). MacDonald, too, looks for signs from his deceased siblings and Nana, and prays for them to intercede before someone else dies (All Souls 195). Unfortunately Kevin dies anyway, a fact MacDonald knows with certainty while on another New York trip. When he goes to catch a train home a homeless man confirms it, by saying the very words Ma always has put on a ribbon for her buried children's caskets: “"Til we meet again!” (All Souls 197). Ma believes her kids are "in a better place, better off than the rest of us" (All 
Souls 200). Like his mother, MacDonald also finds a thin space between this world and the next. In his case it is a coping mechanism for one loss after another: "Like friends who had moved across the country, the dead were just beyond reach" (Easter Rising 226). Though the Catholic Church building is not where they sought solace in most cases, MacDonald's family's beliefs in the afterlife and the power of prayer, in signs, symbols, and messages from beyond, keep them pushing on when they might otherwise fall apart. MacDonald's memoirs privilege this type of folk belief over the hierarchical constraints of the Catholic Church.

\section{The “Fighting" Irish}

The disturbing thing about the use of the angry leprechaun mascot and the nickname "The Fighting Irish" for the University of Notre Dame's sports teams is that it calls to mind one of the most persistent negative images of the Irish in nineteenth century America. The pugnacious, unruly Irishman, unable to control his own "Irish temper" is second only to drunkenness in the pantheon of Irish stereotypes. Native Americans would never themselves choose a whooping red "Indian" mascot for their own sports teams, let alone those sponsored by a prestigious institute of higher learning. In fact, many Native American groups and others sensitive to their plight have been fighting to have such mascots removed from sports teams and their logos around the country ("Ending the Era"). So it is puzzling why Notre Dame, a prestigious university with a strong Irish American heritage, would persist in keeping a fighting leprechaun as its mascot. One senses a great forgetting of the negative stigma involved in being thought incapable of self-rule because of such temperament. 
On the other hand, there could be an element of thumbing their noses at those who thought of them as inferior. Reading MacDonald's memoirs adds another dimension, as "fighting" takes on a deeper meaning than a brawl that happens after too many drinks, when someone "got his Irish up." MacDonald puts fighting in the context of the struggle for survival that has been going on for centuries in colonized Ireland, and for decades in his own mother's life. He remembers when listening to Ma engage a room with her stories, "We always felt a rush of pride with Ma's favorite line, 'I was always a fighter"' (All Souls 22). She had to fight her husband, fight for her kids, for their housing and their education, not to mention just fighting to put food on the table. Later on she fights side-by-side with another Southie mother, Mrs. Dooley, for some answers for their murdered children. MacDonald shows the positive side of the fighting Irish stereotype when he says of the two women, "They both had it in them to fight, two daughters of Irish immigrant workers who'd raised children on their own in tough housing projects, scraping up money to try to keep them in school and off the streets, against the plans of liberals who knew better and a drug lord who knew best" (All Souls 204). These mothers break the silence of the neighborhood to try to fight for justice for their kids, despite the threat of danger to themselves.

When MacDonald and Ma travel to Ireland together, he tries to tell her about all the Irish history he has learned at college. She does not want to hear about the sadness, but her favorite parts are "the bits of history about putting up a good fight" (Easter Rising 223). This struggle to survive, to fight oppression for what is rightfully theirs, connects Ma to her ancestors. It screens out the sadness she would rather not remember. MacDonald says "fighting to the end had always been the family creed" 
and "surrender was a luxury, one to be ashamed of" (Easter Rising 98). MacDonald connects his and his mother's insistence on fighting injustice to the fight against English oppression in Ireland. On this trip where he learns to understand his mother better, MacDonald's big takeaway is what about Southie is Irish after all. It is not the shamrocks or the green tattoos, those put on marks of Irishness. It is instead, "that the Irish forget nothing, even across generations. Even in Southie, where most of us Irish Americans knew nothing about this place, we still somehow remembered that you never surrendered the fight" (Easter Rising 198). MacDonald's work shows that memory can be evidenced in habits of being, long after the reasons for those habits have been forgotten. Unfortunately for Southie, sometimes the targets of their fights, such as outsiders who might dare walk or drive through the neighborhood, were illchosen. The larger fight, for dignity despite poverty, for proper schools for their children, for the right to tell the truth about their dead and to prevent similar deaths in the future, for the well-being of their neighbors, for justice, is what MacDonald comes to see as "the real Southie, the good Southie" that he loves (All Souls 259). It is clearly part of his agenda to rescue the reputation of "the good Southie" from the larger depiction of the neighborhood as inherently bigoted and backward.

\section{Conclusion}

MacDonald's memoirs provide evidence that well into the $20^{\text {th }}$ century there was an Irish-American community where the residents had not achieved American prosperity, where there was still a version of communal living that harkened back in some ways to pre-colonial Ireland, and where the "what would the neighbors think?" 
attitude of the middle-class "lace curtain" Irish was more or less checked at the project boundaries. Looking at what has been suppressed in the Irish-American narrativethe narrative advanced largely by now privileged Irish Americans - it is clear that trauma, fear, and shame were great motivators for their suppression. Though sometimes what is remembered in Southie on the surface is empty symbol and stereotype, beneath the surface there are ways of being that are Irish and Catholic. Thankfully it is not only trauma that is passed on, but also ways of coping and helping others, not to mention ways of connecting as humans through songs and stories. The contradictions that run through the neighborhood exemplify the dissonance in the Irish-American narrative. Tough faces belie big hearts. Bravado masks poverty. Screen memories go up where the real story is too painful to bear. There will never be one narrative that tells the whole story of any one people. In studying the gaps in the narrative, however, one can see psychological needs that created it. One can also understand, that if this unique Irish-American experience exists in South Boston, many other Irish-American stories, as many as there are immigrant communities or even individual immigrants, must exist as well. By reading memoirs and fiction of immigrants and their descendants, whether Irish or not, it is possible to grasp just how many different and sometimes contradictory elements go into a diasporic narrative. 


\section{CHAPTER 4}

\section{Ireland Writes Back: Roddy Doyle, John Ford, and the Construction of the Irish-American Narrative}

Because emigration has been a principal trauma of the Irish experience for the past two centuries, it is no surprise that it has often been the subject of contemporary Irish writing. In recent decades, Irish authors have written about the emigration experience, and its effects on both sides - those who leave and those left behind — with at least as much fervor and interest as Irish-American authors. That is to say, Irish fiction writers have picked up on emigration as an integral part of the Irish story. In doing this, they have considered how emigration fits into the Irish narrative more than Irish literary critics or theorists of nation have done to date. The theorists of Irish national narrative referenced in this study—David Lloyd, Declan Kiberd, and Seamus

Deane-all mention the vast number of emigrants from Ireland, especially in the Famine era of the 1840s-1850s, but the narrative does not follow them after they leave. Once they have gone they have left the Irish national narrative. Novelists, in contrast, can allow their protagonists to travel back and forth across the ocean, to explore emotional truths found in the emigrant's experience. In writing his novel The Dead Republic, Roddy Doyle not only wrote an emigrant's story, but tackled the construction of Irish and Irish-American identity in the process. In The Dead Republic, multiple groups are shown to have contributed to the construction of Ireland's national narrative. Contributors to the narrative come from both inside and outside of Ireland. Doyle has crafted a novel that illustrates how entangled the influence of diaspora is with the way Ireland presents itself to the world. 
At a book reading in Boston in 2014, Roddy Doyle was asked about his transition to historical fiction for his The Last Roundup trilogy, of which The Dead Republic is the last installment. The trilogy is a departure from most of his work set in contemporary Dublin. Doyle responded that the story of Ireland's last 100 years, as told through his protagonist Henry Smart, who in Forest Gump-fashion shows up at every major event of that period, is not historical fiction at all. He said that this "history" is alive and well in Ireland today. The Irish are still living it, because those key events (the War for Independence, the Irish Civil War, emigration and return) are still a part of every Irish person's communal and familial experience, if not their own personal experience. In viewing the past as alive in the present, Doyle is espousing a mindset that refutes a historicist insistence on calendrical time, what Dipesh Chakrabarty calls, "the enabling condition of modern historical consciousness, the capacity to see the past as gone and reified into an object of investigation" (243). Instead, Doyle is living on Irish time, where the past is not "another country...caught in a time lag" as the self-professed "modern" observer would like to think it is (Lloyd Irish Times 1). When time collapses in this non-linear fashion, stories of the past are still relevant; people of the past are still present. Communing with the past, then, is a very natural and everyday occurrence. Thus Doyle's resistance to the term "historical fiction"; he insists he is at all times writing fiction of the Irish present.

Just who the Irish are is the central question in the third book of The Last Roundup trilogy, The Dead Republic, in which Doyle writes a meta-narrative of Irish identity that crosses from Ireland to America and back again. Through this novel, Doyle shows, ultimately, how the Irish-American diasporic and Irish national 
narratives are intertwined. For this reason, Doyle's novel serves as the last and perhaps most important text in this study of how the Irish-American narrative has been constructed. It is a capstone for everything considered in this study so far. To properly see just how insightful Doyle's skewering of the national myth is in The Dead Republic, we should first reconsider the theory on what a "nation" is, and then consider how national narratives are built on what is remembered, as well as what is forgotten. Nation, Ernest Renan tells us, is a modern idea. It is "a soul, a spiritual principle" (19), based on memories of a glorious past, stories of heroes who are the nation's ancestors. The nature of this kind of communal memory is that it leaves things out; it prioritizes some memories over others, in creating a notion of nation that serves to bind its citizens together. About 100 years after Renan, Benedict Anderson famously theorized nation as an "imagined community." Anderson builds on the work of Ernest Gellner, who argues, "Nations as a natural, God-given way of classifying men, as an inherent though long-delayed political destiny, are a myth" (49). Anderson quotes Gellner on the same topic: "Nationalism is not the awakening of nations to selfconsciousness: it invents nations where they do not exist" (6). After 100 years more experience with the concept of nations and nationalism, Gellner and Anderson are able to state directly what Renan had alluded to. Nations are made up stories, made up with the political purpose of keeping a people together, and, as Anderson points out, giving them an idea for which they are sometimes willing to kill and die (7).

If within established geographical bounds the nation has to be imagined into being, the process must be even more creative in diaspora, where migrants and their descendants are separated from their homelands. Migrants are cut off at the point of 
their departure from the present of that place they call home. Gellner calls diasporic nationalism "a distinctive, very conspicuous and important sub-species of nationalism" (101). Here Gellner is mainly talking about diasporas of people who no longer have a territory to call home, most notably the Jewish diaspora, but Kevin Kenny argues convincingly that at least the Famine-era Irish emigrants qualify as diasporic people (32). It was what Kenny calls a "powerful sense of banishment and exile" (40) felt by the Famine-era Irish that fueled how they saw themselves in relation to their position in the world. Not only the Famine Irish, but their subsequent generations, carried on this "sense of banishment and grievance." The blame for what was lost to them, that grievance of which Kevin Kenny writes, was placed on the English and their handling of the Famine, as well as their discriminatory colonial practices in general. At least until Irish Independence, subsequent waves of Irish emigrants could still rightfully blame their plight on the colonial power that kept them poor and disenfranchised. The newer immigrants to the United States, in the early 1900s for example, would have added fuel to the already smoldering dislike of the English, an attribute that Kenny finds common in the Irish in diaspora. This resentment of the English became a central feature of the Irish-American narrative, thanks in part to the sentiment best expressed by John Mitchel: "the Almighty indeed sent the potato blight, but the English created the Famine" (qtd. in Kenny 31). Kenny indicates that Mitchel's claim was an oversimplification, but still acknowledges that this sentiment, "became foundational in Irish-American ethnic identity: that emigration was a matter of British-imposed exile rather than voluntary choice" (31). It is the perception of being wronged that matters in the creation of narrative, not 
necessarily the historical accuracy of the claim. This is what it felt like to those who left during the Famine years, and that feeling is what was passed on to subsequent generations.

What Irish Americans did in creating the narrative of who they were involved remembering the abuses they suffered at the hands of the English, and remembering the beauty of their homeland, while forgetting any other problems that may have existed there. What results is a nostalgic view of Ireland that is constructed in the minds and hearts of Irish America, a national narrative in diaspora. Catherine Nash explains it is this nostalgia that drives the popularity of genealogy in America today, with third, fourth, or even beyond fourth-generation descendants of Irish migrants searching for their roots:

In one way, this settler genealogy of old-world ancestry reflects a nostalgia for an imagined time when place, identity, culture and ancestry coincided. Where you lived was where your ancestors had lived and there was no dissonance between cultural identity and location. This is the ideal of bounded places, deep roots and shared culture that characterizes the modern notion of nation. $(179-80)$

Though Nash correctly acknowledges there is no such thing as pure culture, Irish Americans distanced from the site of their cultural inheritance can feel rootless. Again, in the construction of narrative, it is perception that matters, and the perception of Irish Americans is that something crucial to their identities was left in Ireland. What Nash explains about Irish Americans' quest to trace their roots provides a concrete example to support Maurice Halbwach's, Paul Ricoeur's, and Pierre Nora's theories on how human beings remember. Maurice Halbwachs tells us that human memory is social. He says, "the greatest number of memories come back to us when our parents, our friends, or other persons recall them to us.... It is in society that 
people normally acquire their memories. It is also in society that they recall,

recognize, and localize their memories" (38). How disorienting must the immigrant

experience be, then, cut off from the people who share and help us recollect our

memories, especially when there were not easy opportunities for staying in touch. Not

only are memories social, but according to Paul Ricoeur, they are tied to places:

It is on the surface of the habitable earth that we remember having traveled and visited memorable sites. In this way, the 'things' we remember are intrinsically associated with places. And it is not by chance that we say of what has occurred that it took place. It is indeed at this primordial level that the phenomenon of 'memory places' is constituted, before they become a reference for historical knowledge. These memory places function for the most part after the manner of reminders, offering in turn a support for failing memory, a struggle in the war against forgetting, even the silent plea of dead memory. (41)

Without a sense of place, in other words, there is nothing to tie memories down, to anchor them. Pierre Nora argues that we are living in a time without memory, as opposed to pre-modern societies that he says lived their memories and traditions. According to Nora in pre-modern societies there was no distinction between present and past, but now memory has "been swept away by history" (2). The modern sense of history has assigned the past to a prior time, causing us to need what Nora calls "lieux de mémoire" or sites of memory to stand in for "the vast fund of memories among which we used to live on terms of intimacy" (6). Nora argues that "reconstructed history" (6) replaces the memories earlier societies "dwelled among" (2). In theorizing the way people have developed along a pre-modern/modern divide, Nora is using the historicist reasoning Chakrabarty critiques, but what is instructive for this chapter is how he connects memory to place. Emigrants leave their memory places behind, leaving future generations without sites that could tie them to their 
family's memories. After the immigrant generation, Irish Americans would have to construct their history around an imagined version of Ireland as a whole, since most had lost touch with particular sites. They needed to be able to imagine a home that would welcome them back in order to heal the transgenerational trauma caused when their ancestors left. When nineteenth and early twentieth century emigrants left Ireland, it was most often never to return. This cut them off from the people and the places with which their early memories were associated. It is no wonder that genealogical research has become so popular to a community still trying to fill in the gaps left in their group memory caused by what their ancestors perceived as forced emigration from the places and people they had known for centuries.

Luke Gibbons, discussing a form of nostalgia created by the political and social upheaval caused by imperialism, migration, and industrial revolution starting at the end of the eighteenth century, says that for migrants at that time and since,

A new form of nostalgia sought to anesthetize the pain of loss and uprooting by severing the connection with the past as it was actually experienced. Distance, it was found, lent enchantment to the view and, through the healing powers of imagination and hindsight, the past was idealized to the extent that it receded from the present. Memory, then, became a way of disconnecting from, rather than connecting to, the past.... (49)

What Gibbons is describing here is at least as much forgetting as it is remembering. It is forgetting a painful past as it happened, and erecting in its place a "memory" that was more pleasant, as Henry Smart sometimes wishes he could do. Sigmund Freud calls such shields from painful memories "screen memories." He says, "In some cases I have had an impression that the familiar childhood amnesia, which is theoretically so important to us, is completely counterbalanced by screen memories. Not only some but all of what is essential from childhood has been retained in these memories.... 
They represent the forgotten years of childhood as adequately as the manifest content of a dream represents the dream-thoughts" (148). Paul Ricoeur applies Freud's concept of screen memories as part of individual psychology to collective memory; Ricoeur says they operate the same way in both realms (451). What Freud says of painful experiences from childhood being covered by screen memories could then be applied to the early years of a community, for example the Irish when they first arrived in great numbers to the United States. The Famine Irish and those who followed in the decades after left poverty and oppression; the same greeted them when they arrived on America's shores. Their ancestors a century later preferred to imagine a homeland that had been lush and green, supportive and pleasant. It is significant that what brings up Gibbons' discussion of nostalgia is the subject of his book, John Ford's 1952 film, The Quiet Man. It is a retelling of the making of that film that is at the heart of Roddy Doyle's The Dead Republic. Gibbons continues, "dimmed by romantic nostalgia, the past is recreated in the image of a dream-world and wrapped in a golden haze which all but removes the source of pain at the outset" (49). In Doyle's book, Henry Smart much more succinctly calls this aspect of Ford's famous film and its depiction of Ireland, "sentimental shite."

One part of this sentimentalism is a longing to be able to return home. Kevin Kenny also cites that desire as a feature of diaspora (though he points out that not many Irish Americans actually took the opportunity to return to Ireland when it gained its independence from Great Britain) (61). Though Irish Americans may have been too comfortable as they moved up the American socioeconomic ladder to leave for good, they still had a desire to return to Ireland, at least to visit, if not to stake some 
claim to the ancestral lands. Retracing one's roots is a way of laying claim to the land without taking ownership of it. It is a way of saying, "this is where I am from. This is where my people belong." Catherine Nash explains this impulse in her work on genealogy:

Travelling to Ireland to trace Irish connections or to visit the place which ancestors left brings different genealogical and geographical imaginations together.... Despite what may have changed, the experience of the topography, the shape of a hill, the sight of the horizon is often imagined as a shared physical experience that links ancestors to their descendants across time and difference. The visit to Ireland is a pilgrimage and mission in honor of ancestors who could never go back. (188-189)

Nash also comments on how return ties into colonialism. She continues, "For the descendants of Famine and post-Famine migrants this return is frequently framed by discourses of colonial dispossession, forced exile and the trauma of displacement" (189). Put in this light, the Irish in America, especially of the generations Nash named, qualify as diasporic people. Their perception, which is at least partially supported by history, is that they were forced from their homes by English colonial policies. This becomes the center of loss on which the Irish-American narrative is based. A trip "home" to Ireland for the ancestors of those exiled is often seen as a healing journey, one that makes up for wounds of the past. If they cannot reclaim Ireland, or their piece of it, in reality, they can at least see the places they were from, taking pictures and maybe a piece of "the ould sod" home with them.

According to David Lloyd, "Control of narratives is a crucial function of the state apparatus since its political and legal frameworks can only gain consent and legitimacy if the tale they tell monopolizes the field of probabilities" (Anomolous 6). Doyle's The Dead Republic plays with who is in charge of this narrative. It is not 
Henry Smart as a private citizen, as much as he thinks he is for a while: "The Quiet Man and the Provisional IRA - the two faces of Ireland, and they were both invented by me" (193). It is not Hollywood, or Irish America, at least not acting on their own. They do influence the definition, but they do not own the narrative. It turns out that the Irish-American vision of Ireland comes close to the way Irish nationalists wanted Ireland to be seen:

Nationalism had certainly helped to create a new idea of Ireland, which had great and liberating consequences. But it also created a version of Irishnesscompounded of whimsy, romantic populism, Celtic nativity heroisms, and a belief in the salience of the artist in political as well as cultural affairs-which was restricting and as subject to caricature as the old colonialism has been. This was not surprising since the nationalism was a response to the colonialism and since it had been led by the Anglo-Irish section of the people, the colonials themselves. (Deane 203)

By the time Eamon deValera's Catholic-dominated government is in charge of a newly independent Ireland, it is hard to call it Anglo-Irish, but that government still, as David Lloyd goes to great lengths to argue, mimics British colonialism. In touting Ireland as rural and Gaelic to claim a difference from England, it repeats some of the same stereotypes England has used against Ireland for centuries. Those then become the same qualities Irish America holds dear in its vision of a homeland. It is hard to know who is in charge of the myth-making, when the imperial narrative, the national narrative, and the national narrative in diaspora are all so entangled. Oddly enough, they wind up telling very similar stories.

One explanation for why these narratives could be so similar can be found in theories of globalization. Arjun Appadurai argues that technologies that allow for global communication are leading us to an age beyond nationalism. He says, "the nationalist genie, never perfectly contained in the bottle of the territorial state, is now 
itself diasporic....it is increasingly unrestrained by ideas of spatial boundary and territorial sovereignty" (160-61). Media, including film, is one of those technologies that has allowed the "nationalist genie" to escape. As if speaking directly about The Quiet Man, Appadurai says, “deterritorialization creates new markets for film companies, impresarios, and travel agencies, which thrive on the need of the relocated population for contact with its homeland. But the homeland is partly invented, existing only in the imagination of the deterritorialized groups, and it can sometimes become so fantastic and one-sided that it provides the fuel for new ethnic conflicts" (49). Emigration and exile cause cracks and fissures in the national story; they break up the traditional modes of transmission of culture. They distance the emigrants and their descendants from their geographically-tied memories. New technologies have allowed for greater transnational travel and communication, replacing traditional national narratives with narratives that are transnational, too. Like Paul Gilroy's Black Atlantic, the Irish Atlantic has become a source of near constant back and forth cultural exchange. Goods, people, ideas, film, television, music_all have moved back and forth with ease, especially as the twentieth century went on and technologies became more sophisticated. While Declan Kiberd says that England helped invent Ireland to be its opposite in the early centuries of invasion (1), over the past century it is fair to say that America has helped to reinvent Ireland, as the home of so many of her exiles and emigrants, as a source of funding for revolution, and later as a source of great wealth from tourism. In the reception of The Quiet Man around the world but especially in America, where it became the vision of the emigrant's dream come true, this transatlantic influence is perfectly captured. 


\section{The Quiet Man: John Ford's Irish Dream}

Luke Gibbons' book on The Quiet Man explains that the film drove the tourism industry in Ireland, as was Ford's intent, as evidenced by letters between himself and his friend Lord Killinan of Ireland. Bord Fáilte's (the Irish tourism board's) founding coincided with the release of the film, and other fictionalized and romantic stories of an emigrant's return home were made as advertisements to attract tourists. According to Gibbons, The Quiet Man "became virtually a master narrative in Bord Fáilte's... promotion of Ireland abroad, especially for the American market" (91). Yet Gibbons defends Ford's over-sentimentalized view of Ireland, equating it to another technicolor marvel of the time. Disputing what critics of the film call an oversimplified portrayal of Ireland, he says that no one complains about the oversimplification of Kansas in The Wizard of $O z$ (12). Yet The Wizard of $O z$ did not set out to be a tourist film for Kansas, the way Gibbons himself shows that The Quiet Man did for Ireland. There were different purposes and intents behind the ways these two locales were depicted. The only reason it matters that The Wizard of $O z$ is set in Kansas is that we need to believe a tornado could blow through, and that they would have a storm cellar for Dorothy to try belatedly to enter. It otherwise could be set anywhere, since the bulk of the film takes place in the fictional Oz. Coming home to Ireland, on the other hand, is the very point of The Quiet Man. It could not have been set anywhere else. It had to be Ireland and, specifically, the romanticized-because more purely Gaelic, and less anglicized-west coast. Adrian Frazier explains how beautiful sights from three different counties are combined to make one fictional 
Innisfree (226), and how the cinematographer only filmed on sunny summer days, to further heighten the attractiveness of the locale (225). Both Frazier's and Gibbons' nonfiction treatments of the film support Doyle's fictional version, in that The Quiet Man became, to use Frazier's words, "the beautiful travelogue that Ford intended" (226). In Hibernian Green on the Silver Screen: The Irish and American Movies, Joseph Curran also compares The Quiet Man to other fantasy films, saying "The vision enchanted millions who saw it; it is as captivating as $\mathrm{Oz}$ or Brigadoon and almost as unreal" (79). Curran says that Ford, "was not trying to portray social reality but to recreate a myth" (79-80). In that he was successful on both counts.

Like Gibbons, Frazier also defends Ford's sentimentalization of Ireland, and his use of familiar stage Irish stereotypes to depict its people. Frazier says "The Ireland of The Quiet Man is an assembly, and a magnificent one" (226). "But," he says, "Ford did not just idealize Ireland, he critiqued it" (226). Frazier's first evidence of this critique is that the opening scene in the train station, during which the Irish characters cannot get out of their own way long enough to give John Wayne's Seán Thornton directions to Innisfree, is an homage to Lady Gregory's plays, in fact using some of the Abbey Theater actors. Frazier says the film borrows Lady Gregory's "signature combination of condescension to, and appreciation of, Irish country people" (227). It is hard to see this as a critique of Ireland on Ford's part; instead, it seems an echoing of familiar stereotypes of the Irish as foolish and even infantile, not to mention lazy, since the train conductor is, as usual, woefully behind schedule. Frazier excuses the Abbey Theater actors from hamming it up as Irish country people, saying "Abbey actors had always done that" (236). Again Luke Gibbons comes to Ford's 
defense. He argues, "Ford's irony, humour and over-the-top treatment should be sufficient by itself to place much of what we see in The Quiet Man between the visual equivalent of inverted commas. The depiction of stereotypes, romantic escapism or nostalgic sentiment is not of itself an endorsement of them" (19). It is unclear, however, whether the vast majority of the viewing public, especially the IrishAmerican viewing public who were so clearly the target audience of the film, would have recognized these subtle critiques of Ireland, or these ironic treatments of overused stereotypes of the Irish as simple, lazy, backward, and drunk. For all of these stereotypes are on full view, and at the base of The Quiet Man's comedy.

The example of just one character from the film, Abbey veteran Barry Fitzgerald's Michaleen Oge Flynn, is enough to make this case. Providing most of the comic relief, Michaleen embodies many of the stereotypes of the Irish. Fitzgerald hammed it up in the role of this matchmaker/cart driver/tour guide/friend to Seán Thornton. This loquacious little man does most of his talking when his throat is adequately quenched, either with porter or whiskey. He cannot quite live up to his responsibilities as chaperone for Seán and his beloved Mary Kate as they step out on their first date. Instead, Michaleen is distracted by the nearest pub. Fitzgerald's Michaeleen is quite funny, to be sure, but he only enforces the depiction Americans had in their heads of the Irish - funny and cute, but not to be handed much of any authority, and, of course, hopelessly dependent upon alcohol. Joseph Curran says of Ford that he, "relied on the well-defined 'stage Irishman' in his various guises. In fact, Ford may have done more than anyone else in Hollywood to perpetuate Irish stereotypes, particularly that of the hard-drinking boyo" (75). 
Gibbons complicates the many criticisms lodged against the stereotypes in the film, however, saying that it was conservative voices both in Ireland and America who complained about them. The "lace curtain" (respectable) Irish Americans did not want their reputations besmirched by this depiction of an Irishman like Michaleen Oge. They did not want to be associated with him. At the same time, Gibbons says complaints about stereotypes came from, "civil reformers in Ireland, whether of the national or imperial stamp, as they sought to integrate the refractory culture of the lower orders into their own narratives of the nation" (15). Gibbons' point is welltaken here. The reaction against these less desirable features of Irishness came mostly from those who, in America, wanted to assimilate into the middle class, and in Ireland from those who wanted to be a "modern" nation and move beyond such backwardness. Gibbons argues that "the most difficult stereotypes to uproot are not those that falsify reality but those that are grounded in truth, and which also go one step further in purporting to show the 'essence' of things" (96). In other words stereotypes might have some grounding in reality, but it is painting them as essential to the national or racial character that is the problem.

\section{Memory and Forgetting in The Dead Republic}

In The Dead Republic Henry Smart suffers the forgetting so common to immigrants, who risk losing parts of their past as they spend more years away from home. For Henry it is a literal amnesia, due to ill health after years spent homeless and undernourished. The reader attuned to the theory of memory and forgetting will also see how, away from his community and his native land, Henry would begin to 
lose his memories. When he is brought back to consciousness on the John Ford film set he stumbles upon after years of an itinerant lifestyle, Henry has to reclaim his past by writing it down. He jots down names of siblings that come back to him in a little pebbled notebook he carries with him, so as not to lose them again: "I tried to remember the names of the brothers and sisters. And the dead ones, too, the ones who'd gone up to join the first real Henry in the sky. There were girls and boys, one a year, for years, but I couldn't see any. I could only remember one name. -Victor, I said" (41). His Irish siblings, dead of poverty and disease, are nearly forgotten but not quite, once Henry starts to write his own narrative. This is much like what contemporary Irish novelists are doing, writing the forgotten people back into Irish history, after more than a century of cultural amnesia. From the first novel in the trilogy, A Star Called Henry, the Henry Smart known to readers has believed he could see his older brother Henry, who had died, as a star in the sky. In The Dead Republic Henry looks for his other siblings there, too: "I looked up at the stars. There were so many of them—all that death and none of it hidden. Every dead infant and toddler; they were all up there - the starving, milkless, tortured. There were millions of them, more than millions" (54-55). There are so many dead children because Doyle is representing not just one family, but all Irish children gone from poverty and associated diseases, not to mention starvation, which brings back the ever-haunting specter of the Great Famine. The Famine is the trauma that caused the cultural amnesia in the first place. Emigration is a second trauma - a dislocation and a lossthat compounds the first. 
Though Henry struggles to recall his siblings' names and write them down lest he forgets again, The Dead Republic also suggests there is pain in remembering. Later in the novel when Henry is reunited with his estranged daughter, he expresses with envy, "She'd managed what I'd failed to do when I'd gone to America; she'd invented herself, new-born and ready, with no history or anything dragging her back.... She was an American" (271). Henry might, at this point, welcome his daughter Saoirse's seemingly uncomplicated American life, without the baggage of Irish history weighing him down. When memories are painful, sometimes amnesia may be a blessing. This forgetfulness has allowed Irish Americans to move up the American social ladder without much regret. They have created a screen memory that has allowed them to leave behind the more traumatic parts of their history, and in their place to construct a nostalgia-tinged memory that would allow them to retain a fondness for their ancestral homeland without being responsible for the poverty there, or feeling guilt for those left behind.

Yet as Henry learns more about his daughter, whose name in Irish means freedom, he discovers her relationship with Ireland may be more complicated than he originally thought. She had not entirely left it behind. In fact, she was regularly in touch with both her mother, who had returned to Ireland, and her Uncle Ivan. She was also involved in Irish Republican political activity behind the scenes. Henry's assumption that she was an American, plain and simple, echoes what other Irish characters have thought of him upon his return home — that he must be a "Yank" because of his leather boots (96-97) — as well as what Henry thinks of Irish-American filmmaker John Ford. Henry does not believe Ford when the latter says that he is "not 
really American." Henry responds, "You are," but Ford replies, "No.... I'm Irish. But I guess you'd dispute that" (120). This represents what the Irish think of Irish Americans - in essence, that the American is a much more prominent part of their identity than the Irish. Misunderstandings abound when we make judgments about other people's identities. It is confusing enough to know ourselves, never mind to presume what attachments someone else has to their various versions of home, whether "home" is where that person lives, or from whence his ancestors hailed.

In fictionalizing the making of The Quiet Man, Doyle skewers the IrishAmerican narrative that has glossed over the complexities and ugliness of Irish history to glorify and sentimentalize their ancestors' homeland. John Ford put the screen memory that was already in Irish-American minds on the big screen literally. He both represented and reinforced how they wanted to remember "home." The fictional John Ford, in Doyle's book, wants desperately to be connected to an authentic Irishness. He asks Henry to call him Seán (31), and he laments Henry's inability to speak to him in what should be his native language:

-- It's a big day, Henry, said Ford. -- Agus, conas atá tú inniú?

-- What?

-- It's fucking Gaelic, he said.

-- I know that, I told him. - But I don't know what it means.

-- Hear that, Meta? he said. - It's fucking tragic. (33)

Though the fictional Ford is a bit of a joke for Doyle — nostalgic in the extreme, the typical Irish American who wants to retain his idyllic vision of the green fields of Ireland - here, in a comical scene, he brings up a valid point on the destruction caused by colonialism. It is "fucking tragic" that Henry cannot answer the simplest of questions (“And, how are you today?") in what should be the native language of 
Ireland. Henry Smart was born in 1901, 70 years after the English National School system was put in place in Ireland, and 50 years after the Famine that killed or drove away so many Irish speakers. To make matters worse, Henry is a poor boy from Dublin, with very little education. Dublin, inside the English "Pale," had long been accustomed to speaking the invader's language. During Henry's childhood Ireland was still under English rule. He is two decades too early for the compulsory Irish language instruction that came after independence. The language was lost to him. It is shameful that an Irish American would know it better than he does. This is a good example of what the novel does: it makes us laugh, in part because of Doyle's obscenities, but at heart it is a serious postcolonial novel questioning the fallout of both British colonialism and the nationalism that chased the colonial administration out.

Though not the primary screenwriter for The Quiet Man (Frank S. Nugent adapted the screenplay from a short story by Maurice Walsh), Ford is listed as an uncredited contributing writer (imdb.com). In Doyle's telling of the making of the film, Ford is the driving force behind what gets put on screen, what gets added in, and what gets left out of Walsh's original story. In The Dead Republic, Walsh's story was supposed to be blended with Henry Smart's life story to create the film. Doyle's fictional John Ford finds Henry's life as a former IRA man fascinating. The problem is Henry's life would not sell. It is not clean enough. It involves Irishmen who turn against one another over the Anglo-Irish treaty; it involves being run out of Ireland by his own people, his own former comrades. It also involves a gritty early existence on the Dublin streets, and even in its network of sewers. Henry's life is not exactly the 
green technicolor dream that Ford wants to portray. What Ford wants to portray, according to Doyle, is "The emigrant's dream. Rural, Gaelic, the simple life" (127). Ford knows the reality of Ireland; he is familiar with its history. Still, per Doyle, he would rather project the nostalgic vision of Ireland that he carries in his mind, while at the same time pleasing the censors and making something marketable to the viewing public. Describing the Ireland in his head, the image he cherishes, Ford tells Henry, "I was Irish from the start. It was the stories my parents told. And the dancing and music and the drink. We were never really American. We were Irish but Ireland was thousands of miles away. And fifty years away. I grew up loving a place that didn't fucking exist" (119). Doyle puts these words into the mouth of a son of Irish immigrants, one with the power of a celebrated career as a Hollywood director behind him. He can and does share his vision with millions.

Doyle's characterization of the fictional John Ford is instructive for anyone interested in how immigrants and their immediate descendants look back at the lands from which they originate. As a Hollywood director and writer, Roddy Doyle's John Ford exhibits the characteristics Salman Rushdie claims for Indian writers in exile:

It may be that writers in my position, exiles or emigrants or expatriates, are haunted by some sense of loss, some urge to reclaim, to look back, even at the risk of being mutated into pillars of salt. But if we do look back, we must also do so in the knowledge - which gives rise to profound uncertainties - that our physical alienation from India almost inevitably means that we will not be capable of reclaiming precisely the thing that was lost; that we will, in short, create fictions, not actual cities or villages, but invisible ones, imaginary homelands, Indias of the mind. (10)

In Innisfree, Ford literally does create a fictional village, one that puts his "Ireland of the mind" on screen. On the falseness of this village, Henry remarks with Doyle's characteristic humor: "There was a granite high cross at the top of the road into the 
town. I stopped there, and looked down rural Ireland's idea of a street. I leaned against the cross. It fell over with me onto the road. The fuckin' thing was made of wood, as real as a Fort Apache cactus" (102). The hollow Celtic cross prop is a representation of Irishness in the film. Like the American version of Ireland, this cross looks impressive, but lacks substance. In the film the real Irish town of Cong had been transformed into Innisfree in the same way Ford turned his California sets into the American Old West. As Doyle points out, each locale was equally fictional; Ford had also invented America. Henry remarks of Ford's westerns, "He was building America, with John Wayne and the desert. He was giving Americans the history they wanted" (92). When Ford was not busy creating the American national narrative, supporting manifest destiny with his cowboy and soldier heroes, he turned to his true passion: Ireland.

Adrian Frazier's understanding of Ford's impulse in creating The Quiet Man, as expressed in his book on the Hollywood Irish, echoes Doyle's depiction of Ford as a sentimental son of immigrants, longing for his vision of home. Frazier argues, "That there was an element of fantasy in Ford's Irishness does not mean that it was unreal or unimportant to his identity. It suggests the opposite: that his Irishness was a wish in need of fulfillment, a gap in his American identity that had to be filled" (16-17). Ford is able to share with the world the vision of Ireland he had, and in so doing he could confirm and solidify the same vision held by so many children and grandchildren of Irish emigrants around the globe, not the least of which would have been his IrishAmerican audience. The Dead Republic shows how The Quiet Man becomes a central icon in the creation of the Irish-American narrative, providing a beloved image of 
"home" for so many who could not travel back to Ireland, and the impetus to travel there for those who could. As the Maureen O'Hara character says of Ford in The Dead Republic, "No one is as sentimental as the Irishman who was never there in the first place" (76).

Multiple ways of returning "home" to Ireland are shown in The Dead Republic. This is where the meta-narrative Doyle has constructed gets complex. Ford had returned to Ireland, and tells Henry about his trips there. The occasion of finally filming The Quiet Man in Cong, County Mayo, is what forces Henry to make the return trip home after years in exile in the United States. Then there is the fictional Henry (himself already Doyle's creation), whom in the film is called Seán Thornton, and is played by John Wayne. Adding to the complication is that there had been a character in Maurice Walsh's 1933 short story “The Quiet Man," named Shawn Kelvin. Thornton in the film was supposed to be an amalgamation of Kelvin and Henry, according to Doyle's novel. The homecomings of Henry Smart and Seán Thornton could not be more different, however. While Thornton arrives to sunshine and pastoral beauty, Henry arrives to rain, and dampness that soaks so thoroughly his wooden leg expands, causing his shin to be "pale and blotched" (4). The dampness also, after 29 years away from home, brings back his Irish cough. He says, "I lay there and felt the country crawl into my lungs. I felt it bubble and turn" (4). Instead of the lovely voice in Thornton's head of his mother, reminding him of glories of his family cottage, White o' Morn, Henry finds the only trace of his wife's family's cottage, the scene of his marriage during the War for Independence, to be one gate that remains standing. The rest had been destroyed and buried, as if the cottage never existed. 
Henry says the absence of the house, right down to the walls and the foundation, "felt like another death" (6). He cannot understand why there was no trace of it. The lone standing gate, like Henry's painful wooden leg, is an imperfect prosthetic, but it is much better than nothing. In this scene the wooden leg and the gate are both props that keep Henry up: "I walked back now through the field. My own wooden leg was groaning, protesting, biting into the folded flesh.... But I grabbed the gate and the top rung was there, exactly as cold as it should have been. I'd held that gate before, even if the path from the gate to the house was gone. The gate was real; it felt like sanity" (6) The gate is a prosthetic for memory, to use Bernard Stiegler's term, a reminder of both the fleeting joy of his marriage ceremony and the war that caused it to be performed in haste. Its presence amidst the striking absence of the cottage assures Henry that his memory is not failing him. On his way off the property Henry realizes the house has been purposefully erased by his wife's cousin, Ivan, who would have been the heir to the land and one of the former comrades who ran Henry out of Ireland. Ivan was trying to control the narrative of the War for Independence that would be remembered in those parts, and he was writing Henry out of it: "Ivan had razed the house, then he'd buried it too deep to be remembered" (7).

Henry, outcast from Ireland, and returning to find no one he knows (at first), is unsure of his memories. His memories are tied to the land but the landscape has changed with the missing house; he finds it "weird" (6). It is disorienting because nothing is there to confirm his memory at first. He is looking for the wall of the cottage. He says, "I'd come to see the wall, maybe put my hand against it, break off a piece of whitewash, put it in my mouth and taste it. But just to see it - that would 
have been enough. To find its foundation in the grass, to feel it in the sole of my good foot. Proof" (7). Everything else is the same, he says: "The few bits of trees, the yellow furze, even the cows had stayed more or less put, where I'd left them in 1922" (6). He is sure of his familiarity with the place. He says, "I knew exactly where I was going, where there'd once been a stone step. I could feel it in my muscles; I could feel the knowledge sing through me" (6). Still, it is only when he holds the gate that it feels "like sanity." Without the people there to confirm his memories, and with the landscape changed by the razing and burying of the house, Henry's memories are called into question. He cannot be sure, as Ricoeur says, of what "took place" until he locates the gate that confirms his memories. The gate will have to substitute for the missing house and the missing people. Henry sits down next to the gate and remembers the man he used to be: "I was once a man called Henry Smart. I was born in Dublin, in 1901, and I fought for the freedom of Ireland. I married a beautiful woman and we tried to save Ireland together. There was a baby, a girl called Saoirse, born when I was in hiding. I went into exile when my comrades decided that they needed me dead" (8). He continues on through the story of his exile in America, but it is the gate that brings it all back. It is all he has left to remind him of his story.

Seán Thornton's return to his family's still-standing cottage in The Quiet Man, in contrast to Henry's, brings back memories of idyllic country days, life on the farm, and fun with relatives and neighbors. Ironically, Henry's return more closely resembles Ford's own attempted return to his cousin's cottage in Spiddal in 1921, which had been burned to the ground by the Black and Tans, according to Luke Gibbons. In Walsh's story, too, Shawn Kelvin's return is also not as happy as Seán 
Thornton's. He returns from America to find himself the last of the Kelvins, and the Kelvin land unlawfully annexed to the farm of Big Liam O'Grady. As Doyle so clearly shows by making Henry's return a dark shadow, the more realistic double of Seán Thornton's return, Ford had sanitized Ireland to give it mass appeal. In Ford's Ireland Irishmen do not fight Irishmen. The enemy is clear cut, and that enemy is English. Ford tells Henry that his earlier film about Ireland, The Informer, was a commercial failure because no one wants to see Irishmen shooting one another. "We all know the fucking truth but who wants to pay for it?" Ford explains (122). Of the characters in The Quiet Man, Ford tells Henry, “They're Irish. They can't be bad. Outright bad, Limey bad" (93). Ford has to simplify the story to put on the screen what will sell. He will not display the messiness of Irish history, for commercial reasons, but also because as an Irish-American himself, he wants to remember Ireland in this uncomplicated way. The Quiet Man is a love letter to the country of Ford's parents' birth, and evidence of Ford's own wishful nostalgia, even though he knew the Ireland he depicted in it was not real. Even Henry Smart had to admit the advantages of that nostalgia: "Ford had invented a place where the Irish could be at rest. Where fists didn't hurt, where drink did no damage, where there was no real pain to hide. A monstrous fuckin' lie, but a nice one" (124).

Ford's "lie" became a film near and dear to the heart of a generation or more of Irish Americans. These Irish Americans came of age during or soon after World War II, at just about the time the Irish in America were finally getting comfortable with their place in their adopted country. It is also, as I explain in Chapter 1, the time that Irish-American novelists start to write novels that show an anxiety over losing an 
authentic connection to Ireland, as the flight to the suburbs from concentrated urban Irish neighborhoods had begun. The Quiet Man became how these newly suburban, middle class Irish Americans saw Ireland; it matched the Ireland in their minds:

The idealized idea of Ireland as an inviolate isle beyond the sea pervades their consciousnesses and shapes their identities. Ireland's four green fields became a compensatory visionary landscape, a lost Eden, for Irish-Americans who forgot the trials of starvation and political repression which their ancestors escaped, for Irish-Americans who refused to believe reports of the hardships and isolation Ireland continued to endure during and after World War II. The romantic dream of Ireland illustrates the latent idealism and vulnerable sentimentality among Irish-Americans but also reveals their susceptibility to denial and deceit. ( O’Connell 265)

The Quiet Man is the lie that Irish Americans want to believe. They flock to theaters to see it, and later it becomes a favorite in homes on VHS and then DVD. It is now available to stream on Netflix. It is a lasting vision of Ireland. Some see it as a quintessential Irish film, but Doyle exposes how American it actually is. The narratives written by those who stay in Ireland - Roddy Doyle and Maurice Walshshow a much more complicated vision of the place than does the Irish American Ford. As Irish Americans became comfortable enough to have money to travel, The Quiet Man in part is what drew them "home," and the Ireland of the film is the Ireland they expected to see. Again, as Renan says, forgetting becomes useful in the creation of national narratives. Further away from the source, a national narrative in diaspora can be even more forgetful with the goal of preserving the desired, uncomplicated and unsullied, image of the homeland. The trauma of leaving home, of starting out impoverished if not starving, is pleasantly covered by the big screen memory created by John Ford. 
Doyle could have left his critique at just the Irish American penchant for a nostalgic view of Ireland, where everything is green and romantic, and there are no problems of poverty and disease. He did not stop there, however. As the decades unfold after Henry returns to Ireland and settles in as a caretaker at a national school in one of the new suburbs north of Dublin, he gradually begins to realize who was pulling the strings all along. He sees that like The Quiet Man, the story of the Republic of Ireland is also a fictional narrative. Irish Republicans have created their own myth. Ireland wanted to portray itself to the world as a nation that had gained its freedom from Empire, and then prospered. It solved all of its economic, health, and social problems. Henry knows from his first day back in Ireland to film The Quiet Man that this is not true: "The village, Cong, was outside the castle window. I'd walked through it and I'd seen the hungry faces; they hadn't changed since 1922. But they wouldn't be making it into the picture" (124). When he makes it across the country to Dublin, again he is disappointed at how little progress had been made in 30 years, as he hears the sounds of coughs coming from the tenements where he grew up. He says, "I began to wonder if my fight [for a free Ireland] had really been a total waste" (133). When he travels north to the suburbs, however, he is impressed at the new middle class. Dubliners had moved up and out of the city. Young mothers looked healthy and had leisure time. Eventually, though, he begins to see that things were not what they seemed: "I woke up. I began to see and hear. I still saw the progress, and smelt it. It came from the walls, and from inside the classrooms. But I knew I wasn't in a republican heaven. Bad lungs weren't left at the gate, and bad bastards occasionally crawled off the farm and became teachers" (144). The Irish 
government was working hard to show a good face to the world. In 1966, Henry hears Eamon de Valera's radio address on the fiftieth anniversary of the Easter Rising: “"We cannot adequately honour the men of 1916 if we do not strive to bring about the Ireland of their desire"' (159). For 50 years, the Irish nationalist program was to will this desired nation—rural, Gaelic, Catholic, and prospering —into being, strategically forgetting all of the elements that did not fit that narrative.

Not a decade later, Henry gets caught up in this scheme, when he is a victim of the Dublin terrorist bombings in 1974. His past as an IRA man comes out, and soon he is a hero being paraded around Republican events by the incarnation of the IRA during The Troubles in Northern Ireland. To Henry's surprise, it turns out the IRA had known his whereabouts and been watching him (and providing for him, by getting him his caretaking position) since he stepped foot back in the country. Not only that, but it turns out John Ford and Frank Nugent were not the only ones who had a say in what went into The Quiet Man. The development that the IRA had been the driving force behind the writing of the film the whole time is a surprise both to Henry and the reader of The Dead Republic. The IRA man who visits him (a fictional Gerry Adamstype), explains how his organization ultimately decided what the world would see of Ireland. He also tells Henry that the original script he had written with Ford, which would have shown the true grittiness and the complicated mess the War for Independence and the Civil War were, "would have been the last nail in the coffin of republicanism." He also tells Henry that Ford made the film, "to show a place worth fighting for...something beautiful that was going to be destroyed.... de Valera's Ireland.... Comely maidens and the rest of it" (316). Henry disagrees with the IRA 
man that the film is Ireland, to which the man responds, "Oh, it is. As far as millions of people were concerned. And they travelled here to see it with their own eyes. And we tried to live up to it. Certainly, you people down here in the Free State did. Bord Fáilte and the rest of it. Ireland was The Quiet Man" (317). According to the IRA man's logic, public opinion would support the IRA if they believed "the Brits" were out to destroy the Ireland in their minds. "That's what people saw," he says. "Bloody Sunday, the hunger strikes. Heaven destroyed. All because the Brits wouldn't pack up and leave" (317).

The Dead Republic ends with Henry, at an improbable 110 years old, looking forward to living another six years to 2016, when he believes that Ireland will once again be reunited, north and south, and that the country will finally be free. It is the result he fought for from 1916 to 1921. It is the result that keeps his Cuman na mBan rebel wife hanging onto life though in a coma, herself well over 100, waiting to hear that England has left Ireland. Henry finally tells her that lie to let her slip away. At the end of the novel, also the end of Doyle's The Last Roundup trilogy, it becomes clear that Henry has been a physical embodiment of a century of Irish history. Henry understands as much after he is rediscovered by the public in 1974: "The thought was mad-Irish history was all about $m e "$ (205). Henry had lived every aspect of twentieth century Irish history. He lived in a Dublin slum as a British colonial subject. He had no grasp on his own mother tongue. He fought for a free Ireland. He was chased out of that "free" Ireland by those who would be satisfied with less than complete freedom. He lived the life of an exile in America. Returned from exile, Henry becomes an Irish hero, the "republican dead" (182), a "living saint" for the 
cause of Irish nationalism (250). Henry says himself, that the people "looked at me and saw their country" (175). Henry takes part in his own myth making, or so he thinks; all the while the IRA were using him to advance their own narrative. Together with the government of the Republic, they have invented Ireland. The IRA man tells Henry, "The armed struggle has been about ownership of the definition of Irishness" (313). He says the war was about "The copyright. The brand" (313). When he asks Henry, "Who owns Irishness, hey?" he answers his own question: "Sinn Féin.... We've battered all other definitions into submission" (314).

\section{Conclusion: Entangled Narratives}

What Roddy Doyle does by fictionalizing the creation of The Quiet Man is critique the narrative that John Ford set forth; in doing so he is critiquing the foundation of Irish-American identity, which so often centers on a nostalgia-tinged longing for home. Ireland as the most beautiful place on Earth is our lost birthright, thanks to the Brits and their damned imperialism. So goes the creation story at the start of the Irish-American narrative. Seán Thornton gives us the fantasy that we could go back, reclaim what was lost to us—our cottage, our customs, our language, our beautiful red colleen. Our pints and our songs and our stories. From the opening pages of The Dead Republic, Roddy Doyle's Henry Smart bursts that beautiful bubble created by Ford. In this novel Doyle is trying to rewrite, or at least give massive editing to, the narrative that has been written in the popular imagination of Ireland, especially in Irish America. 
And yet The Dead Republic also proposes just how entwined the Irish nationalist and Irish-American narratives are. Even Henry, who was trying to tell the "true" story of his life, eventually realizes he was complicit in letting Ford's version of the narrative make it to the screen. The national and diasporic narratives are different, but codependent; they provide mutual fuel to one another in constant transatlantic exchange going back at least to the 1840s. Emigration is a key feature of Irish history over the past 200 years. It involves profound psychological loss for those who stay and for those who leave. Emigration is a breaking up of the Irish family, a loss of the country's young people, a loss perhaps only eclipsed by the loss of language over the same time period. Even after famines ended in Ireland, emigration continued. Rare would be the Irish family left untouched by it, even to this day. It is no wonder that when contemporary Irish novelists write historical fiction, or of how history haunts the Irish present, they frequently turn to emigration as part of their narrative.

Emigration is central to the Irish story, and it also where the Irish-American story begins. Many contemporary Irish novelists explore not only the lives emigrants start overseas, but also how they continue to interact with family members in Ireland, through letters and visits home. Emigrants continue to influence the Irish culture while at the same time their Irishness contributes to their new American (or other national) culture. Roddy Doyle overtly discusses the creation of both the Irish national and the Irish diasporic narratives in The Dead Republic. The most impressive thing about Doyle is that he manages to craft a postcolonial novel that dissects nationalism, diasporic nostalgia, and the destructive effects of colonialism while at the same time being funny. The novel is not without the tragedy of families torn apart, or 
of little boys dying from TB, or of the wife who will not die until her husband tells her Ireland is free. Still, it is so funny in places that it does not feel like the typical postcolonial novel, a genre that is often relentlessly bleak. The humor should not stop scholars of nationalism from taking a serious look at what Doyle has done here. They may indeed turn to this novel to see a complex example of how a national-even a transnational—cultural identity is imagined into being. They may even find that they understand a little better, at novel's end, how a diasporic community constructs its narrative from what has been remembered, and what has been strategically forgotten. 


\section{CONCLUSION}

Writing about the narrative of Irish America in the age of "fake news," "alternative facts," and social media memes offers some interesting challenges and opportunities. Especially in the month of March as I wrap up this project, when the Internet experiences an uptick in "Irish" memes that celebrate drunkenness and “shenanigans," this topic seems more urgent than ever. One particularly egregious set of memes focuses on the myth of Irish slavery, circulating images purporting to be of Irish slaves in the United States and the Caribbean, with captions explaining how bad the Irish had it and that essentially "we are not complaining." The message behind the memes is to target African Americans for complaining about the effects of racism and the legacy of slavery and ask, "“We got over it, so why can't you?"” (Stack). In making this comparison from Irish-American success to still impoverished African American communities, the implication is that there is something inherent in those communities, as opposed to the Irish, that has kept them from rising. Liam Hogan is one of many scholars of Irish history trying to debunk these memes (Stack). Scanning Hogan's Twitter feed one can see he faces an uphill battle, as the memes and articles citing dubious sources about Irish slavery keep coming. They are circulated much faster than he can respond to them all, by people who think they are an accurate reflection of history. Hogan points out their many flaws and how they twist Irish history for racist American ends (Stack). They also of course ignore the ugly and complex history of race in the United States. These memes and "news" stories are the far (or "alt") right extension of a diasporic narrative that recounts with pride the Irish 
rise from what it sees as the bottom of American society (conveniently eliding actual chattel slavery) to the top.

There is in this insistence on telling the story of the rise from abject poverty to the economic success of the American Dream what Homi Bhabha calls "the ghostly repetitions of other stories" (Location 224). For even in the ultimate symbol of IrishAmerican triumph - the election of John F. Kennedy to the presidency — the ghostly presence of earlier traumas are operating under the surface. That this event was greeted as such a moment of triumph can only be explained by how far the Irish had come in the century plus since they first arrived with nothing, starving, to American shores. The celebration of JFK's election is evidence of pride in the first Irish Catholic to hold that office, but also a feeling of making it in spite of all the ways Irish Catholics in this country were first held back. Haunting this triumph, the way it haunts so many Irish-American texts, is a ghostly repetition of the Famine and postFamine poverty, the shame associated with that poverty, and the oppression that kept the Irish impoverished at home and that sent them fleeing from it. For Irish Americans, what they never forgot of the Famine was their suffering at the hands of the British. Similarly, the "No Irish Need Apply" signs that come up so frequently in the story of the Irish in America represent the discrimination faced when the Irish immigrants first arrived in their new country. These signs served as symbols of oppression the Irish faced at home and in diaspora, and are seared into the early chapters of the Irish-American narrative, making the rise to American success all the more impressive, even heroic. 
The notion of "success" is an interesting one to consider as this study comes to a close. Early in his detailed history of the Boston Irish over the last 300 years, Thomas O'Connor remarks that one of the reasons Irish Catholics did not come over to America in large numbers sooner despite poor conditions at home was "they were more inclined to accept their lot in life than to try to rise high or achieve much" (19). This is a value judgement that depends on the writer's definition of achievement. For the Irish of course had for centuries achieved much in art, music, and poetry. As explained elsewhere in this study they had a vibrant communal life in the clachán. What they had achieved may not have looked like much by colonial or capitalist standards, but what if enjoying time with family and neighbors is considered an achievement? In his acclaimed history of the Irish in my home city of Worcester, Timothy Meagher discusses the positive influence of the national school system in Ireland, established by the government of the United Kingdom in 1831. He applauds the "dramatic improvement in the literacy rate" of the Irish thanks to these schools that "dominated education in Ireland" by the last decades of the nineteenth century (Inventing Irish America 28). Meagher discusses these trends in Irish education because they make for more educated immigrants arriving to Worcester by 1900 . What he does not mention is the near erasure of the Irish language as a result of those same schools, and the oral literary tradition that went with it. It is not easy to get outside a mindset of capitalist modernity to see that success can be measured in ways other than financial, or to get out of a colonial mindset to see that there are other types of literacy aside from that of written English, or other ways of teaching aside from a brick and mortar school building. Adapting to these economic, linguistic, and 
educational changes brought most of the Irish in America upward social mobility and comfort. I do not know any who would trade what they have for what their ancestors gave up, but it is worth re-membering the parts of the story that are left untold, including that there is more than one way to define success.

That some Irish came to the U.S. by choice, that some came as skilled laborers with some financial means, that some who came were Protestants-all of these things are also gaps in the main Irish-American narrative. So, too, are the Irish in America who did not rise, who stayed impoverished and therefore did not fulfill the American Dream. Michael Patrick MacDonald's neighbors in the projects of Southie only get their story told because he tells it. The popular narrative of Irish-American success leaves them out. There are also gaps in the story of how the Irish helped improve working conditions in the United States. Though it is remembered that the Irish were heavily involved in the early labor movement in this country, it is forgotten that those first unions were not exactly "united," in that they excluded non-whites, women, and at times other, newer immigrant groups (Kenny "Labor" 362). It is also conveniently forgotten that any of those labor organizers, now remembered as heroes of the working class, could have had any interest in socialism, which is still treated like a dirty word among Irish Catholics who came of age in the mid-twentieth century, along with many other Americans.

As I wrote this dissertation, and discovered a repetition of characters in midtwentieth century Irish-American fiction involved in radical politics who were painted in such a sympathetic light by their authors, it brought back to mind an exchange with my father that I just thought was funny at the time. It was early in my teaching career 
and for some reason, though I do not normally discuss my curriculum with him, I mentioned that I was preparing a lesson on Marxist literary theory. He yelled, "That's bad! You can't teach that!" His reaction caught me off guard. I do not think I even probed him for a reason behind his position, since he finds many things "bad," from bacon to driving after dark. I joked with my students about his response. I dismissed it as his being elderly and conservative. He is the definition of "old school." It is only now that I am starting to put together his generation, his Catholicism, his Irish heritage, and his exclamation that anything to do with Karl Marx is bad. My father's generation was not far displaced from generations of Irish Americans who faced discrimination in employment in the United States. My mother remembers her uncle being passed over for promotion at the mill where he worked because he was Catholic. My father's parents, as mentioned in the Preface, did not name him after Irish hero Robert Emmet for fear of discrimination he would face when he was born in 1922. It is not just in my family that the legacy of discriminatory treatment still appeared well into the twentieth century. By 1900, "the dominant trend in IrishAmerican trade unionism... was away from radicalism and toward conservatism" but it had included a strain of radicalism in the decades before that (Kenny "Labor" 361). When the mostly Irish Boston police force went on strike in 1919 and the response of the city was to fire them and replace them with Yankees they found more trustworthy, "the Irish of the city viewed these outspoken sentiments as proof that old-time Bostonians continued to regard them as an inferior group, still not fully assimilated after nearly a century" (O’Connor 193). Peter Quinn describes the people in his IrishAmerican neighborhood of the 1950s as "still in the defensive crouch they'd arrived in 
during the Famine, still sensitive to the distrust and dislike of real America, to the suspicions about our loyalty and supposed proclivity to raucous misbehavior" (275). The suspicions around loyalty, traced back at least into the 1700s when Irish Catholicism was seen as incompatible with democracy because of Catholics' allegiance to the Pope (O’Connor 28). That Quinn remembers his community still in a "defensive crouch" speaks again to the haunting legacy of the condition in which the bulk of the Irish arrived in the United States, and their treatment when they arrived. It is this legacy that drives Quinn's mother as well as the characters with social aspirations in the works of Edward McSorley, Mary Doyle Curran, Elizabeth Cullinan, and even Michael Patrick MacDonald's maternal grandparents, to put such a premium on respectability. It is also likely this same legacy that drove Joseph McCarthy to "out" anyone whose political leanings he saw as "un-American."

It is this drive for respectability that fuels the change in the American Catholic church. In the 1840s Boston's Bishop Fitzpatrick emphasized the keys to acceptance would be "Americanism, loyalty, and the maintenance of good order" combined with “avoiding liberal causes and radical associations" (O’Connor 68). One hundred years later, "Catholic leaders such as Bishop Fulton J. Sheen and Cardinal Francis Spellman had become fervent American nationalists and the Irish-American Catholic became the prototype of the patriotic American" (Huntington 96). Involvement with a radical social movement would only undermine the acceptance the Irish in the United States had worked so hard to achieve. This is the legacy behind my father's "teaching Marx is bad!" comment. It is a transgenerational legacy of the fear of rejection, combined with the idea spread by people such as the policeman Larry McDermott in McSorley's 
Our Own Kind that socialists were out to bring down the Church. The roots of these fears had been largely forgotten by the time I came of age late in the twentieth century, but there they were, still haunting my father.

It was not just around radical politics that the legacy of early discrimination against the Irish in the United States lingered. In Boston, at least, "the bitter antagonisms of the 1840 s and 1850 s created a wall of separation that would continue to keep the two communities [Irish Catholics and the Protestant "Brahmins"] at arm's length until well into the second half of the twentieth century" (O’Connor 94). Thomas O'Connor explains that discrimination based in the "Puritan revulsion of all things Catholic," would not soon be forgotten in Boston. In response, "for generations to come, Catholic children would be reared in the catechism of hate that instructed them never to forget the bigotry of Protestants, who had confined them to institutions and asylums, and the cruelty of the Brahmins, who had posted on factory gates and workshop doors the signs that proclaimed for all to see: 'No Irish Need Apply"' (94). Again, those signs are cited so frequently in the rhetoric of any conversation about Irish oppression in America that they have to be seen as prosthetics for memory. They are reminders of the overall treatment of the nineteenth century Irish at the hands of a Protestant majority.

When I read in O'Connor's Boston Irish that parochial schools were founded because Irish Catholics were incensed that public schools were teaching their children Protestant prayers and having them read from the Protestant Bible (80), it brought back another memory for me. Again in a seemingly innocuous conversation with my father, this transgenerational legacy of painful memories popped up. I mentioned that 
I bought my then pre-school aged daughter a children's Bible, and that she liked to have me read it to her. I thought he would be pleased to hear about his granddaughter's religious training. The small Bible with simplified stories and cute cartoon pictures seemed innocent enough to me. Again, however, I had raised my father's worry meter. "You better make sure that's a Catholic Bible," he said. "How would I know?" I asked. He advised, "I would ask a priest.” To appease him, I did ask my parish priest the next time I was at Mass, and he assured me that this was a concern of the older generation, that most of the discrepancies between the two Bibles were inconsequential, and that it was doubtful they would be of issue in a preschool Bible anyway. To my father it had been a theological crisis.

The history behind these conversations with my father that I found funny but he found so concerning points to some of what has been forgotten and what has been remembered in the Irish-American narrative. The anxieties that my parents have exhibited over the years, about someone marrying a Protestant or putting their mortal soul in jeopardy by converting from Catholicism to Protestantism or by leaving the Church altogether, or reading a child a children's Bible from the wrong denomination, or even of teaching Marxist literary theory, show the legacy of concerns left to them by their parents who were born in the late nineteenth and early twentieth century. Most people in my generation do not have those same concerns. The ProtestantCatholic divide has lost its sting in a largely secular age. My own students often do not know the difference, even if their families come from Christian traditions. They are a far cry from my parents' generation whose very identity was defined by their 
faith, a faith that was so tied into the ethnic identity of their parents' and grandparents' generations as they tried to make their families accepted in this country.

All ethnicities and the stories they tell about their group formation are works in progress. The Irish-American narrative is still being written, and Irish-American ethnic formation is still happening. The literature involved in this study provides a snapshot of how Irish-American authors thought about their communities from just after World War II to the beginning of the twenty-first century. Put together with Roddy Doyle's take on the creation of John Ford's The Quiet Man, that classic of Irish-American nostalgia for Ireland, these texts give insights into how Irishness has been performed and remembered in the United States. Most of the works discussed here have garnered little critical attention over the years. There are a few published articles on each, and coverage of the books by McSorley, Doyle Curran, and Cullinan in Charles Fanning's The Irish Voice in America. They have not been put together in this way before, in an attempt to trace the development of the Irish-American narrative over the last century, given that McSorley's and Doyle Curran's novels cast their glance back a few decades. Roddy Doyle's The Dead Republic has not, before this, been read alongside literature of Irish-American ethnic communities, and yet it is a story of how Irish Americans construct their picture of Ireland. In sum, the works studied here, put in conversation with each other and with Irish-American histories of the same time period, as well as with theories of nation, trauma, memory and forgetting, should get readers thinking about what has made it in and what has been left out of the Irish-American narrative, and what tensions, desires, and anxieties drove its creation. It is a fascinating story, gaps and all. 


\section{BIBLIOGRAPHY}

Anderson, Benedict. Imagined Communities: Reflections on the Origin and Spread of Nationalism. 1983. Revised Edition. Verso, 1991.

Appadurai, Arjun. Modernity at Large: Cultural Dimensions of Globalization. U of Minnesota P, 1996.

Aquinas, Thomas. "Of Mercy." The Summa Theologica. Translated by Fathers of the English Dominican Province, II.II, Question 30, http://www.documentacatholicaomnia.eu/03d/1225-

1274,_Thomas_Aquinas,_Summa_Theologiae_\%5B1\%5D,_EN.pdf. Accessed 19 March, 2017.

Armstrong, Karen. "How Not to Talk About God: An Interview with Karen Armstrong." US Catholic, vol. 75, no. 1, January 2010, pp. 24-28, http://www.uscatholic.org/node/5076. Accessed 19 March, 2017.

Barry, Dan. Pull Me Up: A Memoir. Norton, 2004.

Barry, Sebastian. On Canaan's Side. Penguin, 2011.

Bhabha, Homi K. The Location of Culture. Routledge, 1994.

---. Nation and Narration. Routledge, 1990.

Blaine, Angeline Kearns. I Used to Be Irish: Leaving Ireland, Becoming American. A\&A Farmar, Ltd., 2009.

Brothers, Doris. "Traumatic Attachments: Intergenerational Trauma, Dissociation, and the Analytic Relationship." International Journal of Psychoanalytic Self Psychology, vol. 9, no. 1, 2014, pp. 3-15, DOI:

$10.1080 / 15551024.2014 .857746$. 
Caruth, Cathy. Unclaimed Experienced: Trauma, Narrative, and History. Johns Hopkins UP, 1996.

Chakrabarty, Dipesh. Provincializing Europe: Postcolonial Thought and Historical Difference. Princeton UP, 2000.

Cheah, Pheng. Spectral Nationality: Passages of Freedom from Kant to Postcolonial Literatures of Liberation. Columbia UP, 2003.

Clark, Dennis. "The New York Irish: The Newsletter of the New York Irish History Roundtable.” Edited by Susan Neill. 1986 Edition, pp. 6+11.

Conboy, Sheila C. "Birth and Death: Female Tradition and the Narrative Voice in Mary Doyle Curran's The Parish and The Hill. MELUS, vol. 18, no. 1, IrishAmerican Literature, Spring 2003, pp. 61-69. JSTOR, www.jstor.org/stable/468103.

Connelly, Bridget. Forgetting Ireland: Uncovering a Family's Secret History. Borealis Books, 2003.

Conzen, Kathleen Neils, et al. "The Invention of Ethnicity: A Perspective from the USA.” American Immigration and Ethnicity, edited by David A. Gerber and Alan M. Kraut, Palgrave MacMillan, 2005, pp. 85-98.

Cullinan, Elizabeth. A Change of Scene. Norton, 1982.

---. House of Gold. Houghton Mifflin, 1970.

---. The Time of Adam. Houghton Mifflin, 1971.

---. Yellow Roses. Viking, 1977.

Curran, Joseph M. Hibernian Green and the Silver Screen: The Irish and American Movies. Praeger, 1989. 
Curran, Mary Doyle. The Parish and the Hill. 1948. The Feminist Press, 1986.

Deane, Seamus. A Short History of Irish Literature. Hutchinson, 1986.

“Death of John Laverty.” Obituary. Worcester Daily Spy. 24 April, 1886.

deMan, Paul. "Autobiography as De-facement." Comparative Literature, vol. 94, no.

5, Dec. 1979, pp. 919-930. JSTOR, doi: 10.2307/2906560.

Doyle, Roddy. The Dead Republic. Viking, 2010.

"Ending the Era of Harmful 'Indian' Mascots." National Congress of American Indians, n.d., www.ncai.org/proudtobe. Accessed 20 March 2017.

Erll, Astrid and Ansgar Nünning, editors. A Companion to Cultural Memory Studies. De Gruyter Publishers, 2010.

Fanning, Charles. The Irish Voice in America: 250 Years of Irish-American Fiction. $2^{\text {nd }}$ edition, The U.P. of Kentucky, 2000.

Fanon, Frantz. Black Skin, White Masks. 1952. Translated by Charles Lam Markmann, Grove P, 1967.

---. The Wretched of the Earth. 1961. Translated by Richard Philcox, Grove P, 2004. Ford, John, Dir. The Quiet Man. Argosy Pictures. 1952.

Franco, Dean J. "Introduction.” Race, Rights, and Recognition: Jewish American Literature Since 1969, Cornell UP, 2012. Project Muse, 20 Sept. 2016. muse.jhu.edu/book/24210. pp. 1-25.

Frazier, Adrian. Hollywood Irish: John Ford, Abbey Actors and the Irish Revival in Hollywood. Lilliput Press, 2010. 
Freud, Sigmund. "Remembering, Repeating and Working-Through.” Translated by Joan Riviere, 1924. The Standard Edition of the Complete Works of Sigmund Freud, vol. 12, edited by James Strachey, Hogarth Press, 1958, pp. 145-156.

Gellner, Ernest. Nations and Nationalism. Blackwell Publishing, 1983.

Gerber, David A. and Alan M. Kraut, Editors. American Immigration and Ethnicity. Palgrave MacMillan, 2005.

Gibbons, Luke. The Quiet Man (from Ireland into Film Series edited by Keith Hopper and Grainne Humphreys ). Cork UP, 2002.

Gilroy, Paul. The Black Atlantic. Harvard UP, 1993.

George, Rosemary Marangoly. The Politics of Home: Postcolonial Relocations and Twentieth-Century Fiction. U of California P, 1999.

Groome, Thomas H. What Makes Us Catholic? Eight Gifts for Life. Harper Collins, 2003.

Halbwachs, Maurice. On Collective Memory. 1952. Edited and translated by Lewis A. Coser, U of Chicago P, 1992.

Hallissy, Margaret. Reading Irish-American Fiction: The Hyphenated Self. Palgrave Macmillan, 2006.

Hayden, Tom. Irish on the Inside: In Search of the Soul of Irish America. Verso, 2001.

Hirsch, Marianne. "The Generation of Postmemory.” Poetics Today, vol. 29, no. 1, 2008, pp. 103-128. DOI: 10.1215/03335372-2007-019.

---. The Generation of Postmemory: Writing and Visual Culture After the Holocaust. Columbia UP, 2012. 
---. "Maternity and Rememory: Toni Morrison's Beloved." Representations of Motherhood, edited by Donna Bassin, Margaret Honey, and Meryle Mahrer Kaplan, Yale UP, 1994, pp. 92-110.

---. The Mother/Daughter Plot: Narrative, Psychoanalysis, Feminism. Indian UP, 1989.

---. "Mourning and Postmemory." Graphic Subjects: Critical Essays on Autobiography and Graphic Novels, edited by Michael A. Chaney, U of Wisconsin P, 2011, pp. 17-44. Project Muse, muse.jhu.edu/book/2457.

---. "Past Lives: Postmemories in Exile." Poetics Today, vol. 17, no. 4, Winter, 1996, pp. 659-686. JSTOR, www.jstor.org/stable/1773218.

Hirsch, Marianne and Valerie Smith. "Feminism and Cultural Memory: An Introduction." Signs, vol. 28, no. 1, Autumn 2002. JSTOR, www.jstor.org/stable/10.1086/340890.

Huntington, Samuel P. Who Are We? The Challenges to America's National Identity. Simon \& Schuster, 2004.

Ignatiev, Noel. How the Irish Became White. Routledge, 1995.

Kelly, Mary C. The Shamrock and the Lily: The New York Irish and the Creation of a Transatlantic Identity, 1845-1921. Peter Lang, 2005.

---. Ireland's Great Famine in Irish-American History: Enshrining a Fateful Memory. Rowman and Littlefield, 2014.

Kennedy, Eileen. “Bequeathing Tokens: Elizabeth Cullinan's Irish-Americans.” ÉireIreland, vol. 16, no. 4, 1981, pp. 94-102.

Kenny, Kevin. The American Irish: A History. Pearson Education Ltd., 2000. 
---. Diaspora: A Very Short Introduction. Oxford UP, 2013.

---. “Labor and Labor Organizations.” Lee and Casey, pp. 354-363.

---. "Race, Violence, and Anti-Irish Sentiment in the Nineteenth Century." Lee and Casey, pp. 364-378.

Kiberd, Declan. Inventing Ireland: The Literature of the Modern Nation. Harvard UP, 1995.

Lee, J.J. "Interpreting Irish America." Introduction. Lee and Casey, pp. 1-60.

Lee, J.J. and Marion R. Casey, editors. Making the Irish American: History and Heritage of the Irish in the United States. New York UP, 2006

Lloyd, David. Anomalous States: Irish Writing and the Post-Colonial Moment. Duke UP, 1993.

---. Irish Times: Temporalities of Modernity. Field Day, 2008.

Lukács, Georg. The Historical Novel. 1937. Translated by Hannah Mitchell and Stanley Mitchell, U of Nebraska P, 1983.

MacDonald, Michael Patrick. All Souls: A Family Story from Southie. Beacon P, 1999.

---. Easter Rising. Houghton Mifflin, 2006.

McCann, Colum. TransAtlantic. Random House, 2013.

McCourt, Frank. Angela's Ashes. Simon \& Schuster, 1996.

McInerney, Kathleen. “ ‘Forget about Being Irish': Family, Transgression, and Identity in the Fiction of Elizabeth Cullinan." Too Smart to Be Sentimental: Contemporary Irish American Women Writers, edited by Sally Barr Ebest, 
Kathleen McInerney, and Caledonia Kearns. U of Notre Dame P, 2008, pp.

97-115. Project MUSE, muse.jhu.edu/book/7349.

McSorley, Edward. Our Own Kind. Harper \& Brothers, 1946.

---. The Young McDermott. Harper \& Brothers, 1949.

Meagher, Timothy. Inventing Irish America. U of Notre Dame P, 2001.

---. “To Preserve the Flame.” Saint John's Church, Worcester, MA. 1984. https://drive.google.com/file/d/0B6NVPpaI0aEiS1lGUWhqeWJFY3c/view. 30 May 2016.

Murphy, Maureen. "Elizabeth Cullinan: Yellow and Gold" in Irish-American Fiction: Essays in Criticism, edited by Daniel J. Casey and Robert E. Rhodes. AMS Press, 1979, pp. 139-151.

Nash, Catherine. “'They're Family!’: Cultural Geographies of Relatedness in Popular Genealogy." Uprootings/Regroundings: Questions of Home and Migration, edited by Sara Ahmed, et al, Berg Publishers, 2004, pp. 179-203.

Neumann, Birgit. “The Literary Representation of Memory.” Erll and Nünning, pp. $333-343$

Ngũgĩ, wa Thiong'o. "The Language of African Literature." Decolonising the Mind, James Curry, Ltd., 1986, pp. 4-33.

Nietzsche, Friedrich. "On the Utility and Liability of History for Life." Unfashionable Observations. 1874. Translated by Richard T. Gray, Stanford UP, 1995, pp. $83-168$.

Nora, Pierre. Realms of Memory. 1992. Edited by Lawrence Kritzman, Translated by Arthur Goldhammer, Columbia UP, 1996. 
O'Connell, Shaun. "That Much Credit: Irish-American Identity and Writing." The Massachusetts Review: A Quarterly of Literature, the Arts and Public Affairs, vol. 44, no. 1-2, 2003, pp. 251-68. JSTOR, www.jstor.org.uri.idm.oclc.org/stable/25091939?origin=pubexport.

O'Connor, Edwin. The Last Hurrah, 1956 and The Edge of Sadness, 1961, published together by Little-Brown.

O’Connor, Thomas H. The Boston Irish: A Political History. Konecky \& Konecky, 1995.

“The Quiet Man.” IMDb (International Movie Database). 1990-2016. www.imdb.com/title/tt0045061/. Accessed 25 October 2016.

Quinn, Peter. Looking for Jimmy: A Search for Irish America. Overlook Press, 2007.

Ray, Sangeeta. En-Gendering India: Woman and Nation in Colonial and Postcolonial Narratives. Duke UP, 2000.

Renan, Ernest. "What is a Nation?" 1882. Translated by Martin Thom, Nation and Narration, edited by Homi K. Bhabha, Routledge, 1990, pp. 8-22.

Ricoeur, Paul. Memory, History, Forgetting. Translated by Kathleen Blamey and David Pellauer, U of Chicago P, 2004.

Rodgers, Mary Ann. "Re: john laverty obit." Received by the author. 2 June, 2015. Roediger, David. The Wages of Whiteness: Race and the Making of the American Working Class, Revised Edition, Verso, 1991, 1999.

Rogers, James Silas. Irish-American Autobiography: The Divided Hearts of Athletes, Priests, Pilgrims, and More. The Catholic U of America P, 2016. 
---, Editor. Extended Family: Essays on Being Irish American from New Hibernia Review. Dufour Editions, 2013.

Rothberg, Michael. Multidirectional Memory: Remembering the Holocaust in the Age of Decolonization. Stanford UP, 2009.

Rushdie, Salman. "Imaginary Homelands." 1982. Imaginary Homelands: Essays and Criticism, 1981-1991. Granta, 1991, pp. 9-21.

Saunders, Max. "Life-Writing, Cultural Memory, and Literary Studies.” Erll and Nünning, pp. 321-331.

Schwab, Gabriele. Haunting Legacies: Violent Histories and Transgenerational Trauma. Columbia UP, 2010.

Schwartz, Richard C. Internal Family Systems Therapy. The Guilford Press, 1995. Spivak, Gayatri Chakravorty. An Aesthetic Education in the Era of Globalization. Harvard UP, 2012.

Stack, Liam. "Debunking a Myth: The Irish Were Not Slaves, Too." The New York Times, 17 March, 2017, mobile.nytimes.com/2017/03/17/us/irish-slavesmyth.html?_r=0\&referer=https://m.facebook.com/. Accessed 19 March, 2017.

Stiegler, Bernard. Technics and Time, 1: The Fault of Epimetheus. 1994. Translated by Richard Beardsworth and George Collins, Standford UP, 1998.

Wall, Eamonn. “The Black Hills, The Gorey Road.” Rogers, Extended Family, pp. 204-225.

Walsh, Maurice. "The Quiet Man.” The New Frontier: John Wayne Internet Database. Originally printed in The Saturday Evening Post. 1933. dukefanclub.weebly.com/uploads/1/0/9/9/10994017/the_quiet_man.pdf. 
Accessed 25 October 2016.

Weinberg, Daniel E. "Viewing the Immigrant Experience in America through Fiction and Autobiography." The History Teacher, vol. 9, no. 3, May 1976, pp. 409432. JSTOR, www.jstor.org/stable/492334. 